\title{
Brachiopoda and Ostracoda of the
}

Cobleskill Limestone (Upper Silurian) of Central New York GEOLOGICAL SURVEY PROFESSIONAL PAPER 730 


\section{Brachiopoda and Ostracoda of the}

Cobleskill Limestone (Upper

\section{Silurian) of Central New York}

By JEAN M. BERDAN

GEOLOGICAL SURVEY PROFESIONAL PAPER 730

Descriptions and illustrations of 12 species of

brachiopods (including one new species) and

25 species of ostracodes (including four new

genera and 14 new species)

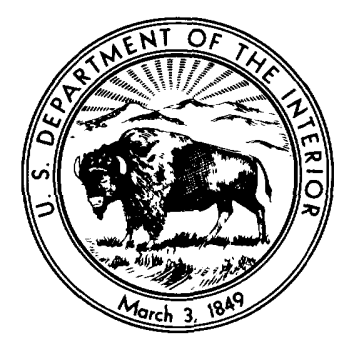

UNITED STATES GOVERNMENT PRINTING OFFICE, WASHINGTON : 1972 
UNITED STATES DEPARTMENT OF THE INTERIOR

ROGERS G. B. MORTON, Secretary

GEOLOGIGAL SURVEY

V. E. McKelvey, Director

Library of Congress catalog-card No. 70-189150

For sale by the Superintendent of Documents, U.S. Government Printing Office Washington, D.C. 20402 - Price $\$ 1$ (paper cover)

Stock Number 2401-2056 


\section{CONTENTS}

Abstract

Introduction

Previous work

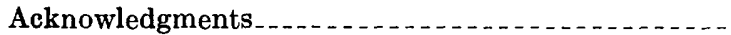

Scope of the report

List of localities

Paleoecology

Age and correlation

Systematic paleontology

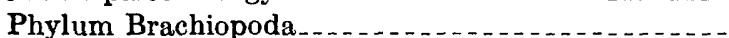

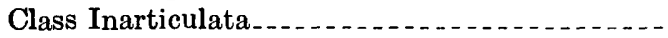

Genus Craniops Hall .............

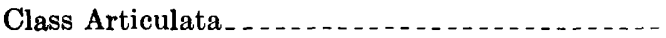
Genus Leptostrophia Hall and Clarke_Genus Morinorhynchus Havlíček...... Genus Eccentricosta Berdan......... Genus Machaeraria Cooper......... Genus Microsphaeridiorhynchus Sartenaer............................ Genus Lanceomyonia Havliček Genus Protathyris Kozlowski......... Genus Howellella Kozlowski..........

Phylum Arthropoda..........

Class Crustacea.....

Subclass Ostracoda. . . . . . . . . . .

Genus Leperditia Rouault...........

Genus Garniella Martinsson..........

Genus Migmatella n. gen..............

Genus Dibolbina Ulrich and Bassler.-

\begin{tabular}{r|} 
Page \\
1 \\
1 \\
1 \\
3 \\
3 \\
5 \\
6 \\
8 \\
9 \\
10 \\
10 \\
10 \\
10 \\
10 \\
11 \\
12 \\
13 \\
14 \\
15 \\
16 \\
18 \\
21 \\
21 \\
21 \\
21 \\
22 \\
22 \\
23
\end{tabular}

Systematic paleontology-Continued Phyllum Arthropoda-Continued

Class Crustacea-Continued

Subclass Ostracoda-Continued

Genus Hammariella Martinsson..... 24

Genus Kloedeniopsis n. gen.......... 24

Genus Tikiopsis n. gen............ 27

Genus Welleriopsis Swartz and Whit-

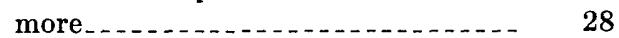

Kirkbyellid?, gen. and sp. indet..... $\quad 29$

Hollinid?, gen. and sp. indet........ 29

Genus Leiocyamus Martinsson ....... $\quad 29$

Genus Primitiopsis Jones............ 30

Genus Halliella Ulrich............. 30

Genus Dizygopleura Ulrich and Bassler _ $\quad 31$

Genus Kloedenella Ulrich and Bassler.- $\quad 37$

Genus Eukloedenella Ulrich and Bassler..................... 37

Genus Marginia Polenova_........ 38

Genus Bonneprimites Swartz and Whitmore

Genus Thlipsuropsis Swartz and Whitmore

Genus Thlipsurella Swartz_....... $\quad 39$

Genus Cytherellina Jones and Holl_... $\quad 39$

Genus Nunculina n. gen.......... 40

References cited...... 41

Index. . .

\section{ILLUSTRATIONS}

[Plates follow index]

Plate 1. Morinorhynchus?, Craniops, Eccentricosta, and Leptostrophia.

2. Lanceomyonia?, Machaeraria?, Microsphaeridiorhynchus, Protathyris, and Howellella.

3. "Kloedenia," Kloedeniopsis, Welleriopsis?, Tikiopsis, and Leperditia.

4. Hammariella, Garniella, Migmatella, and Dibolbina.

b. Dizygopleura.

6. Thlipsurella, Thlipsuropsis, Nunculina, hollinid?, kirkbyellid?, Halliella?, Marginia?, Cytherellina, Eukloedenella?, Bonneprimites?, Leiocyamus, Kloedenella, and Primitiopsis?. 
Figure 1. Index map showing generalized outcrop belt of Cobleskill Limestone and approximately equivalent formations in New York State showing

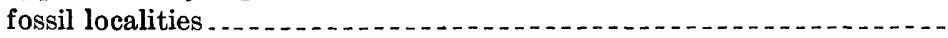
2-5. Diagrams showing:

2. Nine transverse sections of Lanceomyonia? dunbari n. sp........

3. Twelve transverse sections of Protathyris sulcata

4. Twelve transverse sections of Protathyris nucleolata

5. Inferred cross sections of three groups of North American beyrichiaceans. . .

6. Scatter diagram showing lengtb versus height of Dizygopleura hallii......

7. Scatter diagram showing length versus height of Dizygopleura monostigma

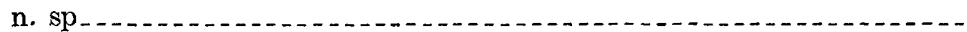

8. Drawing showing interior of left valve of Cytherellina crepiduloides n. sp.

9. Drawings showing transverse sections of Nunculina striatopuncta n. sp.-.

\section{TABLE}

TABLE 1. Distribution of brachiopods and ostracodes from the Cobleskill Limestone (Upper Silurian) of central New York 


\section{BRACHIOPODA AND OSTRACODA OF THE COBLESKILL LIMESTONE (UPPER SILURIAN) OF CENTRAL NEW YORK}

By JeAN M. BerdaN

\begin{abstract}
The Cobleskill Limestone is a thin unit that extends across New York from the westernmost part of Albany County on the east to Seneca County on the west. It is considered to be not younger than latest Silurian (Pridolí) in age, largely because it contains the coral Cystihalysites. The fauna belong to the Eccentricosta Zone of the Appalachians, known elsewhere in West Virginia, Virginia, Maryland, Pennsylvania, New Jersey, eastern New York, and Maine. Twelve brachiopods are described and illustrated, of which one species is new. Twenty-five ostracodes are also described and illustrated, of which four genera and 14 species are new. Kloedeniopsis $n$. gen. includes some of the ostracodes formerly called Kloedenia in North America. Three ostracode genera-Garniella, Hammariella, Leiocyamuspreviously known only from the Baltic province in Europe are reported from North America for the first time.
\end{abstract}

\section{INTRODUCTION}

The Cobleskill Limestone is the youngest fossiliferous formation of unquestioned Silurian age in central New York, and as such, its fauna, though small, is of exceptional interest. It is a thin unit which extends from West Township in Albany County (Goldring, 1935, p. 78) on the east to Seneca Falls in Seneca County on the west, a distance of about 130 miles. According to Rickard $(1962$, p. 26), its maximum thickness is about 15 feet, but at the type locality near Cobleskill Creek, along the road between Braymansville and Howes Cave in Schoharie County, it is only 9 feet thick. In the eastern part of the outcrop belt the Cobleskill rests unconformably upon the Brayman Shale of Silurian age (Rickard, 1962, p. 26), but west of Deck in Herkimer County the Oxbow Dolomite of Late Silurian age appears beneath it. Throughout its extent the Cobleskill is overlain by the Chrysler Limestone of Silurian and Devonian age.

Lithologically the Cobleskill varies from an impure crinoidal limestone to a fine-grained dark-gray aphanitic limestone to buff-colored or drab dolomite. Limestone is more common in the eastern part of the outcrop belt, although even in Schoharie County it tends to be dolomitic. West of Clockville in Madison County the for- mation is largely dolomite (Rickard, 1962, p. 26) except for an area of limestone at Aurelius Station, Frontenac Island, and Seneca Falls in Cayuga County. Fossils are most abundant in the limestone, and especially in the crinoidal limestone, which is commonly associated with biostromal beds of corals.

\section{PREVIOUS WORK}

The stratigraphy of the Cobleskill Limestone has been more thoroughly studied than its fauna, probably in part because the dolomitic nature of the rock makes it difficult to extract satisfactory specimens of fossils, and in part because the more dolomitic parts of the formation have very few fossils. Hall (1852, p. 321-322) called it the "coralline limestone" and described it as "*** a thin mass of limestone, characterized by an immense number of corals, chiefly favosites *** which forms a band so distinct from any other limestone that it has been for many years known by this name." He considered it the eastern extension of the Niagara (Lockport) Limestone of Middle Silurian age, but recognized that the fauna was not exactly the same and so described and illustrated the fossils separately (Hall, 1852, p. 322-338, pls. 72-78). According to Hartnagel (1903, p. 1113-1114), Clarke (in Merrill, 1902, p. r42) was the first to use the name Cobleskill for the "coralline limestone" of Hall and other geologists, but he did not discuss the formation or designate a type section. The most thorough stratigraphic study of the Cobleskill was made by Hartnagel (1903), who demonstrated for the first time that the Cobleskill was not the equivalent of the Lockport, but considerably younger, and published lists of fossils from the Cobleskill at 12 localities in Schoharie County and three localities in the vicinity of Union Springs in Cayuga County.

Grabau (1906, p. 104-111) redescribed the Cobleskill Limestone in the Schoharie and Cobleskill areas, and illustrated the more common fossils. In addition, local details of the stratigraphy and descriptions of lo- 
BRACHIOPODA AND OSTRACODA OF COBLESKILL LIMESTONE, CENTRAL NEW YORK

calities are given in New York State Museum Bulletins for the following quadrangles: Auburn-Genoa (Luther, 1910), Skaneateles (Smith, 1935), Tully (Clarke and Luther, 1905), Syracuse (Hopkins, 1914), Richfield Springs (Rickard and Zenger, 1964), and Berne (Goldring, 1935).

Recently, Rickard (1962, p. 23-27) has redescribed and redefined the type section of the Cobleskill at Howes Cave and described its occurrence and lithology across the State from Schoharie County to Seneca Falls, Seneca County, the westernmost exposure of undoubted Cobleskill. Rickard subdivided the Cobleskill at its type section into two parts, a lower massive unit and an upper, thin-bedded, more fossiliferous unit. In the upper unit, he included fossiliferous beds as high as a break 9 feet above the base of the formation. This redescription increases its thickness over the 6 feet given by Grabau (1906, p. 106) and includes all the markedly fossiliferous beds there in the Cobleskill.

The fauna of the Cobleskill has not been described as a unit since Hall (1852, p. 322-338, pls. 72-78) described and illustrated 30 species, all from Schoharie, N.Y. Of these 30 species, three were corals, two stromatoporoids, nine brachiopods, five pelecypods, six gastropods, three cephalopods, one trilobite, and one ostracode. Hartnagel (1903, p. 1126-1128) listed, but did not describe, 60 species for Schoharie County as a whole. These were grouped as follows: five corals; two stromatoporoids, one form identified as Chaetetes, which may be either a favositid coral or a bryozoan ; four bryozoans; one crinoid ; 12 brachiopods; eight pelecypods; six gastropods ; nine cephalopods; two worms not including Tentaculites; six trilobites; and four ostracodes, two of which were lumped as "Beyrichia, 2 species." Grabau (1906, p. $317)$ added one horn coral to Hartnagel's list, to make a total of 61 species.

Hartnagel (1903, p. 1132-1133) also listed 30 species from the Cobleskill at Frontenac Island, in Cayuga Lake off Union Springs. Of these 30 species, 16 also appear in the list for Schoharie County. However, four and a possible fifth, are species normally confined to the Manlius Limestone of Eearly Devonian age in other parts of the State; as indicated previously (Berdan, 1964 , p. B10-B11), these specimens were probably either from a mixed collection or were misidentified, as they have not been found elsewhere in the Cobleskill nor have they been found in later collections from Frontenac Island. In addition, four of the other 10 species listed by Hartnagel for this locality also occur in the Akron Dolomite (Upper Silurian) of the Buffalo area.

Flower $(1947$, p. $252 ; 1948$, p. 6-7) described two new species of cephalopods from the Cobleskill at Schoharie, N.Y., listed the cephalopod genera $(1947$, p. 250) and indicated (1948, p. 3-4) that the trochoceroids described by Hall (1852) as Trochoceras gebhardii and T. turbinata should be reassigned to Mitroceras and Foersteoceras, respectively.

The only ostracode described originally as coming from the Cobleskill is Leperditia jonesi Hall, 1859, which is believed to be a junior synonym of $L$. scalaris (Jones, 1858a, b). The latter is probably from the Bertie Limestone (Upper Silurian) at Williamsville, N.Y. However, at least one species, Dizygopleura hallii (Jones, 1890), which has been listed by Bassler and Kellett $(1934$, p. 66) and Warthin $(1937$, card 58) as coming from the Manlius Limestone (Lower Devonian), actually comes from the Cobleskill, as indicated by fossils on the same slab as the holotype (BMNH In 35128) in the British Museum (Natural History) collections. The holotype of Dizygopleura clarkei (Jones, 1892), here considered a junior synonym of $D$. hallii, also comes from the Cobleskill as discussed on page 33 .

Howell (1947) described two new "varieties" of spiriferid brachiopods, Howellella vanuxemi hartnageli and $H$. octocostata humilis, from the Cobleskill Limestone of the Schoharie area and Frontenac Island. $\mathrm{He}$ also identified several Cobleskill specimens as Howellella keyserensis (Swartz, 1923). The types of Howell's varieties have not been examined, but his illustrations (Howell, 1947, pl. 2) show them to be more coarsely plicate than any of the specimens studied for the present report.

In addition to papers directly concerned with the Cobleskill on a stratigraphic or paleontologic basis, there are several reports on related formations in which fossils are described which also occur in the Cobleskill. To the west, Grabau (1900, p. 363-373) discussed, described and illustrated the fauna of the "Manlius Limestone," now the Akron Dolomite (Upper Silurian), of Erie County, N.Y.; he listed 12 species from the Akron-one plant, one coral, six brachiopods, two gastropods, one cephalopod, and one ostracode. Although he noted the similarity of this fauna to that of the "Coralline limestone" in the eastern part of the state (Grabau, 1900, p. 352), he failed to recognize that this suggested an equivalence in age (Berdan, 1964, p. $\mathrm{B} 6-\mathrm{B} 7)$, a possibility which was left for Hartnagel (1903, p. 1138-1141) to discuss.

To the southeast, Weller (1903) described the fauna of the Decker Limestone (Upper Silurian) of New Jersey, which contains several species that also occur in the Cobleskill. He listed 48 species from the Decker, from the following groups: six corals, three bryozoans, 20 brachiopods, six pelecypods, five trilobites, and eight ostracodes. Weller $(1903$, p. 74$)$ noted that 32 of the 48 species had not been described except from the Decker; of the remain- 
ing 16 species, six are characteristic of the Cobleskill, and most of the other species are either long ranging or doubtfully identified. He therefore concluded that the Decker and Cobleskill should be correlated.

Swartz and Whitmore (1956, p. 1039-1041) described and illustrated 17 species of ostracodes and one brachiopod from the Decker Limestone in the Nearpass section on Wallpack Ridge, in northern New Jersey.

Recently, Hoar and Bowen (1967) discussed the stratigraphy of the Rondout (Upper Silurian and Lower Devonian) of the Hudson Valley and described from it 14 brachiopods, one coral, and one bryozoan. The Rondout, as revised by Rickard (1962, p. 29-31), includes beds equivalent to the Cobleskill in the Hudson Valley, and many of the brachiopods described by Hoar and Bowen (1967) also occur in the type Cobleskill.

\section{ACKNOWLEDGMENTS}

This study was begun under the guidance of Prof. C. O. Dunbar of Yale University, whose advice and assistance is gratefully acknowledged. I am deeply indebted to the following for the loan of type specimens and various other assistance: Dr. Rousseau H. Flower and the late Dr. Winifred Goldring, formerly of the New York State Museum; Drs. John G. Broughton, Donald W. Fisher, and Lawrence V. Rickard, and Mr. Clinton F. Kilfoyle of the New York State Museum and Science Service; Mr. Meredith Johnson, former state geologist of New Jersey; and Dr. G. Arthur Cooper and the late Dr. R. S. Bassler of the U.S. National Museum. Especial thanks are due Prof. F. M. Swartz of Pennsylvania State University, who generously made his ostracode collection available for study. W. A. Oliver, Jr., of the U.S. Geological Survey, kindly provided locality data and samples from localities not visited by me.

The writer is particularly grateful to Mr. R. M. Logie, who not only gave permission for the study of his collections, but also made available his field notebooks, sections, and unpublished manuscript.

In conclusion, I would like to thank my assistants, especially Mrs. Marija Balanc, who patiently tolerated tedious hours of picking and preparing ostracodes.

\section{SCOPE OF THE REPORT}

This report is based on part of a dissertation submitted for the degree of Doctor of Philosophy at Yale in 1949. The original manuscript described fossils from the Manlius Limestone as well as from the Cobleskill Limestone; these fossils were obtained from collections made by R. M. Logie during the summers of 1931-33. Logie, as a graduate student at Yale, had studied the stratigraphy of the "Manlius Group" of Clarke and Luther (1905), which included the Cobleskill, Chrysler, and
Manlius Limestones. His unpublished manuscript, notes, and collections were used in the preparation of the present report. The Chrysler Limestone, which lies between the Cobleskill and the Manlius, is virtually unfossiliferous. The faunal studies of the original dissertation were therefore concerned with the latter two limestones. It soon became apparent that whereas some of the collections considered Manlius by Logie strongly resembled the Coeymans Limestone (Lower Devonian) in both lithology and fauna, the Cobleskill fauna differed markedly from both the typical Manlius and the Coeymans (Berdan, 1964, p. B15-B16). Rickard (1962), by detailed stratigraphic tracing, has demonstrated that the Manlius and Coeymans interfinger, and therefore it seems obvious that the Manlius and Coeymans faunas should be studied together. Hence it has seemed desirable to extract the descriptions of the Cobleskill fossils and present them as a separate unit.

Work was concentrated on the brachiopods and ostracodes because these groups are among the more abundant elements of the fauna, both in number of species and in number of individuals. Also, in general, they are the best preserved. The next most important group is probably the corals, which are reasonably well preserved at some localities but tend to be spotty in their distribution. Although the number of coral species is not great, they are being studied by W. A. Oliver, Jr., because the association is quite interesting. Gastropods and pelecypods are rather common, but almost always poorly preserved. Cephalopods and trilobites are scarce, and good specimens are rare. Bryozoa, tentaculites, and stromatoporoids are present but unstudied. Conodonts are also present but undescribed.

In the dissertation as originally submitted, 11 species of brachiopods and 12 of ostracodes were described and illustrated. In this report, the number has risen to 12 species of brachiopods and 25 of ostracodes. Although this change is due in part to the increasing specialization in ostracodes on the part of the author, it is also due to the difficuity of collecting a complete sample of a fauna composed of microfossils. Whereas it is unlikely that many more species of brachiopods will be found in the Cobleskill, it is certain that additional ostracodes will be found in the future. Tantalizing fragments of undescribed species turn up in almost every new collection.

Most of the brachiopods from the Cobleskill have been previously described by Hall $(1852,1859)$, Vanuxem (1842), Grabau (1900), Weller $(1900,1903)$, and Schuchert (1903a), but these fossils are currently reassigned to other genera (Berdan, 1964, p. B15; Hoar and Bowen, 1967; Bowen, 1967). The brachiopods described herein do not include Atrypa "reticularis" and Leptaena 
"rhomboidalis," both of which were reported by Hartnagel (1903, p. 1126-1127) from the Cobleskill of Schoharie County, because they were not found in the collections studied for the present report. In contrast, only seven of the 25 taxa of ostracodes included in this paper have been previously described; and of these seven species, five have not been previously reported from the Cobleskill. This discrepancy may reflect the lack of adequate microscopes and specialists in the early years of the century when most of the taxonomic work was done on the fossils from this formation. Hartnagel and others recognized the abundance of ostracodes in the Cobleskill but lacked the equipment and background to describe them.

This report is based on collections from the Cobleskill outcrop belt from 12 localities extending from the Seneca Falls $71 / 2$-minute quadrangle in the west to the Schoharie 71/2-minute quadrangle in the east. These localities are shown in figure 1 . Collections were made at seven of these localities by R. M. Logie, and these were prepared and studied in the laboratory by me. The most fossiliferous localities as indicated by Logie's collections were re-collected, and four additional localities were visited and collections made. The westernmost locality, at Seneca Falls, has not been seen by me, but material collected by W. A. Oliver, Jr., has been studied. The places from which collections were made are described in the "List of localities" (p. 5), and collection numbers are given to indicate how many collections were made from each locality. The geographic distribution of described species is shown in table 1. The collections generally were not made with stratigraphic control within the Cobleskill Limestone because the formation is thin, and at most localities the section is not complete. However, to judge from places where most of the formation is exposed, the fauna does not appear to change vertically.

Although the Cobleskill Limestone is fairly fossilif-

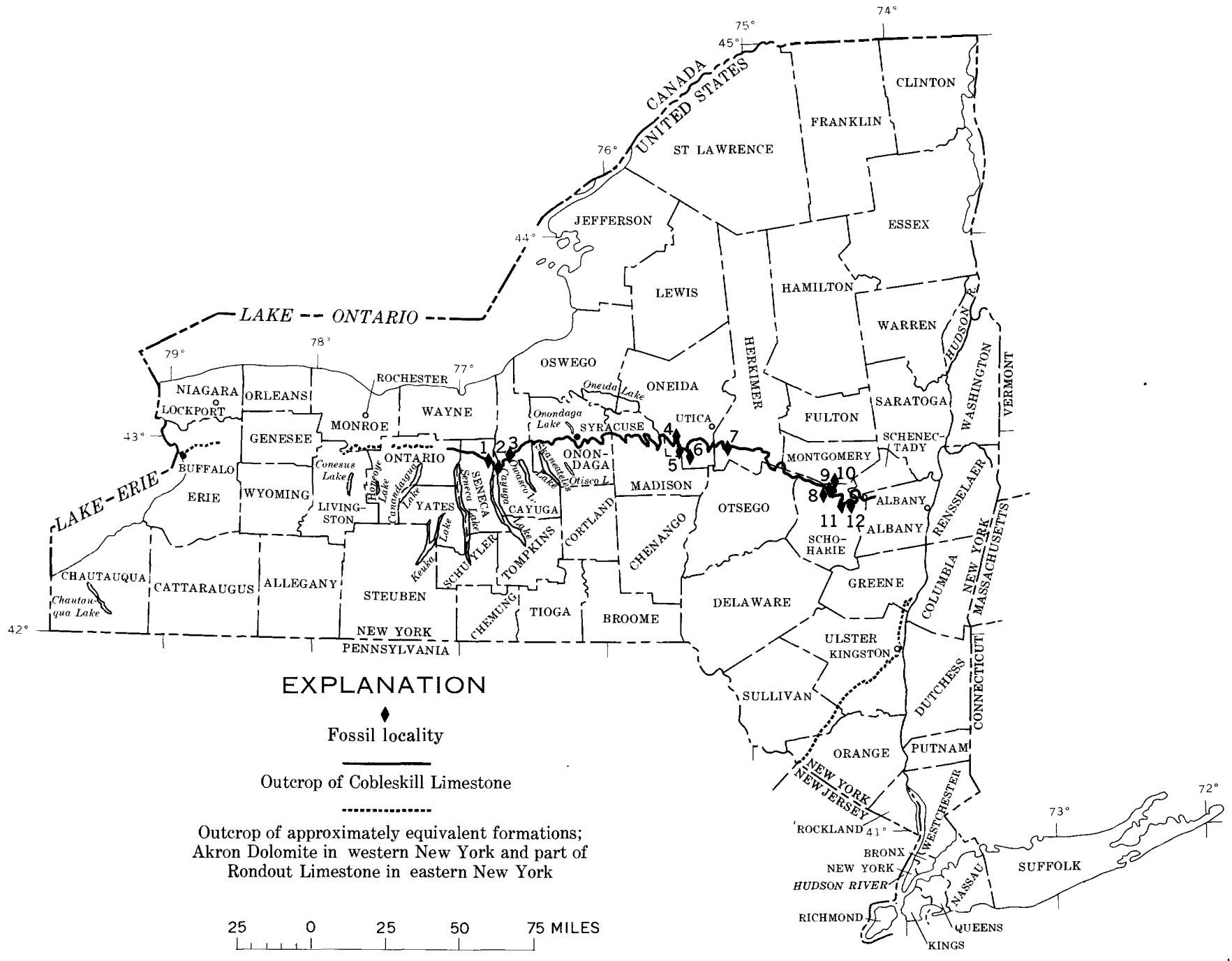

FIgURE 1.-Generalized outcrop belt of Cobleskill Limestone and approximately equivalent formations in New York State showing fossil localities. Modified from Rickard (1969, pl. 10). 
erous, it is difficult to extract good specimens. Much of the limestone is aphanitic and breaks through rather than around the fossils, and in the more dolomitic parts of the formation the fossils are generally poorly preserved. Only one locality (fig. 1, loc. 3, Aurelius Station, USGS 3395-SD) has been found where the brachiopods are partially silicified, and here the ostracodes are so poorly silicified that they cannot be determined from residues, although excellent specimens may be broken out of the rock. Most of the brachiopods and many of the ostracodes were prepared mechanically with rock nippers, needles, and vibratools. However, one locality, at Spring Street, Schoharie (fig. 1, loc. 11), has yielded free specimens, and most of the illustrated ostracodes have come from this place. Many of these species have been found at other localities, and as those that occur elsewhere usually are the most abundant species in the Schoharie collections, it seems reasonable to assume that the association of ostracodes at Schoharie is representative of the Cobleskill at other localities across the State, even though the less common species may have been found only at Schoharie. Two collections were originally made from Schoharie by Logie, and because of the ease of preparing the ostracodes from this locality five additional collections from here were made by me at later dates.

Because of the number and variety of ostracodes found at the Spring Street locality it seems desirable to discuss it more fully than possible in the "List of localities." According to R. M. Logie's field notes, dated September 7, 1932, this locality is the same as Brown's quarry, described by Hartnagel (1903, p. 1120-1121) and Grabau (1906, p. 106-107, 236-237) as being a quarter of a mile southeast of the Schoharie Post Office, in the hollow between the cemetery and the noad leading east from the post office. Hartnagel (1903, p. 1120) listed the fossils from this locality and mentioned that the faunas from the different layers vary somewhat. In 1932, Logie described the collections he made as coming from the north edge of the road and just below it, a quarter of a mile east of the Schoharie Post Office, Cromer's place. He noted that there was hardly any vestige of quarrying left, and the spot is no longer called "Brown's quarry," that name being used for another quarry. By 1946, the post office had been moved to the northern end of the village of Schoharie, so that the earlier locality descriptions are no longer applicable. Collections made by me in 1950 (USGS 3393-SD), 1964 (USGS 7283-SD), 1967 (USGS 8062SD, USGS 8063-SD), and 1968 (USGS 8439-SD) were all from ledges and the dirt beneath them on the south side of the road; that is, not precisely the same spot as R. M. Logie's collections. One collection made in 1967 (USGS 8064-SD) was made from the north side of the road. By 1967 the section was very badly overgrown, and some of the outcrops on the north side of the road had been covered by bulldozing for a small dam. The Brayman Shale (Upper Silurian)-reported by Hartnagel (1903), Grabau (1906), and Logie-is apparently no longer exposed.

Hartnagel (1903, p. 1121) described three units at this locality that he considered to belong to the Cobleskill, as follows: 3 feet, 10 inches of limestone at the base, 1 foot, 4 inches of limestone (marble layer), and 10 inches of thin-bedded, somewhat arenaceous limestone. It is difficult now to recognize here any of these subdivisions. USGS collection 8063-SD may have come from Hartnagel's "marble layer," as it was obtained from a highly crinoidal limestone and the dirt just beneath it. On the other hand, Logie's original collection YPM 5244/146 may have come from the thin sandy layers at the top of the Cobleskill which Hartnagel (1903) stated to have abundant Machaeraria? lamellata, as that species is abundant in Logie's collection. These thin sandy layers are apparently no longer exposed, although the overlying Chrysler Limestone is exposed in ledges farther up the road.

Ostracodes from the various collections from this locality were obtained primarily by boiling, washing, and picking the dirt, but a few were extracted mechanically. Specimens in the rock are commonly better preserved than those in the dirt, especially with regard to fine surface ornamentation, and thus they supplement the more abundant but slightly corroded free specimens. It should be noted that the free specimens are commonly somewhat compressed or crushed; thus, although an effort was made to select only uncrushed specimens for measurement, there may be an element of error, especially in the measurements of height.

Examination of specimens in the bedrock is also a useful check against the dirt collections that might have been contaminated by material from higher formations. Dirt from collection USGS 8062-SD was found to contain silicified ostracodes from the overlying Coeymans and Kalkberg Limestones as well as specimens from the Cobleskill. Described specimens from this collection were extracted from rock.

\section{LIST OF LOCALITIES}

The following fossil localities are shown in figure 1.

1. Abandoned quarry just north of house at end of private road at and just southwest of the city limits of Seneca Falls, Seneca Falls 71/2-minute quadrangle, Seneca County. USGS 6084-SD, W. A. Oliver, Jr., collector. McQuan's quarry of Hartnagel (1903,p. 1137). 
2. Frontenac Island, in Cayuga Lake west of Union Springs, from southeast end of island, Stromatopora beds, Union Springs 71/2-minute quadrangle, Cayuga County. USGS 3389-SD, J. M. Berdan collector. See Hartnagel (1903, p. 11301134).

3. About 0.6 of a mile east of Aurelius Station on New York Route 326, Cayuga 71/2-minute quadrangle, Cayuga County. YPM 5244/1.56, R. M. Logie collector; YPM 5244/14, R. M. Logie collector; USGS 3395-SD, north side of Route 326 , J. M. Berdan collector.

4. Prospect Hill, at base of microwave tower, 2.7 miles airline west of Franklin Springs, Clinton $71 / 2^{-}$ minute quadrangle, Oneida County. USGS 5207SD, J. M. Berdan collector.

5. Roadcut about 1 mile north of Oriskany Falls on Route 12B, Oriskany Falls 71/2-minute quadrangle, Oneida County. YPM 5244/88, R. M. Logie collector.

6. Cut on side road to west and above New York State Route 315, 0.5 mile south of Forge Hollow, Oriskany Falls 71/2-minute quadrangle, Oneida County. YPM 5244/90, R. M. Logie collector.

7. In the hillside on the southwest side of highway, above crossroads 1.1 miles southeast of Jerusalem Hill crossroads, West Winfield $71 / 2$-minute quadrangle, Herkimer County. YPM 5244/108, R. M. Logie collector. This locality is probably near YPM 2594, C. E. Beecher collector, from "Jerusalem Hill, N.Y." See Hartnagel (1903, p. 1167$1169)$.

8. About 200 feet west of the village of Howes Cave on north side of road between Howes Cave and Braymanville, Cobleskill 71/2-minute quadrangle, Schoharie County. Type section of Cobleskill. USGS 8065-SD, J. M. Berdan collector. About 4 feet below top of formation. See Hartnagel (1903, p. 1114-1115, 1124), Grabau (1906, p. 106) and Rickard (1962, p. 23).

9. At head of the shorter of the two streams between Central Bridge and Howes Cave, Schoharie 71/2minute quadrangle, Schoharie County. YPM 5244/143, R. M. Logie collector. See Hartnagel (1903, p. 1124-1125) and Grabau (1906, p. 106).

10. Ledges in pasture near dirt road branching off to north from road between Central Bridge and Howes Cave, 1.5 miles west-southwest of Central Bridge, Schoharie 71/2-minute quadrangle, Schoharie County. USGS 7198-SD, J. M. Berdan collector. See Hartnagel (1903, p. 1125).

11. Spring Street, Schoharie, N.Y.; first terrace going east up hill before fork in road, about 800 feet east of intersection with main street, across hollow south of St. Paul's Cemetery, Schoharie 71/2minute quadrangle, Schoharie County. YPM $5244 / 146$, on the north edge of the road and just below it, Cromer's place, R. M. Logie collector; YPM 5244/147, 400-500 feet south of Spring Street, R. M. Logie collector; USGS 3393-SD, south side of Spring Street, J. M. Berdan collector; USGS 7283-SD, dirt under ledges on south side of Spring Street, J. M. Berdan collector; USGS 8062-SD, dirt and thin-bedded limestone, south side of Spring Street, about 15-17 feet above top of small dam north of road, J. M. Berdan collector; USGS 8063-SD and USGS 8439$\mathrm{SD}$, crinoidal limestone and dirt beneath it, south side of Spring Street about 12 feet above top of dam, J. M. Berdan collector; USGS 8064-SD, about same level, north side of Spring Street, J. M. Berdan collector. See Hartnagel (1903, p. 1120-1121) and Grabau (1906, p. 106, 236-237). 12. About one-third of a mile southwest of Shutter Corners, Schoharie 71/2-minute quadrangle, Schoharie County. YPM 5244/150, R. M. Logie collector. Also about 0.4 of a mile south of Shutter Corners, ledges in pasture south of road, Schoharie $71 / 2$-minute quadrangle. USGS $3390-S D$, J. M. Berdan collector. See Hartnagel (1903, p. 1116-1119) and Grabau (1906, p. 107).

\section{PALEOECOLOGY}

As this report was designed primarily as a systematic study of two groups of Cobleskill fossils, it is not possible to make firmly based statements about the overall paleoecology of the fauna. However, some observations concerming fossil occurrences may be made and some tentative conclusions drawn from them. As indicated in figure 1 , the fossils studied came from three general areas in the Cobleskill outcrop belt: (1) A western area near the north end of Cayuga Lake, (2) a central area south and west of Utica, and (3) an eastern area in Schoharie County. Table 1 shows the occurrences of species at the localities in these areas, arranged from west to east. Table 1 indicates certain differences between the western and eastern assemblages; for example, Protathyris sulcata has not been found in any of the eastern collections, apparently being replaced by Protathyris nucleolata, and Machaeraria? lamellata has not been found in the western collections. On the other hand, Eccentricosta jerseyensis is found in the eastern and central collections, and although not found in recent collections from the western localities, it was reported by Hartnagel (1903, p. 1133) from Frontenac Island. It seems probable that the differences in distribution of 
some of the brachiopods and ostracodes were due to differences in the paleoenvironment, rather than to deposition of the Cobleskill as a time-transgressive formation.

The Cobleskill in the western area contains biostromes that are largely composed of stromatoporoids together with associated horn corals. Nonbiostromal beds are of two types: hard dark-blue-gray aphanitic limestone, which breaks with a conchoidal fracture and softer drab buff-weathering thin-bedded magnesian limestone. At Aurelius Station (fig. 1, loc. 3), Protathyris sulcata and Leperditia scalaris are most abundant in the aphanitic limestone, and Microsphaeridiorhynchus litchfieldensis and Howellella are more common in the drab buffweathering beds. Both ostracodes and brachiopods occur in interstices of the biostromal beds, but are commonly broken and difficult to identify. There is some indication, however, that Protathyris nucleolata tends to replace $P$. sulcata in the biostromes. The association of $P$. sulcata, Leperditia scalaris, and Kloedeniopsis hartnageli in aphanitic limestone is found as far east as Forge Hollow (fig. 1, loc. 6) but has not been found in the easternmost exposures of Cobleskill.

Biostromal beds are apparently lacking in the central group of localities, and the Cobleskill in this area tends to be more dolomitic than it is either to the east or west. The collection from Oriskany Falls (fig. 1, loc. 5) is of interest because although the ubiquitous ostracodes Leperditia scalaris and Kloedeniopsis hartnageli are present, they are associated with small gastropods rather than with brachiopods. Otherwise the faunal associations in this area seem to be intermediate between those to the west and those to the east.

The eastern localities, like the western localities, have biostromal beds but the type of biostrome is different. At Shutter Corners (fig. 1, loc. 12) and west of Central Bridge (fig. 1, loc. 10), the biostromes are largely composed of colonial corals, rather than stromatoporoids.

TABLE 1.-Distribution of brachiopods and ostracodes from the Cobleskill Limestone (Upper Silurian) of central New York [Locality numbers refer to those in fig. 1 and in the "List of Localities"]

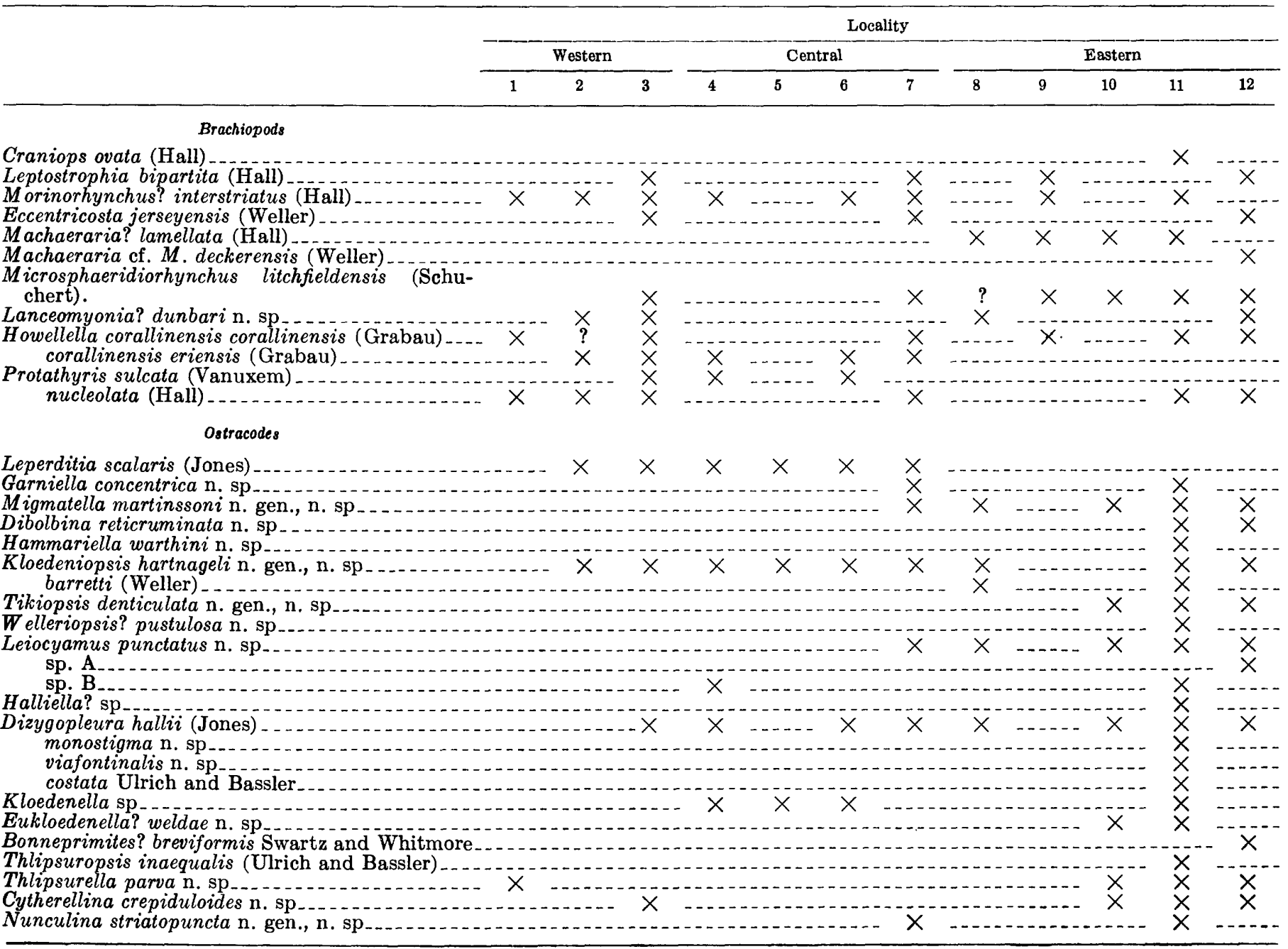


and may have been responsible for Hall's (1852) name of "Coralline limestone" for the Cobleskill. In addition, at these and other localities, especially Spring Street at Schoharie (fig. 1, loc. 11), the Cobleskill contains considerable amounts of pelmatozoan debris, especially pieces of stem which may be $1 \mathrm{~cm}$ long or longer. Some beds are largely composed of this material and could be considered "crinoidal" limestone, but in others the pelmatozoan debris is sparsely and randomly distributed in a fine-grained matrix, as at the type section of the Cobleskill at Howes Cave (fig. 1, loc. 8). At first glance, the more "crinoidal" beds might be taken for calcareous sands deposited in a high-energy environment; but the presence of unbroken pieces of pelmatozoan stem, complete brachiopods and complete carapaces of ostracodes, together with fine-grained matrix in the interstices of even the most "crinoidal" rock, suggests that these beds represent plantations of crinoids or cystoids which disintegrated in place and were only slightly winnowed by wave or current action. Hyman (1955, p. 117-118) has discussed the relationship of various small crustaceans with living crinoids, and although none of those she mentioned were ostracodes, it seems possible that some of the large ostracodes found in the Cobleskill, such as Tikiopsis denticulata, may have been associated with the pelmatozoans, as they appear to be restricted to the beds of pelmatozoan debris.

Hoar and Bowen (1967, p. 10-13) and Harper (1968) have described the facies changes and discussed the paleoenvironment of the Rondout Formation of the Hudson Valley, part of which is the temporal equivalent of the Cobleskill Limestone. They have suggested that the thin-bedded dolomitic facies was deposited on subaerially exposed mudflats behind reefs and banks which developed parallel to a north-south-trending shoreline not far to the east. The reefs and banks are now represented by a limestone facies containing corals and stromatoporoids. The amount of limestone in the formation increases to the southwest, away from the shoreline, and is greatest in the vicinity of Accord (Port Jackson). According to Goldring (1935, p. 78), the easternmost exposure of the Cobleskill, east of West Township, contains stromatoporoids. This locality is nearly due north of Accord, and might suggest a facies similar to that of the Glasco Member of the Rondout at Accord, with implied similar depth of water and distance from shore. The localities near Schoharie, on the other hand, contain coral biostromes and beds of pelmatozoan debris and suggest slightly deeper water. The more dolomitic central localities and the western stromatoporoid biostromes may indicate a shoaling toward the west. The general picture, therefore, is of a broad, shallow sea or bay with a slightly asymmetric bottom profile, being slightly deeper to the east. The presence of pelmatozoans and corals suggests that the salinity on the reefs and banks was nearly that of normal sea water and that circulation was not restricted. It is not certain whether the absence of the Cobleskill east of West Township is due to nondeposition on a shallow bar, or erosion prior to deposition of the Thacher Member of the Manlius Limestone, but the stromatoporoid beds at West Township suggest the latter.

\section{AGE AND CORRELATION}

The Cobleskill Limestone of Central New York is generally considered to be the stratigraphic equivalent of the lower part of the Rondout Limestone of eastern New York, the Decker Limestone of New Jersey, and the Eccentricosta Zone of the Keyser Limestone of Pennsylvania, Maryland, and West Virginia (Rickard, 1962; Berdan, 1964). Weller (1903, p. 74-75) noted that Barrett (1878) was the first to recognize the similarity between fossils in what is now the Decker Limestone at the Nearpass quarries in northern New Jersey and those from the "Coralline limestone" at Schoharie. Schuchert (1903a, p. 417) commented on the resemblance of his "Manlius" formation in Maryland, which would be the lower part of the Keyser, to the "Coralline limestone" in central New York. Hartnagel (1903) discussed the position of the Cobleskill equivalent in the Hudson Valley. Although there is little question about the general equivalence of the Eccentricosta Zone in the Appalachians, details still remain to be worked out. For example, Hartnagel (1903, p. 1141-1152) considered the "Middle ledge" of the cement miners in the Hudson Valley, now the Glasco Member of the Rondout Limestone, to be the Cobleskill equivalent, and so called it Cobleskill in his paper. Hoar and Bowen (1967, p. 14), however, believe the Cobleskill to be the equivalent of the Wilbur, Rosendale, and Glasco Membersnot just the Glasco. Whether the Cobleskill represents all or only part of the Eccentricosta Zone will have to be determined by a more detailed study of all groups of fossils within it as related to measured sections.

Recently Hoar and Bowen (1967, p. 15-17) and Bowen (1967, p. 11-16) have summarized the evidence of the brachiopods for general correlations, and have provided range charts for the Rondout and Keyser, respectively. To date, the ranges of ostracodes in the Keyser, Decker, and Rondout are too poorly known to make them useful for any precise correlation. Ulrich and Bassler (1913) described 29 species of the Keyser ostracodes of which 12 are from the Eccentricosta Zone, but ranges within the zone are not well defined, and even random sampling indicates that there are many 
more species to be described. Weller (1903, p. 252-257) described eight species (one based on a female of one of his other species) from the Decker at the Nearpass section, New Jersey, most of which came from the top 5 feet of the formation. Swartz and Whitmore (1956) added to the ostracode fauna from the same locality by describing 10 new species, all but three of which also came from the upper part of the formation. The ostracodes of the Rondout are undescribed. Of the described ostracodes from the Keyser and Decker, only four have been found in the Cobleskill; these are Kloedeniopsis barretti, Dizygopleura costata, Bonneprimites? breviformis, and Thlipsuropsis inaequatis. In addition, Leperditia scalaris from the Cobleskill has been reported from the Decker.

The few ostracodes in common between the Cobleskill and the Decker and Keyser might be interpreted as due either to differences in facies, or to lack of exact contemporaneity, or to both. Further detailed collecting through measured sections may help to determine which ostracodes are controlled by facies and which are widespread, short ranging, and therefore useful biostratigraphically. The need for such collecting is shown by a random sample from the Decker at Shawnee on Delaware, Pa. (USGS collection 6060-SD), which contains Dizygopleura costata, Leiocyamus sp., and Migmatella sp.-all forms that have not previously been known from the Decker and that are the same as or close to species from the Cobleskill. This collection also contains Limbinaria? muricata (Ulrich and Bassler, 1923), a distinctive ostracode that occurs at the top of the Tonoloway Limestone (Upper Silurian) and in the base of the Keyser in Maryland, in the Wilbur Member of the Rondout in the Hudson Valley, and also in the Hardwood Mountain Formation (Upper Silurian) in Maine, but has not as yet been found in the Cobleskill. The Hardwood Mountain also contains a species of the brachiopod Eccentricosta and the ostracodes Dibolbina sp. and Dizygopleura sp. aff. D. costata, which suggests that it may be close to the Cobleskill in age, although some of its other ostracodes would indicate that it is slightly older.

Hartnagel (1903, p. 1138-1141) correlated the "Bullhead" limestone (now Akron Dolomite) of the Buffalo region in western New York with the Cobleskill Limestone of central New York on the basis of the fauna described by Grabau (1900). Rickard (1962, p. 25) has reviewed the literature on the Akron, and concluded that the relationship between it and the Cobleskill is as yet uncertain. However, the resemblance between the Akron fauna as described by Grabau (1900) and that of the Cobleskill is so strong that it would seem that the burden of proof would be on those who sug- gest that the two formations are not equivalent. In particular, the presence of Protathyris sulcata and the cephalopod Mitroceras gebhardii (Hall, 1852) in both formations seems most suggestive. However, the fauna of the Akron should be restudied to confirm the identifications and to determine whether any additional species can be found. Other than Leperditia scalaris, no ostracodes have been reported from the Akron, but because of the dolomitic character of the rock they may not have been preserved.

A. J. Boucot (written commun., 1967) has remarked that the brachiopods of the Eccentricosta Zone are endemic in character and camnot be directly correlated with the standard European section. The presence of Cystihalysites in the Cobleskill and other formations of this zone indicates that the Cobleskill is not younger than Silurian, and it has been considered by Berry and Boucot (1970, p. 33) to be Pridolí in age.

The larger beyrichiid ostracodes, like the brachiopods, seem to be endemic in character and restricted to the Appalachian faunal province, although a related genus, Welleriella Abushik, 1968, occurs in the Lower Devonian (Ivane horizon) of Podolia. However, it is interesting that among the smaller ostracodes there are three genera-Hammariella Martinsson, 1962, Garniella Martinsson, 1962, and Leiocyamus Martinsson, 1956-which have not previously been described from North America but which occur in the Baltic province. Perhaps eventually the ostracodes will be of more use in intercontinental correlation.

\section{SYSTEMATIC PALEONTOLOGY}

Suprageneric classification of the brachiopods in the present report is based on the "Treatise on Invertebrate Paleontology, Part H, Brachiopoda 1 and 2" edited by Moore (1965). Suprageneric classification of the ostracodes is based in part on the "Treatise on Invertebrate Paleontology, Part Q, Arthropoda 3" edited by Moore (1961), but the beyrichiid genera are classified according to Martinsson (1962).

The terms used herein for morphologic features of the brachiopods are largely those used in the "Treatise on Invertebrate Paleontology, Part H, Brachiopoda 1." Morphologic terminology for the ostracodes is based on the "Treatise on Invertebrate Paleontology, Part Q, Arthropoda 3," with the exception of terms used for the beyrichiids which follow those proposed by Martinsson (1962) and Henningsmoen (1965). The terminology used in Moore (1961) and that of Martinsson (1962) are not in conflict except for expressions referring to the lobation of beyrichiid valves. Note, for example, that the "preadductorial node" of Martinsson (1962, p. 64) corresponds to "L2" of Moore (1961), the "adductorial 
BRACHIOPODA AND OSTRACODA OF COBLESKILL LIMESTONE, CENTRAL NEW YORK

sulcus" of Martinsson is "S2" of Moore (1961), and so forth. Because Martinsson's terms have been widely employed by students of beyrichiids it has seemed desirable to use them here rather than to adhere to Moore's (1961) terminology for the sake of consistency.

Brachiopods were measured with vernier calipers, and ostracodes were measured with a micrometer ocular in a zoom microscope set at a factor of $\times 2$.

Abbreviations used for institutions from which collection or specimen numbers are cited are as follows: American Museum of Natural History, AMNH; British Museum (Natural History), BMNH; New York State Museum, NYSM ; U.S. Geological Survey, USGS ; U.S. National Museum, USNM; and Yale Peabody Museum, YPM.

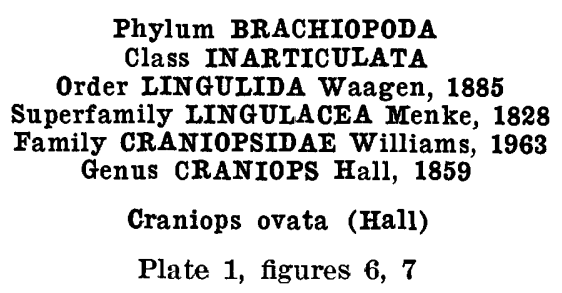

Pholidops ovatus Hall, 1859, p. 490, pl. 103-B, figs. 7a, b; Hall and Clarke, 1892 , p. 157, 159, pl. 4I, figs. 22, 23 ; Weller, 1903 , p. 226 , pl. 20 , figs. $27-29$, p. 300.

Pholidops ovata Hall. Schuchert in Schuchert and Maynard, 1913, p. 294, pl. 53, nigs. 10-12.

Description.--Shell biconvex; outline oval, apices eccentric along long axis of valves. Surface ornamented by as many as eight growth varices eccentric about apices. Pedicle valve more convex than brachial valve, internal pedicle valve has a muscle platform composed of two prominent calluses with a low depression between them, united anteriorly. Brachial valve has similar muscle platform but median depression is deeper and extends anteriorly so that platform may appear bilobate.

A wide valve (pl. 1, fig. 7) is $2.3 \mathrm{~mm}$ long and 2.0 $\mathrm{mm}$ wide. A narrower valve is $2.4 \mathrm{~mm}$ long and $2.0 \mathrm{~mm}$ wide.

Discussion.-Rowell (in Moore, 1965, p. H273) indicates that Craniops shows a scar of attachment on the pedicle valve. Schuchert (in Schuchert and Maynard, 1913, p. 294) described a "cementation scar" on the pedicle valve of Craniops ovata from the lower part of the Keyser Limestone in Maryland. The specimens from the Cobleskill here described are too poorly preserved to determine the presence or absence of this scar, as in most specimens the apex is eroded.

Craniops ovata was originally described by Hall $(1859$, p. 490) from the "shaly limestone of the Helderberg group" (New Scotland Limestone) in Albany County, N.Y. Although no specimens from the New
Scotland of Albany County were available for comparison, the Cobleskill specimens have been compared with specimens from the Kalkberg Limestone beneath the New Scotland at Schoharie, N.Y.; no significant differences were apparent.

Size of sample.-Ten single valves and five complete but crushed shells were available for study.

Occurrence.-All specimens of Craniops ovata studied from the Cobleskill came from collections from Schoharie, N.Y. (YPM 5244/146, USGS 3393-SD. USGS 7283-SD, USGS 8063-SD).

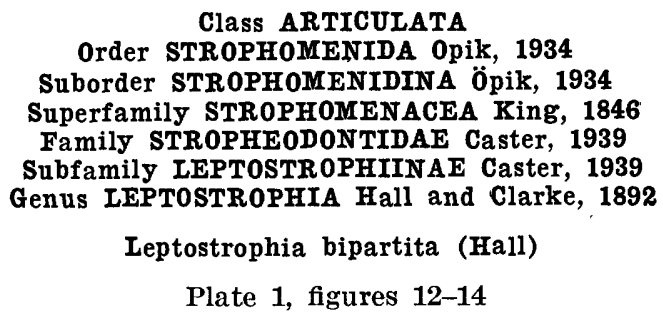

Leptaena bipartita Hall, 1852, p. 326, pl. 74, fig. 6.

Strophomena bipartita (Hall). Hall, 1859, p. 82.

Stropheodonta bipartita (Hall). Weller, 1903, p. 226, pl. 20, figs. 1-5.

Stropheodonta (Leptostrophia) bipartita (Hall). Schuchert, 1903b, p. 165; Maynard in Schuchert and Maynard, 1913 , p. 316 , pl. 57, figs. $17,18$.

Leptostrophia bipartita bipartita (Hall). Bowen, 1967, p. 31. Strophodonta textilis Hall, 1852, p. 327, pl. 74, fig. 6.

Stropheodonta (Leptostrophia) textilis (Hall). Hall and Clarke, 1892, p. 288.

Leptaena —, Hall, 1852, pl. 74, fig. 3.

Description.-Shell planoconvex; outline semielliptical, slightly wider than long. Hinge produced into blunt auricles; hingeline denticulate to two-thirds length from delthyrium. Cardinal area of pedicle valve relatively high; delthyrium not completely closed; lunate aperture between pseudodeltidium and chilidium.

Ornamentation consists of fine angular lirae crossed by closely spaced filae giving reticulate appearance. Lirae straight, nodose in many specimens, and warped around surface irregularities of shell; increase both by implantation and bifurcation, fasciculate in some specimens.

Pedicle valve has leptostrophiid diductor muscle scars bounded by strong posterolateral callus ridges. Dental lamellae lacking.

Brachial valve has large, erect cardinal process resting on tripartite callus platform. Lateral callus buttresses best developed parallel to hinge line, but fan forward to the adductor scars. Adductor scars feebly impressed and narrow; median buttress narrow and low. Two inconspicuous nodes on either side of and posterior 
to the cardinal process may represent socket plates. Chilidium large and covers base of cardinal process.

A representative specimen is $2.9 \mathrm{~cm}$ wide and 2.4 cm long. A smaller specimen is $1.8 \mathrm{~cm}$ wide and $1.7 \mathrm{~cm}$ long.

Discussion.-Hall (1852, p. 326-327) originally described two species, Leptaena bipartita and Strophodonta textilis, from the Cobleskill Limestone, the former on the basis of a poorly preserved pedicle interior and the latter from a specimen preserving some of the characteristic surface ornamentation described above. Subsequent work has shown that shells with the internal characters of Hall's Leptaena bipartita have the surface ornamentation of his Strophodonta textilis. Consequently the two names are considered synonymous, and the first has been used because it has page precedence.

Barrett (1878, p. 372) described Strophodonta nearpassi as comparable to the figures on Hall's (1852) plates and having the surface ormamentation of Strophodonta textilis. Prouty and Swartz (1923, p. 426-427) have used Barrett's name "nearpassi" as a varietal form of Leptostrophia bipartita for those shells in which the radial ornamentation is curved toward the hinge line, rather than being straight as in the types of Hall's species. Bowen (1967, p. 30-31) and Hoar and Bowen (1967, p. 19-20) consider Leptostrophia bipartita nearpassi a subspecies of Leptostrophia bipartita.

Unfortunately the material studied is mostly fragmentary and poorly preserved. The description of the interior of the brachial valve is based on a specimen of L. bipartita nearpassi (YPM 23795) from near Glenerie, in the Hudson Valley, as no well-preserved brachial interiors were available from central New York. One specimen of a pedicle valve from Schoharie was calcined to show the posterolateral ridges bounding the diductor scars. In this specimen, the posterolateral ridges subtend an angle of about $90^{\circ}$, whereas the type specimens in the New York State Museum at Albany indicate that the angle is about $60^{\circ}$. Whether the specimen from Schoharie is aberrant, or whether it represents a distinct species cannot be determined from the material at hand.

Size of sample.-More than 10 fragmentary specimens were available for study.

Occurrence.-Leptostrophia bipartita has been found in collections from Shutter Corners (YPM 5244/150, USGS 3390-SD), Howes Cave (YPM 5244/143), Jerusalem Hill (YPM 2594), Glenerie, N.Y. (YPM 5244/ 3.145), and Aurelius Station (YPM 5244/14), but does not appear to be common. Leptostrophia bipartita nearpassi occurs in beds of Late Silurian age from the Hudsö Valley, and has been reported from New Jersey
(Weller, 1903, p. 226), Maryland (Schuchert and Maynard, 1913, p. 316), Pennsylvania (Reeside, 1917, p. 201), and West Virginia and Virginia (Swartz, 1929, p. 35$)$.

\section{Superfamily DAVIDSONIACEA King, 1850 Family CHILIDIOPSIDAE Boucot, 1959 Genus MORINORHYNCHUS Havlicek, 1965 \\ Morinorhynchus? interstriatus (Hall) \\ Plate 1, figures 1-5}

Orthis interstriata Hall, 1852, p. 326, pl. 74, figs. 1, 2. Orthothetes interstriatus (Hall). Schuchert, 1897, p. 297; Weller, 1903 , p. 229 , pl. 20 , figs. 8,9 ; Schuchert, 1903, p. 165; Grabau, 1906, p. 109, fig. 8.

Schuchertella interstriata (Hall). Grabau and Shimer, 1909, p. 228, fig. 227; Grabau in Grabau and Sherzer, 1910, p. 121-123, pl. 17, figs. 4, 5, pl. 32, figs. 1a-c.

"Schellwienella" interstriata (Hall). Berdan, 1964, p. B15.

Orthothetes hydraulicus Whitfield. Grabau, 1900, p. 365, pl. 22, figs. 1 a-c; 1901, p. 184, fig. 92.

Description.-Shell planoconvex to weakly biconvex, semielliptical in outline; cardinal angles blunt or rounded; greatest width anterior to hingeline. Ventral interarea small, apsacline; dorsal interarea linear. Delthyrium nearly closed by convex pseudodeltidium; low perideltidial area extends about one-fourth of length from pseudodeltidium to cardinal angle. Notothyrium plugged by base of cardinal process; no chilidial plates seen. Pedicle beak relatively prominent; brachial beak very subdued.

Ornamentation consists of angular costellae curving toward posterolateral margins of shell and increasing by intercalation. Costellae crossed by fine filae.

Pedicle valve contains moderately prominent teeth supported by short dental lamellae that subtend an arc of about $65^{\circ}$. No muscle scars observed.

Brachial valve has small bilobed cardinal process to which relatively ponderous brachiophores are attached anterolaterally. Brachiophores connected to palintrope by horizontal socket plates (pl. 1, fig. 3). Shell thin; external ornamentation impressed on inner surfaces. No muscle scars observed.

Shell small. Figured specimen (pl. 1, fig. 2) is 0.85 of a cm long and $1.1 \mathrm{~cm}$ wide. A fragmentary specimen is $1.5 \mathrm{~cm}$ long and $2.0 \mathrm{~cm}$ wide.

Discussion.-This small planoconvex to concavoconvex species resembles Morinorhynchus dalmanelliformis Havlíček, 1965-the type species of Morinorhynchus-in having a convex pseudodeltidium, dental lamellae, and rounded cardinal angles. However, Havlíček (1965, p. 292) stated that Morinorhynchus has a well-developed dorsal interarea and discrete chilidial plates, and because $M$.? interstriata has a linear dorsal interarea and no chilidial plates have been ob- 
served, the species is only questionably assigned to Morinorhynchus. Havlíček (1967, p. 192) considered that Morinorhynchus was related to Fardenia Lamont, 1935. Fardenia was originally described as having an open delthyrium (Lamont, 1935, p. 310-311), but Boucot $(1959$, p. 26) and Havlíček $(1965$, p. 291) later stated that it has a small apical pseudodeltidium. Havlíček (1967,p. 192) further noted that the character of the brachiophores differs in the two genera. Thus there appears to be a valid distinction between the Late Ordovician-Early Silurian genus Fardenia and the Late Silurian genus Morinorhynchus.

The Keyser species Schuchertella prolifica Schuchert, 1913 , superficially resembles $M$ ? interstriata, except for its larger size, but lacks dental lamellae (Bowen, 1967, p. 28) and is not congeneric.

Size of sample.-Eleven specimens, many of which were fragmentary, were available for study.

Occurrence.-Morinorhynchus? interstriatus has been found in the Cobleskill in collections made from Schoharie (YPM 5244/146), between Central Bridge and Howes Cave (YPM 5244/143), at Jerusalem Hill (YPM 2594), near Forge Hollow (YPM 5244/90), at Prospect Hill (USGS 5207-SD), at Aurelius Station (YPM 5244/14), and at Seneca Falls (USGS 6084$\mathrm{SD})$. It is also found in the Akron Dolomite in the Buffalo area. It has been reported from New Jersey by Weller (1903, p. 229). Reeside $(1917$, p. 201$)$ tentatively identified it from the Keyser Limestone of Pennsylvania, but it does not seem to occur farther south.

\section{Suborder CHONETIDINA Muir-Wood, 1955 \\ Superfamily CHONETACEA Brown, 1862 \\ Family CHONETIDAE Brown, 1862 \\ Genus ECCENTRICOSTA Berdan, 1963}

Eccentricosta jerseyensis (Weller)

Plate 1, figures 8-11

Chonetes jerseyensis Weller, 1900, p. $8 ; 1903$, p. 230-231, pl. 20, figs. 11-16; Maynard in Schuchert and Maynard, 1913, p. 338, pl. 61, figs. 17-19.

Eccentricosta jerseyensis (Weller). Berdan, 1963, p. 254-256 ; Hoar and Bowen, 1967, p. 18-19; Bowen, 1967, p. 26-27.

Description.-Shell concavoconvex; depth of curvature about one-eighth length of shell. Outline semielliptical; maximum width about halfway between anterior and posterior margins, not at hinge. Cardinal angles rounded. Wider than long; length about twothirds width. Cardinal area relatively high; beaks of both valves low. Six to seven spines on each side of beak of pedicle valve, set perpendicular to hinge line; these increase in size toward posterolateral angles of shell.

Ornamentation consists of coarse subangular costae increasing both by implantation and bifurcation; in some specimens they anastomose. Costae curved toward anterior margin of shell, originating from point behind beak so that hinge line appears to cut them. Very fine filae cross radial ornament but are easily eroded and not visible on many specimens.

Pedicle valve contains short, thick, low median myophragm flanked on either side by two posterolateral ridges that presumably mark the posterior boundaries of the diductor muscle scars. Inner surface of valve costellate; costellae marked by impressions of papillae. Dental lamellae lacking.

Brachial valve contains small sessile bilobed cardinal process, each lobe projecting posteriorly, in contact with inner edge of other lobe, forming a small spoon-shaped structure. Cardinal process rests upon a low tripartite callus platform with short median buttress ; lateral buttresses form well-developed ridges that parallel the hinge line and bound the dental sockets anteriorly. Crural bases small, rest upon the lateral callus buttresses, and make an angle of about $30^{\circ}$ with the hinge line. Two thin myophragms extend about one-fifth of distance from hinge line to anterior margin. Muscle scars absent or ightly impressed, surface ornamentation visible on interior of valves.

A representative specimen is $1.2 \mathrm{~cm}$ long and $1.7 \mathrm{~cm}$ wide.

Discussion.-Eccentricosta jerseyensis is very abundant at some localities; and, paradoxically, it is difficult to find well-preserved specimens, for where it is present the species tends to occur in shell beds that contain many individuals, most of which are incomplete. Because of its distinctive ornamentation, however, the species can be recognized from small fragments of shell; this characteristic, combined with its restricted vertical range in the middle Appalachians, makes $E$. jerseyensis a useful guide fossil. Its presence in central New York, the type area of the Cobleskill Limestone, has been one of the chief reasons for correlating this formation with the Decker Limestone of New Jersey and the lower part of the Keyser Limestone of Maryland. Specimens from central New York seem to have somewhat more irregular costae than the type specimen. Specimens from Shutter Corners (USGS 3390-SD) were calcined, which showed that they have hollow cardinal spines.

Size of sample.-More than 15 specimens were available for study.

Occurrence.-This species has been found in collections from Shutter Corners (YPM. 5244/150, USGS 3390-SD), Jerusalem Hill (YPM 2594), and Aurelius Station (YPM 5244/14). In Pennsylvania and New Jersey it occurs through approximately 50 feet of limestone and sandstone (Swartz and Swartz, 1941, pl. 1), but in New York it is restricted to the Cobleskill Limestone, which has a maximum thickness of 15 feet. In 
Maryland and Virginia it is a zone fossil for the lower part of the Keyser Limestone (Bowen, 1967).

\section{Order RHYNCHONELIDA Kuhn, 1949 Superfamily RHYNCHONELLACEA Gray, 1848 Family RHYNCHOTREMATIDAE Schuchert, 1913 Subfamily ORTHORHYNCHULINAE Cooper, 1956 Genus MACHaERaria Cooper, 1955 \\ Machaeraria? lamellata (Hall)}

Plate 2, figures 9-16

Atrypa lamellata Hall, 1852, p. 329, pl. 74, fig. 11.

Atrypa? lamellata Hall. Weller, 1903, p. 237, pl. 21, figs. 23-29.

Rhynchonella lamellata (Hall). Hall, 1859, p. 78; Schuchert, 1897 , p. $359 ; 1903$, p. 167.

Camarotoechia lamellata (Hall). Grabau, 1906, p. 109, fig. 13 ; Grabau and Shimer, 1909, p. 286, fig. 349; Maynard in Schuchert and Maynard, 1913, p. 352, pl. 63, figs. 9, 10, Stenoschisma lamellata (Hall). Swartz, 1939, p. 84.

Machaeraria ? lamellata (Hall). Hoar and Bowen, 1967, p. 31-32.

Description.-Shell small, subquadrate in adults, subtrigonal to subcircular in young specimens. In adults, length about four-fifths width. Pedicle beak low, tightly curved over brachial beak, which penetrates delthyrium. Foramen apparently open. Brachial valve slightly more convex than pedicle valve, with prominent fold starting at about one-third of length of shell and greatly elevated anteriorly. Complementary sulcus on pedicle valve; anterior margin of pedicle valve produced as linguiform extension into fold.

Shell surface covered with angular plicae that extend from beak to anterior margin; three on fold, two in sulcus, and six to seven on each lateral slope. Plicae crossed by conspicuous concentric lamellae, present even on juvenile specimens, showing on abraded specimens as nodes on radial ornament.

Pedicle valve with thin dental lamellae enclosing angle of about $60^{\circ}$. Muscle scars too feebly impressed to be distinguishable.

Brachial valve with discrete cardinal plates separated by narrow trough containing thin, bladelike cardinal process. Posterolateral margins of cardinal plates project over deep, narrow dental sockets. Cardinal plates triangular, apparently bearing relatively long, curved crura. Low median ridge presumably divides muscle field, of which there is no other indication.

A representative specimen is 0.8 of a cm long, 0.9 of a $\mathrm{cm}$ wide, and 0.5 of a $\mathrm{cm}$ thick. Free brachial valve of large specimen (pl. 2, fig. 16) is 0.9 of a $\mathrm{cm}$ long and $1.1 \mathrm{~cm}$ wide.

Discussion.-This species becomes more transverse as it increases in size, developing from a small flat shell with a subcircular outline (pl. 2, fig. 9) into a subquadrate form in which the width is greater than the length. However, at all stages of growth it is marked by the prominent imbricating lamellae which give it its name. Machaeraria? lamellata is close to the type species of Machaeraria, $M$. formosa (Hall), in its possession of a divided hinge plate and a small linear cardinal process in the brachial valve, also in its transverse form and the structure of the pedicle valve. However, it apparently differs in lacking support plates under the crura.

Size of sample.-More than 25 specimens were available for study.

Occurrence.-Machaeraria? lamellata is common in collections from Schoharie (YPM 5244/146, USGS 3393-SD) and the vicinity of Howes Cave (USGS 8065-SD, YPM 5244/143, USGS 7198-SD) but has not been found in collections from farther west in New York, although it is associated with such species as Microsphaeridiorhynchus litchfieldensis and Howellella corallinensis that do occur in the western part of the State. It has been found in the Rondout Formation of eastern New York (Hoar and Bowen, 1967, p. 31-32) and the Decker Limestone of New Jersey (Weller, 1903, p. 237). M.? lamellata has also been reported from the Keyser Limestone of Pennsylvania, Maryland and Virginia and from the underlying Tonoloway Limestone, although Hoar and Bowen (1967, p. 31) noted that specimens from these formations differ from those in the Decker, Rondout, and Cobleskill in having only one plication in the sulcus and two on the fold.

\section{Machaeraria sp. cf. M. deckerensis (Weller)}

Rhynchonella deckerensis Weller, 1903, p. 234.

Stenoschisma deckerensis (Weller), Maynard in Schuchert and Maynard, 1913, p. 349.

Original description.-Shell subtriangular, wider than long, the posterolateral margins sloping from the beak, where they form an angle of from 95 to 115 degrees, in nearly straight lines to a point a little posterior to the middle of the shell ; the lateral and front margins regularly rounded. The pedicle valve is usually a little less convex than the opposite one; its beak is prominent, arched, but not strongly incurved; the sinus is rather abrupt, not reaching quite to the beak. The surface of the brachial valve curves gently to the margins, except toward the front, where the mesial fold is rather abruptly elevated. The surface of each valve is marked by from twenty to twenty-four simple, angular plications, of which two or three, somewhat coarser than the remainder, are depressed in the median sinus, with a corresponding number elevated in the fold of the brachial valve.

The dimensions of a rather large specimen are: length, $15 \mathrm{~mm}$; width, $19.5 \mathrm{~mm}$; thickness, $10 \mathrm{~mm}$ (Weller, 1903, p. 234). 
Discussion.-Several fragmentary and distorted specimens of a large rhynchonellid from Shutter Corners have been referred provisionally to this species because of their large size, transverse outline, and numerous angular plications. Serial sections of one of the less deformed shells showed that the cardinal plates were discrete and were separated by a trough containing a cardinal process, as in M. lamellata. None of the specimens was sufficiently well preserved to be suitable for illustration or positive identification. Only three specimens were found, all from the same locality, Shutter Corners, N.Y. (YPM 5244/150, USGS 3390-SD).

Family TRIGONIRHYNCHIIDAE McLaren, 1965 Genus MICROSPHAERIDIORHYNCHUS Sartenaer, 1970

Microsphaeridiorhynchus litchfieldensis (Schuchert)

Plate 2, figures 17-29

Rhynchonella? litch fieldensis Schuchert, 1903b, p. 167.

Camarotoechia litchfieldensis (Schuchert). Grabau, 1906, p. 109, fig. 14; Maynard (in Schuchert and Maynard), 1913, p. 353, pl. 63, figs. 11-14; Reeside, 1917, p. 201; Swartz, F. M., 1929, p. 36.

Cupularostrum? litchfieldensis (Schuchert). Hoar and Bowen, 1967, p. 27-28, pl. 2, figs. 26-31.

Cupularostrum litch fieldensis (Schuchert). Bowen, 1967, p. 5557, pl. 7, figs. 25, 26, 28-33.

Microsphaeridiorhynchus litchfieldensis (Schuchert). Sartenaer, 1970, p. 27-29.

Atrypa sp. Hall, 1852, p. 330, pl. 74, figs. 11, 12.

?Rhynchonella agglomerata Weller, 1903, p. 234-235, pl. 21, figs. 5-11.

Camarotoechia neglecta Hall. Hartnagel, 1903, p. 1128, 1150.

Description.-Shell small, subtrigonal to subpentagonal in outline, greatest width halfway between beak and anterior margin. Length and width nearly equal, length about nine-tenths width. Posterolateral slopes almost straight, making an angle of about $95^{\circ}$ with each other. Pedicle beak overhangs, and brachial beak penetrates delthyrium. Brachial valve slightly more convex than pedicle valve, with well-defined fold in anterior half of shell. Complementary sulcus in pedicle valve. Angular plicae extend from beaks to anterior and lateral margins of shell, covering entire surface except for very small areas on posterolateral slopes of pedicle valve. Normally four plicae on fold, three in sulcus, and six or seven on each lateral slope.

Brachial valve contains small septalium on median septum which extends about half length of shell. Cardinal plates tend to unite over crural cavity and form subpentagonal plate to inner face of which are attached slender, up-curved crura. Dental sockets small, noncrenulate, partly hidden by posterior sides of cardinal plates (pl. 2, fig. 17). Cardinal plates not completely fused, and are always discrete posteriorly, leaving opening into crural cavity.
Pedicle valve contains thin dental lamellae. Muscle scars too lightly impressed to be visible.

A representative specimen (pl. 2, figs. 22-25) is 0.82 of a cm long, 0.89 of a cm wide and 0.5 of a cm thick. A larger specimen is $1.1 \mathrm{~cm}$ long, $1.1 \mathrm{~cm}$ wide, and 0.7 of a cm thick. Fragmentary specimens indicate that the species grows larger, but none have been suitable for measurement.

Discussion.-Sartenaer (1970, p. 27-29) has recently designated Rhynchonella? litchfieldensis Schuchert, 1903, the type species of his new genus Microsphaeridiorhynchus, in which only the type species is included. $\mathrm{He}$ has removed this species from Cupularostrum Sartenaer, 1961, because, among other differences, the sockets are simple and not crenulated, and he considers it not to belong in Ancillotoechia Havlíček, 1959, because the ventral beak is less projecting and there is no median longitudinal crest on the anterior part of the plate over the septalium (Sartenaer, 1970, p. 28). $M$. litchfieldensis has a superficial resemblance to Iberirhynchia santaluciensis Drot and Westbroek, 1966, but as described by Drot and Westbroek (1966), Iberirhynchia has more massive internal structures in both valves. Schuchert (1903b, p. 167) originally described $M$. litchfieldensis as follows:

This species is one of a group represented in the Rochester shales by $R$. (?) neglecta and in the Helderbergian by $R$. (?) transversa. It differs from the former in having more plications with the fold and sinus narrower and less pronounced. It is more closely related to $R$. (?) transversa, but never attains the size of this species, nor is the fold and sinus so broad.

A form found with typical M. litchfieldensis in some collections is about half its size, subtrigonal in outline, and lacks a fold and sulcus. This may be the juvenile form of $M$. litchfieldensis, as the fold and sulcus are present on only the anterior half of mature specimens, and all other shell features of this form are consistent with this interpretation.

Size of sample.-More than eight specimens were available for study.

Occurrence.-Microsphaeridiorhynchus litchfieldensis was first described from the Cobleskill Limestone at Schoharie and has been found in collections YPM 5244/ 146, USGS 3393-SD, and several others. It has also been found in collections from Shutter Corners (YPM 5244/150), Howes Cave (USGS 8065-SD), Central Bridge (YPM 5244/143, USGS 7198-SD), Jerusalem Hill (YPM 2594), and Aurelius Station (YPM 5244/ 14). Hartnagel (1903, p. 1128) identified it as Camarotoechia neglecta and stated that it occurred in the Wilbur Member (Upper Silurian) of the Rondout in the Hudson Valley. It has also been reported from the Rosendale and Glasco Members of the Rondout in east- 
ern New York (Hoar and Bowen, 1967, p. 27-28), the Decker Limestone of New Jersey (Weller, 1903, p. 234), and the lower part of the Keyser Limestone in Pennsylvania (Reeside, 1917, p. 188, 190, 201), Maryland (Schuchert and Maynard, 1913, p. 353; Bowen, 1967, p. 55-57), and Virginia and West Virginia (Swartz, 1929 , p. 36). In Pennsylvania it is reported as also occurring in the Tonoloway Limestone.

\section{Family UNCINULIDAE Rzonsnitskaya, 1956 Genus LANCEOMYONIA Havlíček, 1960}

Lanceomyonia? dunbari n. sp.

Plate 2, figures 1-8; figure 2

Description.-Shell small, subpentagonal in outline; width and length about equal; thickness nearly threequarters of width. Pedicle valve shallow, with low sulcus in anterior third, and with linguiform projection into brachial valve at nearly right angle to posterior part of shell. Brachial valve inflated, with low fold corresponding to sulcus. Pedicle beak erect, exposing triangular delthyrium partly penetrated by brachial beak. Pseudoarea present, formed by break in slope between upper surface of umbonal region and concave ventral cardinal slopes. Anterior third of shell ornamented by low, rounded ribs with linear interspaces, three in sulcus, four on fold, and three or four on each lateral slope.

Pedicle valve contains short but well-developed dental lamellae, and low median carina which presumably divides muscle field. No other indications of muscle field observed.
Brachial valve contains small septalium. Posterolateral margins of hinge plates appear to extend as flanges over dental sockets. At anterior margin of septalium hinge plates form narrow bridge over crural cavity.

The holotype (pl. 2, figs. 5-8) is 0.8 of a $\mathrm{cm}$ in both length and width, and 0.6 of a $\mathrm{cm}$ in thickness.

Holotype.-YPM 23798.

Discussion.-This small species was originally thought to belong in Sphaerirhynchia Cooper and Muir-Wood, 1951, but differs from that genus in having ribs only on the anterior part of the shell. It appears to be closer to Lanceomyonia Havlíček, 1960, but differs from that genus in its small size, and in apparently possessing a small plate bridging the septalium (fig. 2). However, the only specimen available for sectioning was an immature individual, so the structure of the septalium cannot be stated with complete assurance. Because of the paucity of specimens, the species cannot as yet be assigned to a genus with assurance, and is only provisionally placed in Lanceomyonia.

An extremely inflated specimen (pl. 2, figs. 1-4), which is considerably smaller than the type, shows the two-cycle growth pattern considered diagnostic by $\mathrm{Hav}$ líček (1961, p. 110-111) of the subfamily Hebetoechiinae. This particular specimen may represent another species, or may be a dwarfed specimen of $L$.? dunbari; the material at hand is not adequate to determine which.

Size of sample.-This species is not common, the description being based on one complete specimen, the immature specimen, and several fragmentary individuals.

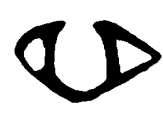

0.1

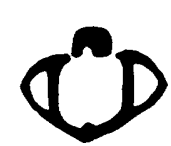

0.2

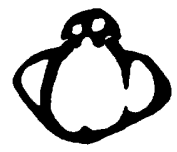

0.4

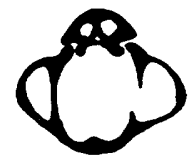

0.45

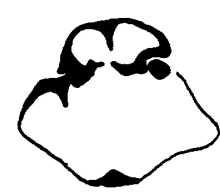

0.65

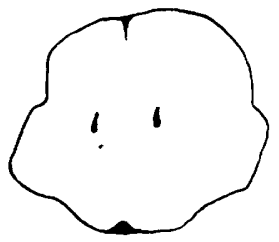

1.2

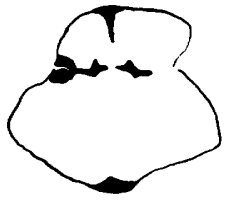

0.7

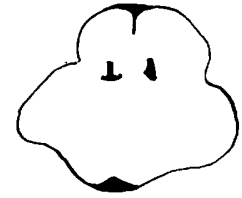

0.8

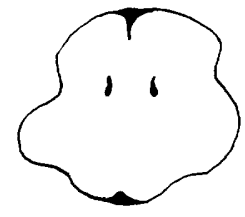

1.0
Figure 2.-Nine transverse sections of Lanceomyonia? dunbari $\mathrm{n}$. sp. Sections from beak toward anterior showing small cruralium, crura, and dental lamellae. Specimen from Aurelius Station (YPM colln. 5244/14). Length before sectioning $6.2 \mathrm{~mm}$; measurements in millimeters from pedicle valve beak. 
Several juvenile specimens have been found which are almost completely flat, lack a fold and sulcus, and have only faint plications on the anterior margins.

Occurrence.-The species is widely distributed and has been found in collections from Frontenac Island (USGS 3389-SD), Aurelius Station (YPM 5244/14), Howes Cave (USGS 8065-SD), and Shutter Corners (YPM 5244/150).

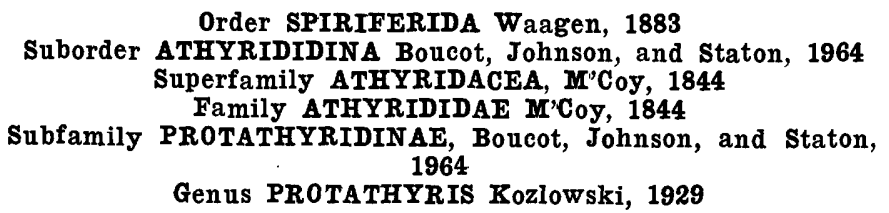

Order SPIRIFERIDA Waagen, 1883

Suborder ATHYRIDIDINA Boucot, Johnson, and Staton, 1964 Superfamily ATHYRIDACEA, M'Coy, 1844 Family ATHYRIDIDAE M'Coy, 1844

Subfamily PROTATHYRIDINAE, Boucot, Johnson, and Staton, 1964

Genus PROTATHYRIS Kozlowski, 1929

Protathyris sulcata (Vanuxem)

Plate 2, figures 30-35; figure 3

Atrypa sulcata Vanuxem, 1842, p. 112, fig. 5.

Merista sulcata (Vanuxem). Miller, 1877, p. 115.

Whitfieldella sulcata (Vanuxem). Grabau, 1900, p. 367, pl. 22, figs. 2a-d. Grabau, in Grabau and Sherzer, 1910, p. 156-157, pl. 32, figs. $2 a-d$.

Merista bisulcata Hall, 1859, p. 253.

Description.-Small, subovate in outline; width onehalf to three-quarters of length; both valves inflated. Height of both valves equal to or slightly greater than width, the posterior third being most inflated. Pedicle beak prominent, commonly curving over and concealing delthyrium. Brachial beak low, penetrates the delthyrium, which appears to be open. Both valves sulcate; pedicle valve with subangular sulcus extending from plane perpendicular to hinge line to anterior margin; brachial valve with linear depression extending from umbo to anterior margin.

Surface smooth except for concentric growth lines.

Pedicle valve contains thin, rather short dental lamellae. Muscle scars too feebly impressed to be recognizable.

Brachial valve contains concave cardinal plate pierced at apex by visceral foramen. Posterior end of cardinal plate bounded by dental sockets is triangular, anterior part of plate apparently extends beyond dental sockets. Crura arise from lateral components of cardinal plate. Median septum lacking (fig. 3), muscle scars too feebly impressed to be seen.

Jugum not observed in specimens studied. Large specimens have five to six volutions in the brachidium.

A figured specimen (pl. 2, figs. 30-33) measures 0.64 of a cm in width, 0.82 of a cm in length, and 0.64 of a $\mathrm{cm}$ in height.

Discussion.-Kozlowski (1929, p. 223) based his genus Protathyris primarily on the character of the jugum. Unfortunately, no specimens of $P$. sulcata or of the following species, $P$. nucleolata, have been found in which the jugum is preserved. However, the thin dental lamellae in the pedicle valve, the character of the hinge plate, and the absence of a median septum in the brachial valve all agree with Protathyris as described by Kozlowski.

Grabau (in Grabau and Sherzer, 1910, p. 148) assumed that Hindella had a median septum as described by Hall and Clarke (1894) and he proposed the genus Greenfieldia for shells resembling Whitfieldella exterternally but lacking a median septum in the brachial valve. The jugum of Greenfieldia whitfieldi, the type species, is not known, however, and the types have not been restudied. It is possible that if the jugum of Greenfieldia were found, it would be similar to that of Protathyris, and Greenfieldia would replace Protathyris because it has priority. Under these circumstances, it might be considered logical to put $P$. sulcata and $P$. nucleolata into Greenfieldia rather than Protathyris. However, Grabau (in Grabau and Sherzer, 1910, p. 151152, 156-157) described specimens which he considered $P$. sulcata and others which he compared with $P$. nucleolata, and he placed both species in Whitfieldella. Apparently, therefore, they did not agree with his concept of Greenfieldia.

Externally Protathyris sulcata bears a strong resemblance to Terebratula didyma Dalman, 1828, which Kozlowski (1929, p. 227-230) redescribed and assigned to Protathyris. Recently, however, Rubel and Modzalevskaya (1967) have restudied this species and made it the type of the new genus Didymothyris on the basis of a distinctive structure, the pedicle fulcrum, in the beak of the pedicle valve. Silicified specimens of Protathyris sulcata have been examined by me to see whether such a structure is present in the Cobleskill material, and because no indications of a pedicle fulcrum have been found, the species remains in Protathyris.

Size of sample.-More than 10 specimens were available for study.

Occurrence.-This very distinctive brachiopod was originally described by Vanuxem $(1842$, p. 112$)$ as occurring in the "Waterlime Group of Manlius," for which reason it was later discussed by Grabau (1900, p. 352) as a "typical Manlius limestone species $* * *$. It is not represented in the Coralline limestone." As Schuchert (1903b, p. 169) later pointed out, however, Vanuxem (1842, p. 111) included in his "Waterlime Group" everything between the base of the Cobleskill Limestone and the top of the Jamesville Member of the Manlius Limestone. Although Vanuxem did not mention the exact bed in which his "Atrypa sulcata" occurs, it is not associated with the fossils from the higher beds. Actually, Protathyris sulcata appears to be confined to the Cobleskill. It has been described from the Akron Dolomite by Grabau (1900, p. 367) and has 


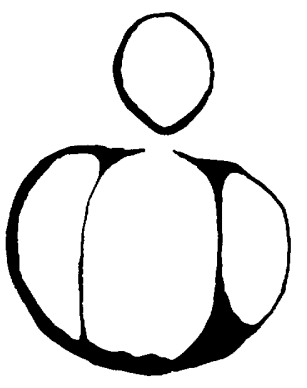

0.2

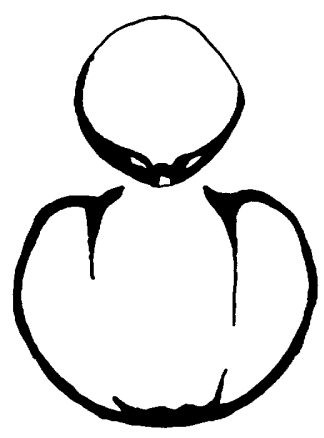

0.7

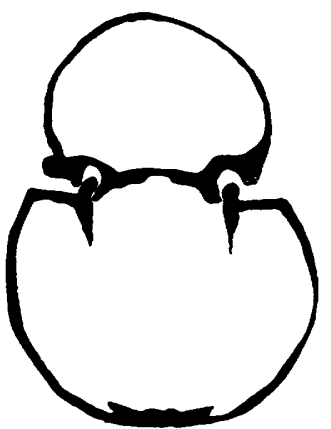

1.0

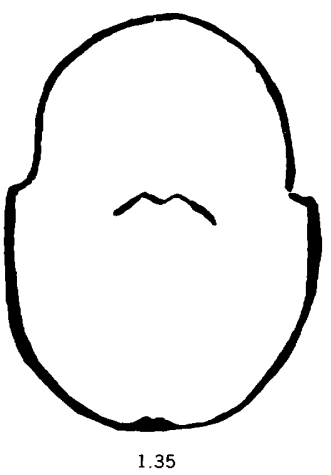

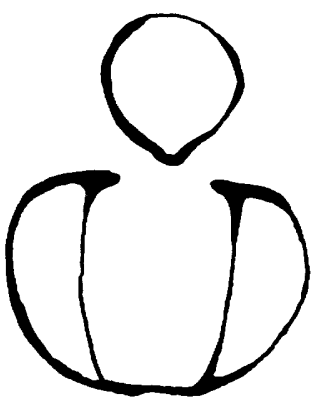
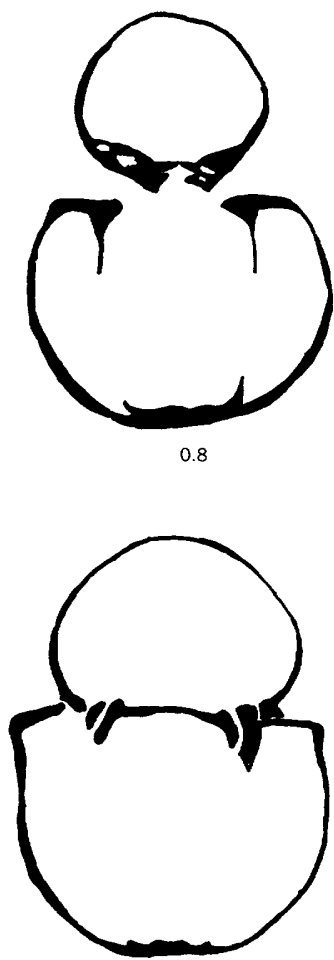

1.1

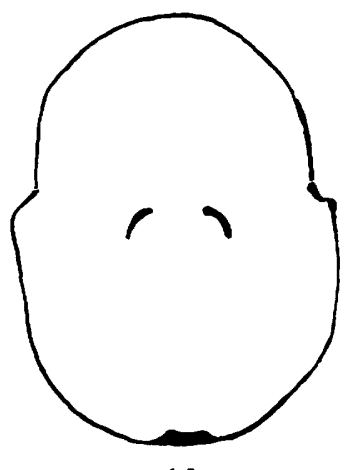

15

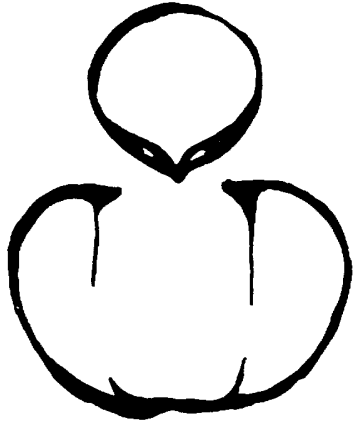

0.6

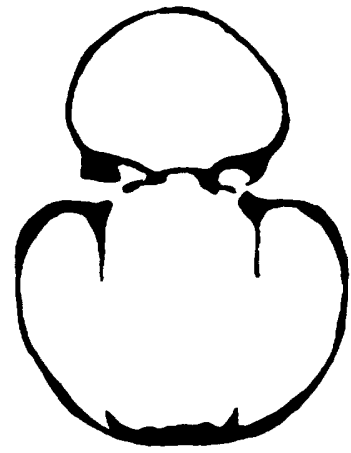

0.9

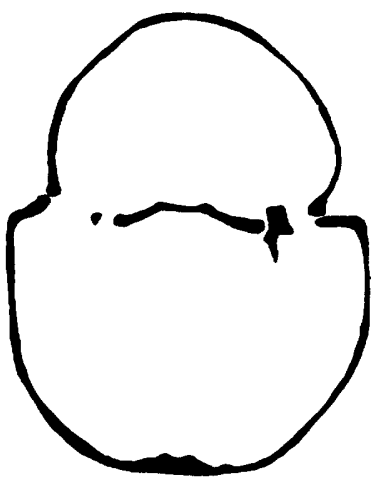

1.3

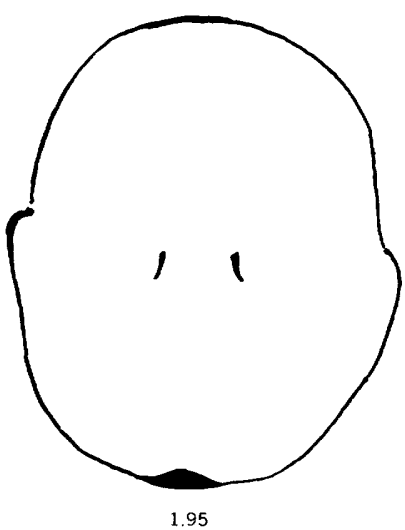

FIgure 3-Twelve transverse sections of Protathyris sulcata (Vanuxem) showing character of hinge plate and absence of median septum in brachial valve. Specimen from Aurelius Station (YPM colln. $\mathbf{5 2 4 4 / 1 . 5 6}$ ). Length before sectioning measured from beak of brachial valve, $9.3 \mathrm{~mm}$; measurements in millimeters from beak of brachial valve. 
been reported as far east as Litchfield, N.Y., by Schuchert (1903b, p. 167). The specimens in the collections studied come from Aurelius Station (YPM 5244/14; YPM 5244/1.56; USGS 3395-SD), Prospect Hill (USGS 5207-SD), and Forge Hollow (YPM 5244/90). In most collections it is associated with Howellella corallinensis eriensis and Morinorhynchus? interstriatus but is not very common anywhere.

\section{Protathyris nucleolata (Hall)}

Plate 2, figures $36-40$; figure 4

Atrypa nucleolata Hall, 1852, p. 328, pl. 74, figs. 10a-m.

Merista nucleolata (Hall). Hall, 1859, p. 78.

?Meristella nucleolata (Hall). Whitfield, 1882, p. 321, pl. 25, ifig. 5 .

Whitfieldella? nucleolata (Hall). Schuchert, 1897, p. 461; 1903b, p. 166.

Whitfieldella cf. rotundata (Whitfield). Grabau, 1900, p. 368, pl. 22 , figs. $3 a$, b.

Whitfieldella cf. nucleolata (Hall). Grabau in Grabau and Sherzer, 1910, p. 151-152, pl. 32, figs. 3a, b.

?Whitfieldella sulcata (Vanuxem). Williams, 1919, p. 89, pl. 27, figs. 4,5 .

Description.-Small, subcircular to subpentagonal in outline; width and length nearly equal, but former slightly greater. Anterior margin semicircular, but beak of pedicle valve extended so that posterolateral slopes are nearly straight, joining at an angle of about $100^{\circ}$. Valves nearly equally convex. Pedicle beak curves over and conceals delthyrium, brachial beak penetrates delthyrium. No distinct cardinal area. Pedicle valve with shallow, poorly defined sulcus in anterior part; brachial valve smooth or with low depression.

Surface smooth except for growth lines.

Pedicle valve with thin dental lamellae extending about one-fifth length of shell. No muscle scars observed.

Brachial valve with cardinal plate similar to that of $P$. sulcata except that visceral foramen appears larger and anterior part appears to extend farther forward (fig. 4).

Brachidium not observed in material at hand.

One figured specimen ( $\mathrm{pl} .2$, figs. $36-39$ ) is 0.9 of a $\mathrm{cm}$ in width, 0.8 of a cm in length, and 0.6 of a cm in thickness. Fragmentary specimens indicate that the species grew nearly twice as large but none are complete enough to measure.

Discussion.-This species is similar to Protathyris minuta (Maynard, in Schuchert and Maynard, 1913) from the Keyser Limestone, as redescribed by Bowen (1967, p. 36-37). However, $P$. minuta is smaller and more elongate; $P$. nucleolata has a subcircular outline even in juvenile specimens. Hindella? (Greenfieldia) congregata Swartz, 1923 from the Tonoloway Lime- stone resembles $P$. nucleolata in external appearance, but is reported to have a "low raised median line" (Prouty and Swartz, 1923, p. 460) or a myophragm (Bowen, 1967, p. 37) in the brachial valve.

Protathyris nucleolata apparently has a wider geographic distribution than $P$. sulcata, but is coextensive with it over the western and central part of New York. As far as relative abundance is concerned, the two species are more or less complementary, $P$. nucleolata being rare in the western part of the State and $P$. sulcata being rare in the east.

Size of sample.-More than 10 specimens were available for study.

Occurrence.-This species has been found in collections from Seneca Falls (USGS 6084-SD), Frontenac Island (USGS 3389-SD), Aurelius Station (YPM 5244/14), Jerusalem Hill (YPM 2594; YPM 5244/ 108), Schoharie (YPM 5244/146; USGS 3393-SD), and Shutter Corners (USGS 3390-SD). The species was originally described by Hall (1852, p. 328) from the Cobleskill Limestone at Schoharie. Subsequently it has been reported from equivalent horizons in Maryland (Schuchert and Maynard, 1913, p. 441, pl. 73, figs. 37-40), New Jersey (Weller, 1903, p. 241, pl. 21, figs. 38-40), and questionably from Pennsylvania (Reeside, 1917 , p. 202). Grabau (in Grabau and Sherzer, 1910, p. 151) recorded its presence in the Akron Dolomite of western New York.

Suborder SPIRIFERIDINA Waagen, 1883 Superfamily SPIRIFERACEA King, 1846 Family DELTHYRIDIDAE Waagen, 1883

Subfamily ACROSPIRIFERINAE Termier and Termier, 1949 Genus HoWELLELLA Kozlowski, 1946

Howellella corallinensis corallinensis (Grabau) Plate 2, figure 49

Spirifer crispus Hisinger. Hall, 1852, p. 328, pl, 74, figs. 9a-h. Spirifer crispus var. corallinensis Grabau, 1900, p. 352. Spirifer modestus var. corallinensis Schuchert, $1903 \mathrm{~b}$, p. 166. Spirifer corallinensis Grabau, 1903, p. 1042, fig. 6.

Howellella keyserensis (Swartz) [part]. Howell, 1947, pl. 3, fig. 4.

Description.-Shell small; outline subrhombic; cardinal angles rounded. Length between three-fourths and four-fifths of width in adult shells. Pedicle area small; pedicle beak curving quite far over it. Delthyrium large, open, with conspicuous deltidial plates that flare outward from delthyrium, except at apex, which is closed by an arcuate plate. Brachial beak and area low and inconspicuous.

Sulcus broad, shallow, and subangular in crosssection. Fold low, rounded, with slight depression on its crest in many specimens.

Ribs lacking, or indicated only by two faint linear depressions on each lateral slope of pedicle valve. 


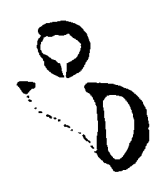

0.1

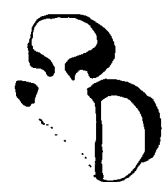

0.2

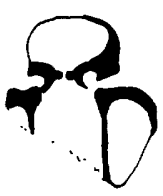

0.3

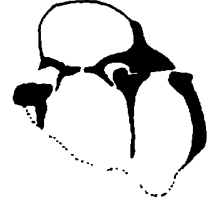

0.6

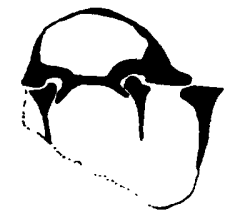

0.7

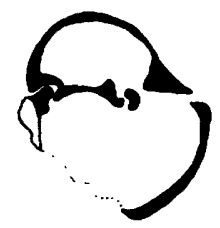

0.75

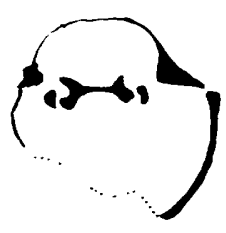

0.8

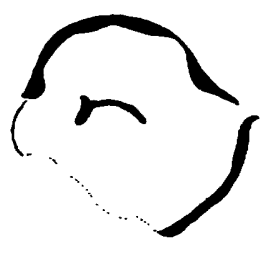

0.9

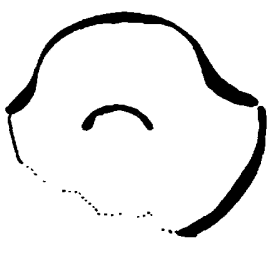

0.95

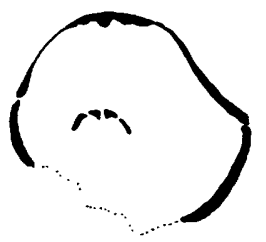

1.0

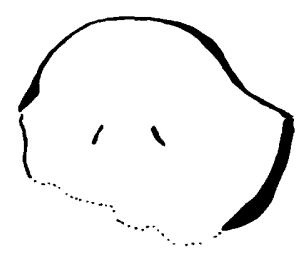

1.10

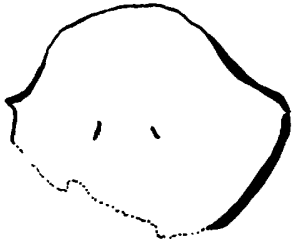

1.11

FIGURE 4.-Twelve transverse sections of Protathyris nucleolata (Hall) showing character of hinge plate and absence of median septum in brachial valve. Specimen from Schoharie, N.Y. (YPM colln. 5244/146). Length before sectioning, $6.6 \mathrm{~mm}$; measurements in millimeters from beak of pedicle valve.

Surface ornamentation consists of very small spinules on concentric growth varices; exfoliated shells appear completely smooth and varices not shown.

Pedicle valve contains dental lamellae extending about one-fourth of length of valve and, in most specimens, a low sharp median carina extending about half the length. Muscle scars not impressed and not recognizable as such.

Brachial valve contains small bilobed cardinal process. Crura supported by crural lamellae which extend about one-sixth the length and rest on floor of valve between dental sockets. Crural lamellae are perpendicular to floor for about half their height, where they are deflected laterally to connect with socket plates.

The holotype is $1.1 \mathrm{~cm}$ wide and 0.9 of a cm long. A large specimen is $1.3 \mathrm{~cm}$ wide and 0.9 of a cm long and an average specimen is $1.0 \mathrm{~cm}$ wide and 0.8 of a cm long.
Discussion.-The holotype of this species (AMNH 1771/4) is an exfoliated specimen that shows two distinct ribs on either side of the fold of the brachial valve, but the pedicle valve is smooth. Unlike some others of its genus, this small species shows no growth varices on exfoliated specimens.

Internally, $H$. corallinensis possesses the characters diagnostic of the genus Howellella. Although not observed in any of the specimens examined, the crura are probably attached to the crural lamellae at the junction of the vertical and diagonal components.

This species was described by Grabau (1900, p. 352) as a variety of "Spirifer" crispus (Hisinger). In a later paper, Grabau (1903, p. 1042) raised it to species rank and indicated that the type was the specimen figured as "S." crispus by Hall (1852, pl. 74, figs. 9d-f). Schuchert (1903b, p. 166) referred it to a variety of Howellella modesta (Hall, 1857) of the Maryland "Manlius" 
(now Keyser) Limestone, a similarity which Grabau had already noted. Most subsequent writers have considered $H$. corallinensis as a distinct species; but Swartz (1939, p. 385), Bowen (1967, p. 48), and Hoar and Bowen (1967, p. 26) have again suggested that both Howellella corallinensis and $H$. eriensis should be considered as varieties of the Maryland forms Howellella modesta and $H$. modesta plicata (Maynard, 1913). Though they stated that further study of the types of these varieties is necessary.

The problem of this group of nearly smooth species of Howellella involves not only the study of the types, but also examination of large suites of specimens. There is undoubtedly a very close relationship among all four forms, but comparison of the types shows that $H$. modesta not only shows less evidence of plication and a more feebly developed fold and sulcus than either of the New York species, but it also is less transverse. The holotype of $H$. modesta plicata is a far larger shell than either of the New York species and is distinctly plicate, as its name implies; but as the plications are not pronounced on the umbo, it would probably be difficult to distinguish a juvenile specimen of this species from mature $\boldsymbol{H}$. corallinensis. $\boldsymbol{H}$. corallinensis differs from $H$. eriensis only in the degree of plication and the depth and shape of the sulcus. These characters do not appear to be constant in large suites of specimens; consequently, $H$. eriensis is here considered a subspecies of $H$. corallinensis. The latter is here considered a distinct species because of the differences between it and the type of $H$. modest $a$ and because the specimens illustrated by Bowen (1967, pl. 6, figs. 21-28) suggest a relatively longer and thicker shell that has well-developed muscle scars. If these differences should prove to be due to paleoecological causes, it would be necessary to place $H$. corallinensis in synonymy with $H$. modesta.

The most obvious distinction among the four species of nearly smooth Howellella, two in New York and two in Maryland, is the degree of ribbing. If it is eventually demonstrated that $H$. corallinensis and $H$. modesta are the same, the name $H$. modesta has priority and must be used for all the nearly completely smooth species. However, if $H$. modesta plicata and $H$. eriensis also appear to represent the same form, $H$. eriensis has priority, and the Maryland forms should be referred to this subspecies.

Size of sample.-More than eight specimens wer available for study.

Ocurrence.-Howellella corallinensis corallinensis was described from the Cobleskill Limestone at Schoharie and has been found in collection YPM 5244/146. It also occurs in collections from Shutter Corners (YPM 5244/150), Central Bridge (YPM 5244/143),
Jerusalem Hill (YPM 2594), Aurelius Station (YPM $5244 / 14$ ), questionably from Frontenac Island (USGS 3389-SD), and from Seneca Falls (USGS 6084-SD).

\section{Howellella corallinensis eriensis (Grabau)}

Plate 2, figures $41-48$

Spirifer eriensis Grabau, 1900, p. 366, pl. 21, figs. 2a, b; Grabau, 1901, p. 199, fig. 119; Schuchert, 1903b, p. 166; Grabau, 1903, p. 1043, fig. 7 ; Grabau, 1906, p. 109, fig. 11 ; Grabau and Sherzer, 1910, p. 133, pl. 31, figs. 2a, b; Grabau and Shimer, 1909, p. 320, fig. 404; Maynard in Schuchert and Maynard, 1913, p. 404, pl. 69, fig. 7; Swartz, F. M., 1939, p. 385.

Howellella keyserensis (Swartz) [part]. Howell, 1947, p. 6-7, pl. 3, figs. 3, 5-7.

Description.-Shell subquadrate; cardinal angles rounded. Adult shells wider than long; length about three-quarters of width. Pedicle beak extended over relatively small cardinal area. Delthyrium large, open, bordered by flaring deltidial plates. Brachial beak low.

Sulcus moderately deep, broad, subangular in cross section, expanding rapidly toward anterior. Fold low and rounded. Three to four very subdued but distinct, rounded ribs on each lateral slope, separated by linear interspaces.

Surface ornamentation consists of small spinules in concentric bands. Growth varices may be conspicuous.

Interiors of both valves like typical $\boldsymbol{H}$. corallinensis.

The type specimen is $1.0 \mathrm{~cm}$ wide and 0.8 of a cm long; a larger specimen is $1.3 \mathrm{~cm}$ wide and $1.0 \mathrm{~cm}$ long.

Discussion.-The principal differences between $H$. corallinensis and the subspecies eriensis are the deeper, more angular sulcus and more distinct ribs of the latter. It was upon these characters that Grabau (1900, p. 366) based his species, though he noted at the time that a very close relationship must exist between the two forms. At the time that the new species was proposed, Grabau (1900, p. 351) believed that the Cobleskill Limestone at Schoharie and the Akron (Bullhead) Dolomite. at Williamsville were of different ages. When the two formations were later correlated, the two forms were left as distinct species because of the apparent differences between them.

A suite of specimens from Aurelius Station, N.Y., which is near the western limit of the Cobleskill and about halfway between Williamsville and Schoharie, contains forms which are gradational between the forms with a smooth shell and a shallow sulcus, representing H. corallinensis, and forms with ribbed shells and deep sulci, representing $\boldsymbol{H}$. eriensis. A smooth shell with a deep sulcus is relatively common. As the two forms are identical in all other respects, both in size and shape and internal characters, $\boldsymbol{H}$. eriensis is here considered 
a subspecies of $H$. corallinensis. Specimens with the characters of $H$. eriensis tend to have growth lamellae, unlike $H$. corallinensis, but this character seems to be subject to considerable individual variation and is probably not diagnostic.

Grabau (1903, p. 1044-1046) recognized the existence of intermediate forms between $H$. corallinensis and $H$. eriensis and suggested that the latter developed out of the former by an increasing tendency toward plication. He gave as evidence the fact that juvenile specimens of $H$. eriensis have the characters of $H$. corallinensis. This interpretation seems reasonable, and as $H$. corallinensis has page precedence, $H$. eriensis is here placed in a subspecific category.

Swartz (1939, p. 385) has suggested that "Spirifer" modestus var. plicatus Maynard should be put into synonymy with $H$. eriensis, the latter being perhaps a subspecies of $H$. modestus. Further study of the species from the Keyser Limestone may resolve this problem.

Size of sample.-More than 15 specimens, most of which are from Aurelius Station, were available for study.

Occurrence.-Howellella corallinesis eriensis was described from the Akron Dolomite of western New York and is most common in that area, although it has also been found in collections from the Cobleskill Limestone at Frontenac Island (USGS 3389-SD), Aurelius Station (YPM 5244/14; YPM 5244/1.56; USGS 3395SD), Prospect Hill (USGS 5207-SD), Forge Hollow (YPM 5244/90), and Jerusalem Hill (YPM 2594).

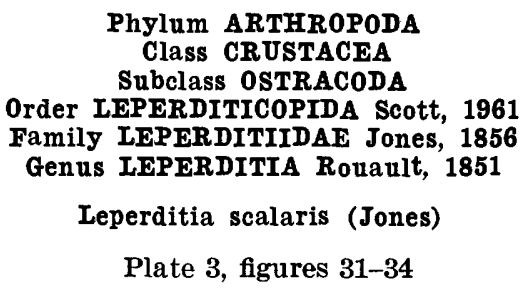

Plate 3, figures 31-34

Leperditia gibbera scalaris Jones, 1858a, p. 250, pl. 10, figs. 10, 11 ; Jones, $1858 \mathrm{~b}$, p. 834, fig. 698.

Leperditia scalaris Jones. Grabau, 1900, p. 371, pl. 22, figs. 6a-d ; 1901, p. 219, fig. 150 ; 1906, p. 111; Grabau and Shimer, 1910 , p. 340, fig. 1655; Grabau and Sherzer, 1910, p. 59, 202, 213, pl. 32, figs. 6a-d ; Williams, 1919, p. 86 ; Swartz, 1939, pl. 1, figs. 15a-c; Shimer and Shrock, 1944, pl. 280, figs. 5-8; Swartz, 1949, p. 312-313, pl. 65, figs. 3-10.

?Leperditia jonesi Hall, 1859, p. 372.

Description.-Lateral outline postplete; hinge line about two-thirds of the total length of the shell. Cardinal angles obtuse; posterior and ventral margins smoothly curved; anterodorsal margin straight. Longitudinal outline of shell a smooth curve, not inflated medially. Maximum thickness nearly median in dorsal view and dorsomedian in end view. Maximum length is along an axis at angle to hinge line, extending from the junction of the anterodorsal and ventral margins to the midpoint of the posterior margin. Maximum height in posterior third of shell.

Anterior and posterior margins have low, indistinct, flattened border. Ventral surface of the overlapping right valve is smoothly rounded in end view, ventral surface of overlapped left valve has smooth flange bordered by a narrow ridge marking the overlap of the right valve. Hinge taxodont. Rather prominent eye tubercles are in the anterior third of the carapace. The shell surface between the eye tubercle and anterodorsal cardinal angle tends to be uneven. Muscle scars in anterodorsal quarter of shell; adductor large, oval, with its long axis perpendicular to the hinge line, composed of 60-70 individual muscle flecks. Adductor is close to, but below and posterior to, chevron-shaped scar beneath eye tubercle. Chevron scar gently curved on anterior limb; posterior limb extends in a nearly straight line posterodorsally and merges with a line of small accessory scars which extend toward hinge line at a steep angle, where there are other small accessory scars. Pronounced swelling in posterodorsal third of left valve just below hinge line. Shell surface smooth or slightly punctate; in naturally or artifically corroded specimens it may appear slightly pustulose. In such specimens, canals radiating from the adductor scar may be seen on the external surface.

The dimensions of the largest figured specimen are $13.5 \mathrm{~mm}$ in length and $7.6 \mathrm{~mm}$ in height.

Discussion.-This species is characterized by the flattened anterior and posterior borders. Swartz (1949, p. 313 ) has suggested that the specimens of $L$. scalaris he illustrated from the Decker Limestone might possibly represent another species because the angulation of the anterior margin that he observed on his material was not illustrated by Jones. However, to judge from the Cobleskill and Akron specimens, this feature does not seem to be constant, and is not considered to be of specific value. Swartz (1949, pl. 65, figs. 9, 10) illustrated the muscle-scar pattern of $L$. scalaris on specimens from the Decker, and the Cobleskill specimens agree well with his illustrations except that the posterior limb of the chevron scar is more extended dorsally to merge with the small dorsal scars. In most of the Cobleskill material, the chevron scar is difficult to see in reflected light, although the adductor scar may be seen as a swelling on the surface of the shell. However, the chevron scar is more apt to be visible on internal molds.

Hall (1859, p. 372) described Leperditia jonesi from the Cobleskill of Schoharie County as a pustulose form, and separated it from L. alta (Conrad, 1842) from the Manlius Limestone (Lower Devonian) on the basis of its pustulose ornamentation. However, as corroded speci- 
mens of $L$. scalaris appear pustulose, it seems probable that Hall's material was merely badly weathered $L$. scalaris. The type of $L$. jonesi has not been examined, but the species is questionably placed in synonymy with $L$. scalaris.

Size of sample.-More than 10 valves were available for study, but no complete carapaces have been found.

Occurrence.-Leperditia scalaris has been found in collections from Frontenac Island (USGS 3389-SD), Aurelius Station (YPM 5244/14, USGS 3395-SD), Prospect Hill (USGS 5207-SD), Oriskany Falls (YPM 5244/88), Forge Hollow (YPM 5244/90), and Jerusalem Hill (YPM 2594). Although Hall (1859) described Leperditia jonesi from Schoharie, only one indeterminable leperditiid was found in the collections from that locality.

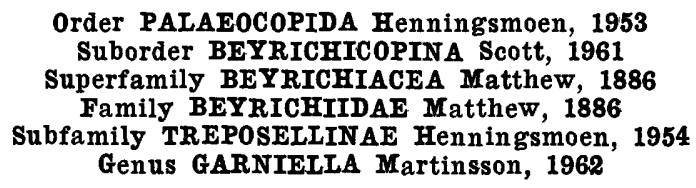

Garniella concentrica n. sp.

Plate 4, figures 9-12

Description.-Lateral outline amplete; dorsal margin straight. Free margin semicircular; greatest height from six-tenths to seven-tenths of length. Anterior cardinal angle obtuse; posterior cardinal angle nearly $90^{\circ}$. Valves essentially unisulcate, sulcus broad and deep, with vertical.walls and subrectangular ventral termination. Sulcus nearly median, subvertical; ventral end slightly curved anteriorly. Sulcus extends about twothirds the height of the valve. Velum flat to slightly concave upward in lateral view, apparently tubulous, extending entirely around free margin.

Valve surfaces coarsely reticulate except for velum and median sulcus. Reticulation arranged roughly concentrically around the sulcus and parallel to the free margin. Although the preadductorial lobe is not developed as a distinct structure, its position is indicated by the pattern of the reticulation. Below the adductorial sulcus, and bounding it ventrally, the reticulations are accentuated to form a slight crista, which is paralleled by another separated by one row of reticulations, which are depressed into a distinct groove.

Heteromorph has anteroventral crumina ornamented by four cristae, which extend from the posterior to the anterior end of the crumina parallel to the free margin.

The dimensions of the figured specimen are $1.10 \mathrm{~mm}$ in length and 0.70 of a $\mathrm{mm}$ in height. Another tecnomorph is $1.25 \mathrm{~mm}$ long and 0.70 of a mm high.

Types.-Holotype, USNM 162309 ; paratypes, USNM 162308, YPM 23820, YPM 23821.
Discussion.-Although the only heteromorphic specimen is badly crushed (pl.4, fig. 11), the cristate crumina definitely places this species in Garniella Martinsson, 1962. It differs from all described species of Garniella, except $G$. biseriata Martinsson, 1962, in having the cristae extending to the anterior end of the crumina. From $G$. biseriata it differs in having a larger number of cristae and a much larger fused anterior and median lobe. This species is not common in the Cobleskill, but is quite distinctive. This is the first occurrence of the genus in the Eastern United States.

Size of sample.-Seven specimens were available for study, of which one was a crushed heteromorphic carapace.

Occurrence.-Garniella concentrica has been found in collections from Schoharie (YPM 5244/146, USGS 3393-SD, USGS 7283-SD, USGS 8063-SD) and Jerusalem Hill (YPM 2594).

\section{Subfamily AMPHITOX0TIDINAE Martinsson, 1962 Genus MIGMATELLA n. gen.}

Type species.-Migmatella martinssoni $\mathrm{n}$. sp. Species included.-Only the type species.

Diagnosis.-Trilobate amphitoxotidine beyrichiids with velum reduced in heteromorphs to velar bend except on left valve, where a velar remnant protrudes as a spur posterior to the crumina. Trace of velum on ventral surface of crumina makes scar which is convex toward the plane of commissure of valves. No torus in either tecnomorphs or heteromorphs. Tecnomorphs have obscurely tubulous velum restricted posteriorly on left valve, more restricted on right valve. Lobes emaciated, cuspate, and cristate in tecnomorphs, not cristate in heteromorphs.

Discussion.-This genus is closely related to Martinsson's three genera Juviella, Lophoctenella, and Cryptolopholobus-especially the latter, which it resembles in having cristate lobes in the tecnomorph but not in the heteromorph. However, it differs from all three genera in having a more restricted velum and in lacking a torus. The preservation of the specimens studied is not good enough to determine whether a denticulate crest is present on the velum as in Lophoctenella and Cryptolopholobus. The name Migmatella is derived from the Greek word "migma," mixture, because the genus partakes of some but not all of the characters of Martinsson's three genera.

Stratigraphic range.-At present, Migmatella is known only from beds of Late Silurian age in eastern North America. The genus is present in the Decker Limestone in Pennsylvania, but as yet not enough wellpreserved specimens have been obtained to determine whether they represent $M$. martinssoni or a new species. 
Migmatella martinssoni n. sp.

Plate 4, figures 13-22

Description.-Lateral outline preplete; lobes narrow and sulci wide, giving carapace an emaciated appearance. Adductorial sulcus broad and deep, extending twothirds of distance from dorsal margin to velum. Prenodal sulcus broad and deep, extending about one-third of distance from dorsal margin to velum. There is a large and pronounced anteroventral depression beneath the preadductorial lobe of the tecnomorphs. All lobes are cuspate and protrude over the hinge line. In tecnomorphs, the preadductorial lobe is narrow, nearly isolated, and subovate; the anterior lobe is thin, as is the syllobium. All lobes in the tecnomorphs are bordered by cristae, which do not occur on the heteromorphs. The general pattern of lobation looks like a slightly distorted $\mathrm{W}$. The velum on the tecnomorphs is wider on the left valve than on the right valve, but is relatively narrow on both, and although tubulous, the tubules are not readily seen. On heteromorphs, the velum is reduced to a velar bend except for a blunt spur beneath the syllobium of the left valve and a velar trace across the ventral surface of the crumina. The crumina is subglobular in outline.

The ornamentation on the specimens studied is not will preserved, but the tecnomorphs are apparently reticulate between the cristae on the lobes; the heteromorphs are apparently slightly reticulate.

The dimensions of the holotype heteromorph are 1.30 $\mathrm{mm}$ in length and 0.65 of a $\mathrm{mm}$ in height. A tecnomorph is $1.10 \mathrm{~mm}$ in length and 0.80 of a $\mathrm{mm}$ in height.

Types.-Holotype, USNM 162314 ; paratypes, USNM 162310-162313, YPM 23822-YPM 23824.

Discussion.-Although there are marked differences between the tecnomorphs and heteromorphs, such as the cristate lobes of the former, it is improbable that more than one species is present as no other amphitoxotidines in any of the collections resemble either the tecnomorphs or heteromorphs of $M$. martinssoni. The species is named in honor of Anders Martinsson, who has clarified the systematics of the Beyrichiidae.

Size of sample.-This species is based upon 23 specimens, of which three are tecnomorphic carapaces and one is a heteromorphic carapace.

Occurrence.-Seventeen of the 23 specimens came from collections from Schoharie, N.Y. (USGS 3393SD, USGS 7283-SD, USGS 8063-SD and YPM 5244/ 146). One small tecnomorph came from Shutter Corners, N.Y. (USGS 3390-SD). One heteromorph and one tecnomorph have been found in a collection from Howes Cave, N.Y. (USGS 8065-SD), and one heteromorph has been found near Central Bridge, N.Y. (USGS
7198-SD). Two additional specimens came from a collection made by C. E. Beecher from Jerusalem Hill, N.Y. (YPM 2594).

\section{Genus DIBOLBINA Ulrich and Bassler, 1923 \\ Dibolbina reticruminata $\mathbf{n}$. sp. \\ Plate 4, figures 23-28}

Description.-Lateral outline amplete; height from dorsum to velum only about one-third of length. Syllobium broad, inflated and subtriangular in lateral view. Adductorial sulcus deep, narrow, slanted anteriorly. Preadductorial lobe is a small round knob, poorly defined by anterior sulcus, which is very shallow and indistinct. Velum very wide, flaring away from contact margin at a high angle; it is nearly at right angles to the plane of commissure. Velum distinctly tubulous. Crumina large, ovate; velum continues across it as a distinct tubulous crest. Distinct torus below velum does not cross crumina. Surface smooth, except for crumina of heteromorph, which is finely punctate, the punctae being arranged in parallel lines so that they appear as fine striae.

The dimensions of a tecnomorph (incomplete) are $1.15 \mathrm{~mm}$ in length and 0.37 of a $\mathrm{mm}$ in height. The holotype heteromorph is $1.55 \mathrm{~mm}$ in length and 0.5 of a $\mathrm{mm}$ in height to velum. The width across the crumina of the holotype is $1.3 \mathrm{~mm}$.

Types.-Holotype, YPM 23826; paratypes, YPM 23825, USNM 162315-162317.

Discussion.-The lobation of this species is so similar to that of Dibolbina cristata Ulrich and Bassler, 1923, and D. producta Ulrich and Bassler, 1923, that there is little doubt about the generic assignment. From $D$. cristata it differs in lacking the fine crista on the syllobium, and from $D$. producta in having a deeper adductorial sulcus and a more pronounced preadductorial lobe. It lacks, as does $D$. producta, the basal crest outlining the velum which is present in $D$. cristata. The ventral morphology of the cruminae of D. producta and D. cristata is not as yet known. The syntypes of $D$. cristata, the type species of Dibolbina, include one heteromorphic valve, figured by Kesling (in Kesling and Wagner 1956, pl. 4, fig. 13), but the crumina is crushed, and it is not possible to prepare it to show the ventral side. Until topotype material of $D$. cristata is available for study, it is assumed that the crumina of $D$. reticruminata is representative of the genus. In this connection, note that, unlike the related genus Berolinella Martinsson, 1962, the torus in Dibolbina does not cross the crumina.

Size of sample.-Eight specimens, of which three were complete heteromorphic carapaces, and several fragments were available for study. Because of the long 
hinge line and deep median sulcus, this species is diffcult to recover unbroken.

Occurrence.-With the exception of one tecnomorph from the collection at Shutter Corners (USGS 3390SD), all specimens were found in collections from Schoharie (YPM 5244/146, USGS 7283-SD, USGS 8062-SD).

\section{Genus HAMMARIELLA Martinsson, 1962}

Hammariella warthini n. sp.

Plate 4, figures 1-8

Description.-Lateral outline preplete; anterior lobe broad, with low cusp; preadductorial lobe ovate to subpyriform, not extending to dorsal margin; syllobium broad, low, without cusps. Prenodal sulcus broad but fairly shallow; adductorial sulcus deep and wide. There is an anteroventral depression beneath the preadductorial lobe of tecnomorphs. Striated velum in tecnomorphs extends in a smooth curve from about midheight on anterior end to about midheight on posterior end. Heteromorph has ovate crumina that is not crossed by either velum or torus. Velum of heteromorph extends from about midheight to crumina posteriorly and is represented only by a velar bend anteriorly. Surface of valves very finely punctate; crumina finely striate over entire surface. Velum in some specimens with fine concentric striations.

The dimensions of a tecnomorph are $1.25 \mathrm{~mm}$ in length and 0.85 of a $\mathrm{mm}$ in height including the velum. A heteromorph is $1.35 \mathrm{~mm}$ in length and $1.0 \mathrm{~mm}$ in height including the crumina.

Types.-Holotype, USNM 162304; paratypes USNM 162302, USNM 162303, USNM 162305-162307, YPM 23819.

Discussion.-This species differs from the type of the genus, Hammariella pulchrivelata Martinsson, 1962, in having a narrower velum that extends closer to the hinge line. Furthermore, Hammariella pulchrivelata has the velum abruptly truncated posteriorly, whereas in $H$. warthini the velum curves smoothly into the surface of the valve. However, the lack of either torus or velum crossing the crumina and the restricted velum, lacking anterior to the crumina, suggest that this species belongs in Hammariella.

According to Martinsson (1967, p. 360, 369-370), $H$. pulchrivelata is characteristic of a zone in the lower part of the Ludlow in the Baltic region. It is interesting that $H$. warthini, the first species of Hammariella to be reported from North America, occurs in beds which are considerably younger.

Size of sample.-Four tecnomorphic left valves and four heteromorphic valves, two right and two left, were available for study. None are unbroken, but the morphology of the species can be determined from examining all of them.

Occurrence.-Hammariella warthini has been found only in collections from Schoharie (USGS 7283-SD, USGS 8062-SD).

\section{Subfamily BEYRICHIINAE Matthew, 1886} Genus KLOEDENIOPSIS n. gen.

\section{Type species.-Kloedeniopsis hartnageli n. sp.}

Species included.-

Beyrichia barretti Weller, 1903.

Kloedenia centricomis Ulrich and Bassler, 1908.

Kloedenia crassipunctata Swartz and Whitmore, 1956. Kloedenia duplicipunctata Swartz and Whitmore, 1956. Kloedenia fimbriata Ulrich and Bassler, 1908.

*Kloedeniopsis hartnageli $\mathrm{n}$. sp.

Kloedenia kokomoensis Foerste, 1909.

Kloedenia retifera Ulrich and Bassler, 1908.

Diagnosis.-Distinctly trilobate beyrichiines with lobes set below dorsal margin and merging smoothly into it. Lobes neither cuspate nor faceted, no fissus. Marginal structure clearly distinct from domicilium but forming contact margin of valves, so that in end view the carapace appears keeled. Lateral outline amplete in tecnomorphs of most species. Crumina entirely on domicilium, ovate, anteroventral, clearly defined. Crumina does not interrupt marginal structure but may hang below it in lateral view. Ventral surface of crumina smooth or finely striate. Surface of valves smooth or reticulate.

Discussion.-The genus Kloedeniopsis is here proposed to include a group of North American beyrichiacean species in which the velar and marginal ridges appear to be fused into a flattened marginal rim. A narrow marginal surface is developed on the left valve, which completely overlaps the right valve; there is no canaliculus (Henningsmoen, 1965, p. 341). Kloedeniopsis differs from the similar genera Lophokloedenia Swartz and Whitmore, 1956 and Zygobeyrichia Ulrich, 1916 in the character of the margin, as both of these genera have a velar ridge which is separated from the contact margin and marginal ridge so that there is a distinct marginal surface on each valve and a canaliculus is developed. In addition, in both of these genera the crumina of the heteromorph interrupts and displaces the velar ridge, whereas in Kloedeniopsis the crumina does not affect the marginal structure. The genus Arikloedenia Adamczak (1968, p. 72) resembles Kloedeniopsis in lobation, but lacks the distinct marginal structure. Forms illustrated as Welleriella Abushik (1968, pl. 37, figs. 9, 10, 18, 19) from the Lower Devonian Ivane horizon of Podolia appear to be related to Kloedeniopsis, 
but are not as distinctly lobate and do not have as distinct a marginal structure.

Martinsson (1962, p. 347) has suggested that most of the North American beyrichiid species assigned to Kloedenia Jones and Holl, 1886 do not belong in that genus. As redefined by Martinsson (1963, p. 41), Kloedenia s.s. is characterized by reduced lobation except for a prominent cristate preadductorial lobe which protrudes over the hinge line in lateral view and a crumina which is ornamented ventrally by three striate ridges and is assimilated with the domicilium. In contrast, the North American species assigned to Kloedenia have a rounded or globular noncristate preadductorial lobe which never protrudes above the hinge line in lateral view and a crumina which is distinctly set off from the domicilium. The concept of Kloedenia followed by North American authors is generally that of Ulrich and Bassler (1908, p. 300-303), who listed 21 American species originally, and subsequently (Ulrich and Bassler, 1923, p. 639-641) described six more. Later authors have added additional species and removed some from the genus, but at present there are between 25 and 30 species assigned to Kloedenia which are not congeneric with the type species, Kloedenia wilckensiana Jones, 1855.

Several of these species are here included in Kloedeniopsis, and others may belong to Lophokloedenia Swartz and Whitmore, 1956 or Welleriopsis Swartz and Whitmore, 1956. For example, specimens of "Kloedenia" granulata Hall, 1859, from the Coeymans Limestone of New York show a dorsal crest and node over the adductorial sulcus suggestive of Lophokloedenia, and the holotype of "Kloedenia" oculina Hall, 1859 (NYSM 4144) appears to be a tecnomorphic specimen of Welleriopsis. However, several species assigned to Kloedenia do not agree well with any of the described genera. If, as is here assumed, the marginal structures have taxonomic significance, at least two groups may be recognized among these unresolved species. One such group is represented by "Kloedenia" normalis Ulrich and Bassler, 1923 and related species. In these species the velar structure is subdued and is more of a bend than a distinct ridge or flange; it is well separated from the marginal structure by a marginal surface. The crumina of "Kloedenia" normalis is large, anteroventral, distinctly set off from the domicilium and apparently does not displace the velar bend. The ventral surface of the crumina is finely striate. The lectotype (USNM 162287 ) is here designated for "Kloedenia" normalis as a heteromorphic left valve selected from the original six syntypes bearing the number USNM 82997. It is illustrated on plate 3 , figure 1 , for comparison with Kloedeniopsis hartnageli.
The second group of unresolved species is represented by "Kloedenia" montaguensis (Weller, 1903). This group resembles the genera Lophokloedenia and Zygobeyrichia in having a velar ridge which is separated from the marginal ridge so that a canaliculus is developed, and in having the crumina displacing the velar ridge. However, these unresolved species lack the cristate syllobium and node in the dorsal end of the adductorial sulcus characteristic of Lophokloedenia, and also lack the ventral extension of the prenodal sulcus characteristics of Zygobeyrichia. The relationship of "Kloedenia" montaguensis and allied forms to Lophokloedenia and Zygobeyrichia needs further detailed study.

A diagram of the inferred cross sections of "Kloedenia" normalis, Kloedeniopsis hartnageli, and "Kloedenia" montaguensis showing the velar and marginal structures discussed above is given in figure 5. A complete carapace was available only for Kloedeniopsis hartnageli; however, the contact margins of both valves of the other two species were visible and the reconstructions are believed to be correct.

The relationship of the velar to the marginal structures may prove to have some stratigraphic significance, as present knowledge indicates that species having the kind of margin shown by "Kloedenia" normalis occur lower in the section than those having the kind of margin of either "Kloedenia" montaguensis or Kloedeniopsis.

Martinsson (1963, p. 19) listed six genera, Bingeria Martinsson, 1962; Lophokloedenia Swartz and Whitmore, 1956; Welleriopsis Swartz and Whitmore, 1956; Pseudobeyrichia Swartz and Whitmore, 1956; Welleria Ulrich and Bassler, 1923; and Zygobeyrichia Ulrich, 1916; which resemble the Kloedeniinae in having a long, ovate crumina more or less assimilated with the

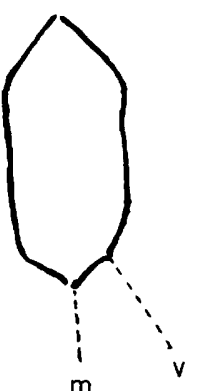

$A$

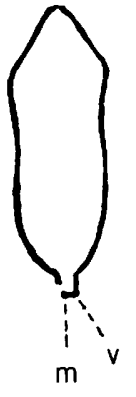

$B$

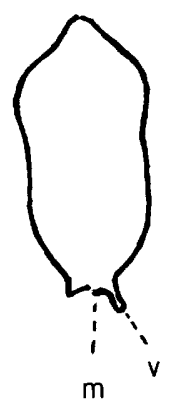

C
Figure 5.--Inferred cross sections through the preadductorial lobe showing the relationship of the velar ridge to the marginal ridge in three groups of North American beyrichiaceans. A, "Kloedenia" normalis Ulrich and Bassler, 1923; $B$, Kloedeniopsis hartnageli n. sp; $C$, "Kloedenia" montaguensis (Weller, 1903) ; $\mathrm{m}$, marginal ridge; $\mathrm{v}$, velar ridge. 
domicilium, but that cannot be placed in that subfamily as currently defined and appear to be more closely related to the Beyrichiinae. With the exception of Bingeria, all these genera are North American. Kesling $(1969$, p. 291$)$ has noted that Welleriopsis, Lophokloedenia, Zygobeyrichia, and Bingeria have a flangelike velum and with further study these might be separated as a new subfamily. Other genera that need investigation are Cornikloedenia Henningsmoen, 1954 and Pintopsis Copeland, 1964. The new genus Kloedeniopsis appears to be more closely allied to the group of genera discussed above than to the true beyrichiines, but is here placed in the Beyrichiinae pending a revision of the group as a whole.

The name Kloedeniopsis has been given to this genus because of its superficial resemblance to Kloedenia Jones and Holl, 1886.

The range of this genus as currently understood is from the Murderian Stage of Fisher (1960), or late Pridoli, through the Helderbergian Stage, or Gedinnian and early Siegenian; that is, from latest Silurian through earliest Devonian.

\section{Kloedeniopsis hartnageli $n$. sp.}

Plate 3, figures 2-10

Kloedenia notata (Hall). Jones, 1890, pl. 4, figs. 22, 23.

Description.-Lateral outline amplete, nearly twice as long as high. Lobation subdued; adductorial sulcus relatively shallow and narrow, extending from slightly more than half to slightly less than half the distance between the hinge line and the velar ridge. Prenodal sulcus shallow, short, and straight. Preadductorial lobe subdued, not rising far above level of valve surface in dorsal view, subrectangular to ovate in lateral outline. Syllobium broad, evenly curved, and nearly twice the width of the anterior lobe. Dorsal border surface very narrow. Velar ridge narrow, wider on left valve than on right valve; perilobal depression poorly developed. Shell surface smooth on well-preserved specimens.

Heteromorphs tend to have more ovate preadductorial lobe. Crumina is large, ovate anteroventral swelling of domicilium which isolates preadductorial lobe and overhangs velar ridge, extending posteriorly of adductorial sulcus. Ventral surface of crumina is smooth or with extremely fine longitudinal striae.

The dimensions of a large tecnomorphic valve are $2.75 \mathrm{~mm}$ in length and $1.50 \mathrm{~mm}$ in height; of a heteromorphic valve, $2.50 \mathrm{~mm}$ in length and $1.40 \mathrm{~mm}$ in height.

Types.-Holotypes, USNM 162285; paratypes, USNM 162286, USNM 162286a, USNM 162286b, USNM 162286c, YPM 23813, YPM 23814.
Discussion.-This species is characterized by its smooth surface and rather elongate subrectangular outline. With the exception of Kloedeniopsis kokomoensis (Foerste, 1909), all other species here assigned to Kloedeniopsis are reticulate or punctate. The holotype (USNM 87133) of K. kolkomoensis is a coarsely silicified tecnomorphic carapace about $3 \mathrm{~mm}$ long, which may have been smooth, although the preservation is so poor that it is impossible to be certain. It differs from $K$. hartnageli in having a broader, more prominent preadductorial lobe and an inflated syllobium.

The specimens illustrated by Jones (1890, pl. 4, figs. $22,23)$ as Kloedenia notata (Hall, 1859) are here assigned to Kloedeniopsis hartnageli. Through the courtesy of Dr. R. H. Bate I have been able to borrow from the British Museum (Natural History) the slab (BMNH In 35128) on which is the holotype of Dizygopleura hallii (Jones, 1890), which according to Jones $(1890$, p. 14, 15) is associated with Kloedenia notata. This slab is considered to be from the Cobleskill Limestone for reasons given under the discussion of Dizygopleura hallii later in this paper. The slab has on one surface many specimens of Kloedeniopsis hartnageli, two of which are believed to be the specimens figured by Jones as Kloedenia notata. Jones $(1890$, p. 14, 15) indicated that his specimens came from the Waterlime Group, which in 1890 would have included the Cobleskill Limestone, but Hall (1859, p. 380) had described his "Beyrichia" notata as coming from the "tentaculite limestone, and base of the shaly limestone of the Lower Helderberg group, Herkimer county," which in current terminology would imply that it came from the Manlius Limestone and the Kalkberg Limestone, respectively (Berdan, 1964, p. B4). Hall did not figure his specimens but described "Beyrichia" notata (Hall, 1859, p. 379) as having a finely granulose surface. It seems unlikely that Jones' smooth specimens from the Cobleskill are conspecific with Hall's finely granulose types from the Manlius or Kalkberg. The present location of Hall's types of "Beyrichia" notata is not known, but his description of the species could apply to any of several species of beyrichiid ostracodes in the Manlius Limestone.

Size of sample.-Kloedeniopsis hartnageli is one of the more common species in the Cobleskill Limestone. More than 25 specimens were available for study.

Occurrence.-This species has been found in collections from Frontenac Island (USGS 3389-SD), Aurelius Station (YPM 5200/14, USGS 3395-SD), Prospect Hill (USGS 5207-SD), Oriskany Falls (YPM 5244/ 88), Forge Hollow (YPM 5244/90), Jerusalem Hill (YPM 2594), Howes Cave (USGS 8065-SD), Scho- 
harie (YPM 5244/146, USGS 3393-SD, and others), and Shutter Corners (YPM 5244/150, USGS 3390SD).

\section{Kloedeniopsis barretti (Weller) \\ Plate 3, figures 12-17}

Beyrichia barretti Weller, 1903, p. 254, pl. 23, fig. 9.

Kloedenia barretti (Weller). Ulrich and Bassler, 1908, p. 301; 1913, p. 532, pl. 97, fig. 17 ; Bassler, 1915, p. 684.

Zygobeyrichia barretti (Weller). Swartz and Whitmore, 1956, p. 1072-1073, pl. 108, figs. 14-17.

Zygobeyrichia ? barretti (Weller). Berdan, 1964, p. B15.

Description.-Lateral outline amplete, subquadrate. Adductorial sulcus wide and deep, slightly inclined anteriorly, extending between one-half and two-thirds the distance from the hingeline to the velar ridge. Prenodal sulcus narrow, nearly as long as the adductorial sulcus, tends to swing posteriorly isolating the preadductorial lobe. Preadductorial lobe suboval in outline, does not protrude laterally far above valve surface. Velar ridge wide on left valve and fringed with short, widely spaced spinelets, narrow ventrally on right valve. Distinct perilobal groove separates velar ridge from domicilium. Surface of valves ornamented with coarse irregular reticulation except on velar ridge and sulci. Dorsal surface narrow.

Crumina is anteroventral expansion of domicilium which may or may not overhang velar ridge. Crumina coarsely reticulate except on ventral surface, which is finely striate.

Two tecnomorphs are $2.65 \mathrm{~mm}$ in length and $1.64 \mathrm{~mm}$ in height, and $2.50 \mathrm{~mm}$ in length and $1.77 \mathrm{~mm}$ in height, respectively. A heteromorph is $2.71 \mathrm{~mm}$ in length and $1.70 \mathrm{~mm}$ in height.

Discussion.-Swartz and Whitmore (1956, p. 10721073) placed this species in Zygobeyrichia and stated that the zygobeyrichiid ventromedian swelling and post-median [sic] subventral furrow are well marked. Their illustrations (Swartz and Whitmore, 1956, pl. 108, figs. 14-17) of the holotype also show these features. However, although the very irregular flat-bottomed reticulation characteristic of $Z$. barretti is present on the specimens from the Cobleskill, most of them do not show the anteroventral furrow of Zygobeyrichia. The similarity in ornamentation and lobation suggests strongly that the Cobleskill specimens are conspecific with $Z$. barretti, but the absence of a well-developed zygobeyrichiid furrow raises doubts about the generic assignment of the species. Furthermore, the marginal structures of $Z$. barretti are those of Kloedeniopsis, not $Z$ ygobeyrichia as represented by $Z$. apicalis Ulrich, 1916, the type species of the genus. Consequently, the species is here referred to Kloedeniopsis, although the sulci of $K$. barretti are longer and deeper than those of any other species assigned to the genus.

Size of sample.-This species is abundant in the eastern part of the Cobleskill outcrop belt. More than 30 specimens were available for study, including more than 10 complete carapaces.

Occurrence.-This species has been found in the Cobleskill Limestone in collections from Schoharie (USGS 3393-SD, USGS 8063-SD, YPM 5244/146) and Howes Cave (USGS 8065-SD) and in collections from the Decker Limestone of New Jersey and the Keyser Limestone of Maryland.

\section{Genus TIKIOPSIS n. gen.}

Type species.-Tikiopsis denticulata $\mathrm{n}$. sp.

Species included.-Only the type species.

Diagnosis.-Trilobate beyrichiines with deep sulci that tend to isolate preadductorial lobe. Anterior lobe and syllobium bluntly cuspate and may rise above dorsal margin in lateral view; preadductorial lobe set well below dorsal margin. Dorsal and ventral surfaces broad, so that complete carapace is wide and boxlike. Velar ridge narrow but distinct, with adnate flap or thickening on ventral surfaces of both valves. Heteromorph not known.

Discussion.-Although few specimens are available and only the tecnomorph is as yet known, the type species is so distinctive that it cannot be placed in any described genus. The peculiar ventral "flap" or thickening of the ventral surface appears to be unique, as do also the deep sulci isolating the preadductorial lobe. Tikiopsis appears to be most closely related to Welleriopsis Swartz and Whitmore, 1956, but the latter has short sulci which do not extend more than half the height of the valve, and the prenodal sulcus is shallow. Specimens of Welleriopsis sp. cf. W. jerseyensis (Weller, 1903) from the Wilbur Limestone of the Hudson Valley and $W$. sp. cf. W. diplocystulis Swartz and Whitmore, 1956 from the Coeymans Limestone of central New York do not show the ventral adnate flap of Titiopsis.

The generic name is derived from the resemblance of the dorsal aspect of a complete carapace to the Polynesian carved wooden figures called "tikis."

\section{Tikiopsis denticulata n. sp. \\ Plate 3, figures 24-30}

Description.-Lateral outline amplete, subquadrate to subcircular; cardinal angles obtuse; hinge line less than greatest length of shell. Height approximately four-fifths of length. Adductorial sulcus deep, narrow, extending two-thirds of distance from dorsal margin 
to velar ridge; prenodal sulcus deep, narrow, curves around to unite with adductorial sulcus dorsally and ventrally, tending to isolate preadductorial lobe. Preadductorial lobe suboval in outline, set well below dorsal margin; anterior lobe and syllobium bluntly cuspate, forming a broad dorsal border surface into which hinge line is slightly incised. Velar ridge narrow ventrally, wider at cardinal angles, separated from domicilium by narrow furrow. Domicilum inflated; free marginal surfaces broad, so that carapace appears boxlike. Ventral surface of velar ridge has adnate flaplike thickening. Contact margin marked by a row of small interlocking denticles on both valves.

Shell surface smooth. Heteromorph not known.

The holotype is $2.50 \mathrm{~mm}$ in length and $1.75 \mathrm{~mm}$ in height, and another complete carapace is $2.50 \mathrm{~mm}$ in length and $1.80 \mathrm{~mm}$ in height. A larger single left valve is $2.75 \mathrm{~mm}$ in length and $1.85 \mathrm{~mm}$ in height. The smallest specimen found is $2.0 \mathrm{~mm}$ in length and $1.25 \mathrm{~mm}$ in height.

Types.-Holotype, USNM 162292 ; paratypes USNM 162292a, USNM 162293, USNM 162293a, YPM 2381623818.

Discussion.-As yet no specimens have been found which can be considered to be heteromorphs of this species. Although the adnate flap of the velar ridge on the ventral surface suggests cruminal structures of heteromorphs of other beyrichiacean ostracodes, no indications of a crumina have been found in any of the specimens studied, and all the specimens are probably tecnomorphs. Further evidence for this view is that the position of maximum width is posterior for all specimens. The smallest specimen (USNM 162292a), which presumably represents a preadult instar, shows the adnate flap developing as a fold on the velar ridge (pl. 3, fig. 30). The significance of this structure is not clear, but it apparently is not analogous to the velar flap on the crumina of other beyrichiaceans. When heteromorphic individuals of Tikiopsis denticulata are found, its relationships may be clarified. The specific name is based on the presence of interlocking denticles along the contact margin.

Size of sample.-Fifteen reasonably complete specimens were available for study, of which two are complete carapaces and one is a broken carapace. In addition, many fragmentary specimens were examined.

Occurrence.-In collections from "crinoidal" limestone at Shutter Corners (YPM 5244/150, USGS 3390SD), Central Bridge (USGS 7198-SD) and Schoharie (YPM 5244/146, USGS 3393-SD, USGS 8063-SD, USGS 8439-SD).

\section{Genus WELLERIOPSIS Swartz and Whitmore, 1956 \\ Welleriopsis? pustulosa n. sp. \\ Plate 3, figures, 18-23}

Description.-Lateral outline amplete, subrectangular; cardinal angles obtuse; hinge line less than greatest length of shell. Dorsal outline lanceolate. Height slightly more than half length of shell. Prenodal sulcus shallow, broad, short, being clearly defined only in dorsal third of valve. Adductorial sulcus deeper, broad, extends half or slightly more than half height of valve. Anterior lobe relatively broad, cuspate dorsally, protruding above hinge line. Preadductorial lobe small, subglobular to subovate, set well below hinge line. Syllobium broad, broadly cuspate dorsally. An indistinct zygal ridge is developed beneath the preadductorial lobe and adductorial sulcus. Velar ridge narrow, separated from domicilium by a shallow groove. Ventral surface channeled on both valves. Small denticles around free margins of both valves.

Surface covered with indistinct pustules on which is superimposed a fine granulation. This ornamentation covers surface of domicilium except for sulci.

Heteromorph similar to tecnomorph except that height is relatively greater; valve is inflated so that preadductorial lobe is isolated and velar ridge is obscured, but not obliterated, by inflation of valve.

The dimensions of a large tecnomorph are $3.1 \mathrm{~mm}$ in length and $1.75 \mathrm{~mm}$ in height. The heteromorph is 3.3 $\mathrm{mm}$ in length and $2.2 \mathrm{~mm}$ in height.

Types.-Holotype, USNM 162296 ; paratypes, USNM 162294, USNM 162294a, USNM 162295, YPM 23844.

Discussion.-This species is questionably assigned to Welleriopsis because of the character of the presumed heteromorph. Only one heteromorphic valve has been found as yet, and this specimen does not show as pronounced a cruminal inflation as is illustrated by Swartz and Whitmore $(1956$, pl. 105, figs. 10, 11) for W. diplocystulis, the type species of the genus. Furthermore, species assigned to Welleriopsis by Swartz and Whitmore do not seem to have as pronounced cusps on the anterior lobe and syllobium. However, specimens of Welleriopsis from the Coeymans Limestone (Lower Devonian) show a reduced velar ridge crossing the cruminal inflation as in $W$. ? pustulosa, although the cruminal inflation is much more conspicuous in the Early Devonian forms. This species appears to be similar in outline and lobation to the form described as Kloedenia? newbrunswickensis by Copeland (1962, p. 35-36, pl. 8, figs. 1-8) from the Lower Devonian upper Dalhousie beds of New Brunswick, although differing markedly in ornamentation. This relation suggests that this type of ostracode continues fairly high into the Early Devonian. 
Superficially, $W . ?$ pustulosa resembles Tikiopsis denticulata, but no specimens have been found showing the adnate ventral flap characteristic of Tikiopsis, and the sulci are shorter and shallower.

Size of sample.-Seven specimens, including three complete carapaces, were available for study.

Occurrence.-All specimens are from collections at Schoharie (YPM 5244/146, USGS 3393-SD, USGS 8063-SD, USGS 8064-SD). A small tecnomorph with similar ornamentation has been found in the Wilbur Member (Upper Silurian) of the Rondout Limestone of the Hudson Valley (USGS colln. 7999-SD).

\section{Welleriopsis? sp.}

Plate 3, figure 11

Discussion.-Three small tecnomorphs with the general lobation of Welleriopsis have been found in a collection from Shutter Corners (USGS 3390-SD). These are smooth and somewhat resemble Welleriopsis jerseyensis (Weller), but have deeper sulci. The material in hand is not adequate for identification or description. The figured specimen (USNM 162291) is $2.05 \mathrm{~mm}$ long and $1.30 \mathrm{~mm}$ high.

\section{Superfamily DREPANELLACEA Ulrich and Bassler, 1923 Family KIRKBYELLIDAE Sohn, 1961 \\ Kirkbyellid?, gen. and sp. indet. Plate 6, figure 15}

Discussion.-A single left valve of a coarsely reticulate ostracode has been found at Schoharie (USGS 8064$\mathrm{SD)}$. The posterior part of the specimen is broken, but the pattern of the reticulations on the ventral part of the valve suggests that there may have been a backwardpointing projection, as in Kirkbyella. However, unlike that genus the specimen is distinctly bisulcate. The straight hinge line, subquadrate outline, lack of velar structures, and indication of a posterior spur suggest that this specimen is a kirkbyellid, although it cannot be assigned to any described genus. The broken specimen is 0.80 of a mm long and 0.45 of a mm high.

\section{Superfamily HOLLINACEA Swartz, 1936 Family HOLLINIDAE Swartz, 1936 \\ Hollinid?, gen. and sp. indet. Plate 6, figure 14}

Discussion.-One left valve, broken anteriorly, which differs markedly from other Cobleskill ostracodes, has been found in a collection from Schoharie (USGS 8064$\mathrm{SD}$ ). The specimen is velate; the velum is tubulous and extends posteriorly to just behind the median sulcus. The median sulcus is distinct and extends more than half the height of the valve excluding the velum. The median lobe is small and oval; the anterior sulcus is indistinct.
On the dorsoposterior side of the median sulcus there is a small rounded knob. This specimen may represent a hollinid allied to Parabolbina or Triemilomatella, but there is no indication of loculi on the ventral surface of the valve. As only one specimen has been found, it is impossible to assign it to a genus, or even to be sure that it is a hollinid, as it might possibly be an amphitoxotidine beyrichiacean, although the velum is more restricted than is usual in that group. The specimen is 0.80 of a $\mathrm{mm}$ long and 0.50 of a mm high.

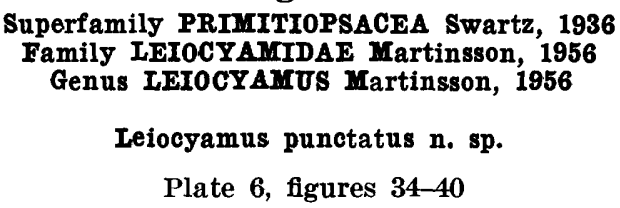

Description.-Lateral outline amplete, subovate ; dorsal outline of tecnomorphs lanceolate, of heteromorphs lanceolate with a chevron-shaped reentrant at the posterior end. Hinge straight, incised; dorsum gently curved; ends and ventral margin evenly curved. Position of maximum length median; position of maximum width in posterior third of shell ; position of maximum height median. Right valve markedly overlaps left along free margins. No velar structure in tecnomorphs; velar structure confined to dolon of heteromorphs. Small tubercles present around free margins of both valves.

Shell surface, including dolonal flanges, completely covered with small, circular punctae except for a round, smooth area in the center of each valve. The inner surfaces of the dolon are smooth. Dolonal flanges short, stout, not extending forward on ventral margin of valve beyond about one-third of the length.

Both valves have a faint raised round area in the interior beneath the smooth spot on the exterior. The hinge of the right valve has a groove for the reception of the sharp edge of the left valve. Both valves have distinct indentations at either end of the hinge.

The dimensions of a representative heteromorph are 0.98 of a mm in length, 0.71 of a $\mathrm{mm}$ in height, and 0.48 of a mm in width.

Types.-Holotype, YPM 23840; paratypes, YPM 23837-23839, YPM 23841, USNM 162365, 162366.

Discussion.-This species has been assigned to Leiocyamus because the dolon does not form an enclosed chamber and the lateral surface of the valves is not sulcate. Martinsson (1956, p. 30), in his diagnosis of the genus, stated that the dolon was extended forward along the ventral side of the valve. This feature is poorly developed in $L$. punctatus, the dolon being largely confined to the posterior end of the shell and 
not extending beyond the midpoint even on the right valve, where it is best developed. This species also differs from the type species, L. apicatus Martinsson, 1956, in having a less prominent dorsal ridge which does not rise to a point, so that superficially the two species appear quite different. However, the absence of sulcation and the open dolon are considered sufficient for the generic assignment.

The primitiopsids are abundant in the Silurian of Europe; but, to date, only one genus, Limbinaria Swartz and Whitmore, 1956, has been reported from the Silurian of North America. The occurrence of this additional European genus in the North American Silurian is therefore of considerable interest.

Size of sample.-More than 50 specimens were available for study.

Occurrence.-Moderately abundant in collections from Schoharie, N.Y. (YPM 5244/146, USGS 3393SD, USGS 7283-SD) and has also been found in collections from Jerusalem Hill (YPM 2594), Howes Cave (USGS 8065-SD), near Central Bridge (USGS 7198SD), and Shutter Corners (USGS 3390-SD). A very similar form, perhaps conspecific, occurs in a collection from the Decker Limestone of Pennsylvania at Shawnee on Delaware (USGS 5839-SD).

\section{Leiocyamus sp. A}

Plate 6, figures 47,48

Discussion.-One heteromorphic carapace from Shutter Corners (YPM colln. 5244/150) is nearly twice as large as specimens of $L$. punctatus from Schoharie and Jerusalem Hill, measuring $1.83 \mathrm{~mm}$ in length, $1.15 \mathrm{~mm}$ in height, and $1.01 \mathrm{~mm}$ in width. It also differs from typical specimens of $L$. punctatus in having a large inflated area in the central part of each valve and in having a rounded rather than subangular dorsal ridge. This probably represents a different species, but as only one specimen is available for study, it does not seem desirable to propose a name for it at the present time.

Leiocyamus sp. B

Plate 6, figures 45,46

Discussion.-A crushed heteromorphic carapace and one right and one left valve have been found that differ from Leiocyamus punctatus. These specimens have a wider dolon that is distinctly set off from the domicilium and extends farther forward than that of L. punctatus. Furthermore, in these specimens the dorsum is narrow and the hinge line is not deeply incised. The ornamentation is punctate, but the punctate appear to be finer on the dolon. These specimens may represent yet another species of Leiocyamus, or may be a variant of $L$. punctatus. The material at hand is inadequate for determination at this time.

The specimens are from Schoharie, N.Y. (USGS colln. 3393-SD, USGS colln. 7283-SD). A broken specimen from Prospect Hill (USGS colln. 5207-SD) has the same characters as the specimens from Schoharie. A left valve is $1.20 \mathrm{~mm}$ in length and 0.70 of a mm in height. A crushed carapace is $1.20 \mathrm{~mm}$ in length and 0.75 of a $\mathrm{mm}$ in height.

\section{Family PRIMITIOPSIDAE Swartz, 1936 Genus PRIMITIOPSIS Jones, 1887 \\ Primitiopsis? sp. \\ Plate 6, figure 44}

Discussion.-A single tecnomorphic carapace of a sulcate primitiopsid has been found at Schoharie, N.Y., (USGS colln. 8062-SD). The specimen is fairly coarsely reticulated except for the ventral surfaces of both valves, which form smooth lips. No denticles have been seen along the contact margins, but their absence may be due to the type of preservation. The median sulcus extends slightly less than half the height of the valves, and although its ventral end is wider it does not end in a distinct pit as in Primitiopsis s.s. This specimen is tentatively assigned to Primitiopsis, although until heteromorphic specimens are found it will not be possible to determine whether true Primitiopsis is present in the Cobleskill fauna. The specimen is $1.15 \mathrm{~mm}$ long and 0.65 of a $\mathrm{mm}$ high.

\section{Family uncertain \\ Genus HALIIELIA Ulrich, 1891 \\ Halliella? sp. \\ Plate 6, figure 16}

Discussion.-A single incomplete valve of a reticulated unisulcate ostracode has been found in USGS collection 7283-SD from Schoharie, N.Y. Slightly more than half the valve is preserved, which is enough to show that the specimen was relatively long in proportion to its height; it has a subrectangular outline and a deep median sulcus which is broad ventrally, like an inverted keyhole. The reticulations extend to the edge of the valve, which overhangs the contact margin, but there is apparently no velate structure. The specimen is here tentatively listed as Halliella?, but it may be an early kirkbyacean. It is illustrated to call attention to this type of ostracode in the Cobleskill fauna. The broken specimen is 0.60 of a mm long and 0.40 of a mm high. 
Order KLOEDENELIICOPIDA Scott, 1961 Superfamily KLOEDENELLACEA Ulrich and Bassler, 1908 Family KLOEDENELLIDAE Ulrich and Bassler, 1908

Genus DIZYGOPLEURA Ulrich and Bassler, 1923

Diagnosis.-Trisulcate kloedenellids with left valve overlapping right valve, and bearing a narrow stragular process above $\mathbf{S} 1$ which fits into a deep narrow notch in right valve.

Discussion.-The above diagnosis differs from that given by Sohn (in Moore, 1961, p. Q182) in including reference to the type of stragular process. This structure, named and discussed by Guber and Jaanusson $(1964$, p. 2-5), appears to be quite different in the otherwise similar genera Dizygopleura and Poloniella. In Dizygopleura, the stragular process is narrow, linguiform, and fits into a distinct notch in the right valve. In Poloniella, the stragular process is wide, as much as one-fourth of the length of the hinge line, and is not clearly set off from the hinge line. Adamczak (1961, p. 295) recognized the differences in hingement between Dizygopleura and Poloniella, as represented by Poloniella devonica Gürich, 1896, but he did not consider them significant. He considered (Adamczak, 1961, p. 295) Dizygopleura to be a junior synonym of Poloniella.

Adamczak (1961) based this conclusion on the similarities of hingement and lobation in the two genera, and on the ontogenetic development of Poloniella devonica and several other species which he assigned to Poloniella. As discussed above, the hingement of $P$. devonica differs from that of Dizygopleura swartzi Ulrich and Bassler, 1923, the type species of Dizygopleura, in the character of the stragular process. Dizygopleura characteristically is trilobate, with $\mathrm{S} 1$ and $\mathrm{S} 3 \mathrm{long}$, extending more than two-thirds the height of the shell and S2 relatively short. Poloniella is also trilobate, but $\mathrm{S} 1$ and S3 join beneath S2. There is little difficulty distinguishing typical Dizygopleura from Poloniella on the basis of lobation, but in several species, here considered Dizygopleura, S3 curves anteriorly undor S2 and is represented by one or more ventral pits. Two species that have two ventral pits are $D$. costata Ulrich and Bassler, 1923, and D. hieroglyphica (Krause, 1891 ) ; the latter is much discussed in controversies over the relationship of Dizygopleura and Poloniella. Two species that have one ventral pit are $D$. unipunctata (Ulrich and Bassler, 1923) and D. monostigma, n. sp. These species and others-such as D. angustisulcata Swartz and Whitmore, 1956, in which S3 is almost obsolete so that the species verges on Kloedenellasuggest that sulcation is gradational in kloedenellids and may be a difficult character to use for generic distinctions.
Adamczak (1961, p. 287-289, pl. 1) discussed and illustrated two species, Poloniella tertia Krommelbein, 1953 and $P$. diversa Adamczak, 1961, which have juveniles as large as adult -2 with Poloniella-like sulcation and adults with sulcation like that of Dizygopleura. This relation would seem to give support to the synonymy of Dizygopleura with Poloniella, and would suggest that the Poloniella type of sulcation is the more primitive. However, typical Dizygopleura appears in the Middle Silurian, whereas Poloniella s.s. is, as far as known, restricted to the Devonian. Furthermore, Lundin (1965, pl. 10, figs. 3a-q) has illustrated immature instars of Dizygopleura landesi as young as adult -4 , which have typical sulcation of the Dizygopleura type; the same is true of immature specimens of $D$. hallii illustrated in this paper (pl. 5, figs. 21-23). Possibly the adults illustrated by Adamczak represent convergent evolution in Poloniella, or perhaps they do not belong with the immature tecnomorphs as figured.

Although Adamczak has demonstrated that Dizygopleura and Poloniella are closely related, it is questionable whether they are more closely related than Dizygopleura and Kloedenella are. Dizygopleura and Poloniella differ more in the character of the stragular process than do Dizygopleura and Kloedenella. Rocently, Weyant (1968, p. 100-101) has suggested that Dizygopleura should be considered a subgenus of Poloniella, and has also described a new subgenus, Framella, of Poloniella. The stragular process of Framella Weyant, 1968, pl. 2, figs. 8,9) appears to be close to that of Poloniella, which suggests that Framella may be correctly assigned as a subgenus of Poloniella. However, the narrow stragular process and deep stragular notch of Dizygopleura are here considered sufficiently distinctive to warrant retaining Dizygopleura as a separate genus, pending further study of the North American Silurian species as recommended by Weyant (1968, p. 101). This retention seems especially desirable in view of the different geographic and stratigraphic occurrences of Dizygopleura and Poloniella.

\section{Dizygopleura hallii (Jones)}

Plate 5, figures $20-45$

Beyrichia Hallii Jones, 1890, p. 15, pl. 4, fig. 21.

Beyrichia halli Jones. Ulrich, 1894, p. 669. (listed under Bollia.) Beyrichia Halli Jones. Gürich, 1896, p. 390.

Kloedenella halli (Jones). Ulrich and Bassler, 1908, p. 319, fig. 62, pl. 43, fig. 4; Clarke, 1909, p. 13, 21 ; Grabau and Shimer, 1910, p. 359, text fig. 1663g; Bonnema, 1914, p. 1107 , pl. fig. 6 ; Bassler, 1915, p. 683 ; Kummerow, 1931, p. 158-159.

Poloniella Hallii Jones (sic). Van Veen, 1921, p. 891, fig. 12; 1922, p. 995, fig. 12.

Dizygopleura halli (Jones). Ulrich and Bassler, 1923, p. 696, pl. 62, figs. 24, 25 ; Swartz, 1933, p. 234. 
Dizygopleura hallii (Jones). Bassler and Kellett, 1934, p. 290 ; Warthin, 1937, card 58.

Beyrichia Clarkei Jones, 1890, p. 17, text fig. 2.

Beyrichia clarki Jones. Ulrich, 1894, p. 669.

Kloedenella clarkei (Jones). Ulrich and Bassler, 1908, p. 319, 320 ; 1913, p. 533, pl. 97, fig. 21 ; Bassler, 1915, p. 683.

Dizygopleura clarkei (Jones). Ulrich and Bassler, 1923, p. 698, pl. 62, figs. 31, 32 ; Swartz, 1933, p. 233-234; Bassler and Kellett, 1934, p. 289; Warthin, 1937, card 58.

Dizygopleura cf. D. clarkei (Jones). Swartz and Whitmore, 1956, p. 1086-1087, pl. 109, figs. 26, 27.

Description.-Lateral outline preplete to amplete, subelliptical to subrhomboidal; dorsal outline indented subfusiform. Anterior margin smoothly rounded; ventral margin sinuate, rarely convex; posterior margin curved, meeting sinuate dorsal margin at an obtuse angle. Stragular process narrow, prominently humped. Hinge line slightly incised behind stragular process so that narrow, triangular dorsal border surfaces are formed on the posterior part of each valve. Stragular process and corresponding notch at dorsal end of S1. S1 long, straight to slightly concave posteriorly, relatively deep. S2 wider, deeper, extends about onehalf height of valve, curves slightly toward anterior. S3 about same height and width as $\mathrm{S} 1$; ventral end curved anteriorly. Lobes about twice width of sulci. Posterior margin of L4 convex toward posterior, separated from posterior margin by indented triangular area in tecnomorphs. Posteroventral keel present on some specimens. Heteromorph differs from tecnomorph in wider L4, slight inflation of posterior triangular area, and narrower S3. Shell surface smooth.

According to my measurements the holotype of Dizygopleura hallii is $1.30 \mathrm{~mm}$ in length and 0.75 of a $\mathrm{mm}$ in height. The holotype of $D$. clarke $i$ is also $1.30 \mathrm{~mm}$ in length and 0.75 of a mm in height. Measurements of specimens from Schoharie, N.Y., are shown in figure 6.

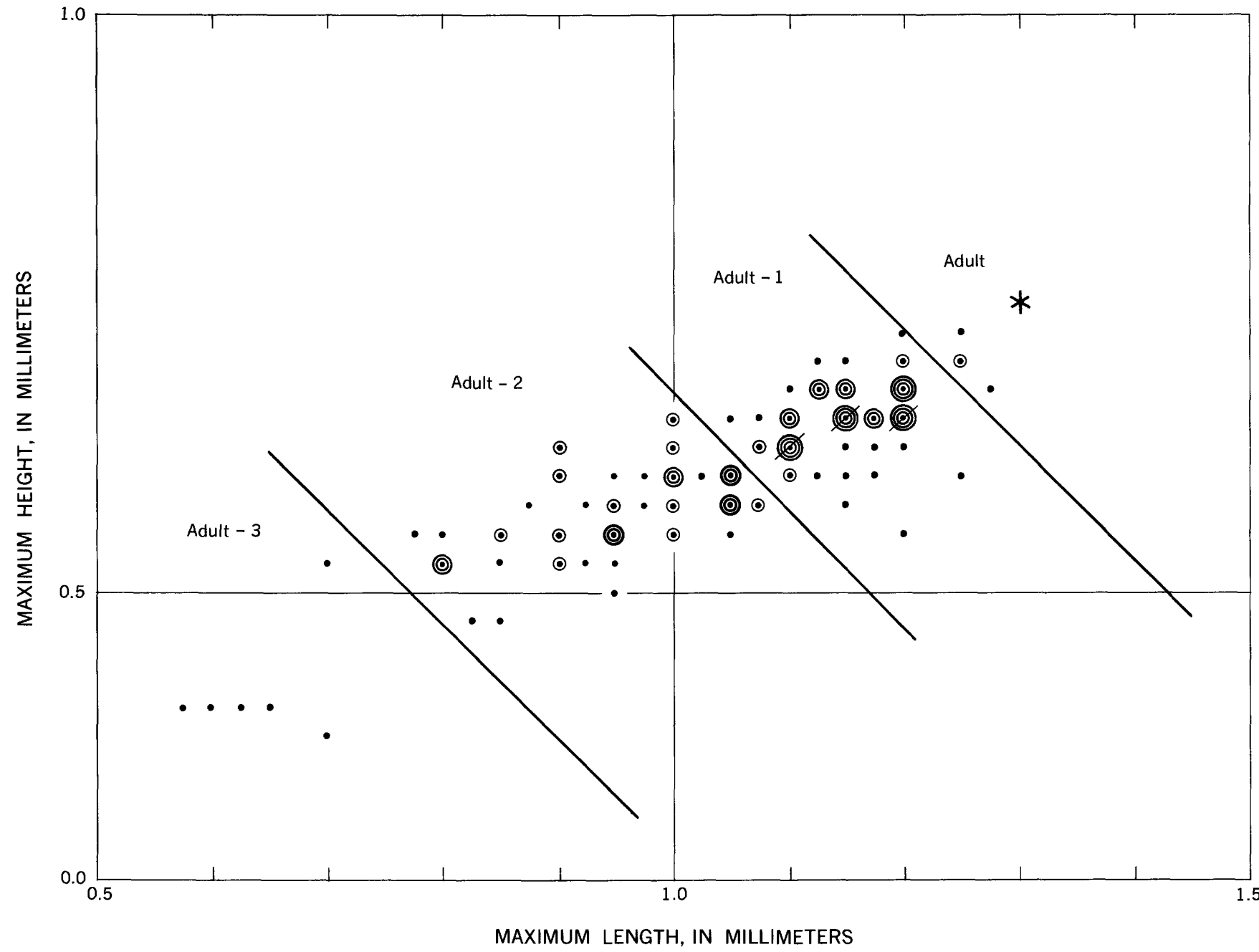

FIGURE 6.-Scatter diagram of maximum length versus maximum height for 120 carapaces of Dizygopleura hallii (Jones) from Schoharie, N.Y. (USGS 3393-SD). Measurements made on left valve. Each circle concentric about a point indicates an additional specimen with the same measurements, five or more specimens being indicated by a slash through the circles. *, indicates measurements of holotype. 
Types.-Holotype of Dizygopleura halli is BMNH In 35128 ; holotype of D. clarke $i$ is NYSM 4141 ; plesiotypes of $D$. hallii are USNM 162330-162345, YPM 23827.

Discussion.-Jones $(1890$, p. 15$)$ described Dizygopleura hallii from a specimen on a small slab of rock which was sent to him by John M. Clarke, who presumably wrote Jones that it came from the "Waterlime Group," from near Utica, N.Y. Jones (1890, p. 15) stated that the limestone was "Largely composed of small organisms, especially Kloedenia notata, with small Brachiopods, etc." This slab, BMNH In 35128, was kindly loaned to me by Dr. R. H. Bate of the British Museum (Natural History). As noted under the discussion of Kloedeniopsis hartnageli n. sp., the ostracodes identified by Jones as "Kloedenia notata" are here assigned to $K$. hartnageli, and the associated brachiopods include Morinorhynchus? interstriatus, Howellella corallinensis eriensis, and Protathyris sulcata, all species characteristic of the Cobleskill Limestone. None of these species occurs in the younger Manlius Limestone, and consequently it seems reasonable to conclude that the slab from which Jones described $D$. hallii came from the Cobleskill rather than from the Manlius as stated by Ulrich and Bassler (1923, p. 697), Bassler and Kellett $(1934$, p. 290$)$, and Warthin (1937, card 58). As noted under the discussion of Protathyris sulcata, the "Waterlime Group" of Vanuxem (1842) included both the Cobleskill and Manlius Limestones.

In the same paper in which he described $D$. hallii Jones $(1890$, p. 17) described Dizygopleura clarkei from a drawing sent to him by J. M. Clarke, which he illustrated as a woodcut (Jones, 1890, p. 17, fig. 2). He probably never saw the actual specimen. Dr. Bruce Bell has kindly loaned me a specimen (NYSM 4141) from the New York State Museum which is labeled "Beyrichia clarkei Jones, type" and which is presumably the original from which the drawing was made. This specimen is also on a slab of dolomitic limestone, like that on which is the type of $D$. hallii; and the associated fauna includes the Cobleskill forms Morinorhynchus? interstriatus, Howellella corallinensis subsp. indet., Kloedeniopsis hartnageli, and Leiocyamus sp. A. The slab from the British Museum (BMNH In 35128) has been compared with the slab from the New York State Museum, and although similar in lithology and fauna they were not originally parts of the same piece of rock. However, the slab from the New York State Museum, like that from the British Museum, undoubtedly also came from the Cobleskill Limestone.

Jones $(1890$, p. 17$)$, presumably quoting information provided by Clarke, stated that Dizygopleura clarkei was "associated with Beyrichia oculina and B. notata- ventricosa in the Lower-Helderberg Group of Herkimer Co., N.Y." Although it is not known when Clarke sent the drawing of $D$. clarkei to Jones, it seems probable that it was before he excluded the Waterlime Group from the Lower Helderberg Group in 1889 (Berdan, 1964, p. B4-B5). Ulrich and Bassler (1913, p. 533, 534) mentioned $D$. clarke $i$ as occurring in the Keyser Limestone at Cumberland, Md., and stated that the type is from Herkimer County, N.Y. Later, however, Ulrich and Bassler (1923, p. 698, 699, pl. 62, fig. 32) redescribed and reillustrated the type and stated that it occurs in "the Lower (typical) Manlius of Schoharie County, New York." They noted that D. hallii, Zygobeyrichia regina Ulrich and Bassler, 1923, and a new species occur with it. At the time Ulrich and Bassler were writing, the Cobleskill was considered the basal member of the Manlius, but their statement that $D$. clarkei occurs in the "typical" Manlius excludes the Cobleskill. Ulrich must have examined the type of $D$. clarkei, for a note with the type specimen in the New York State Museum appears to be in his handwriting and lists the associated fauna as given in Ulrich and Bassler (1923). Unfortunately, their remarks of 1923 concerning the horizon and locality from which the type came have led all subsequent workers to conclude erroneously that Dizygopleura clarkei belongs in the Manlius, not the Cobleskill.

Swartz (1933, p. 233, 234) suggested that D. clarkei might be the female dimorph of $D$. hallii, and this suggestion was accepted by Warthin (1937, card 58), who refigured Jones' original illustrations of both species in his discussion of $D$. hallii. The holotype specimens of both species (pl. 5, figs. 44, 45) are heteromorphic left valves which appear to be conspecific. Consequently, $D$. clarkei is here considered to be a junior synonym of $D$. hallii.

More than 500 specimens believed to be conspecific with the holotype of $D$. hallii have been found in the collections from Schoharie, N.Y.; these have a narrow $\mathrm{L} 4$, are slightly smaller than the type, and are considered to be tecnomorphs. To date, only one corroded carapace has been found in these collections which may represent a heteromorph. A possible explanation for this anomalous situation is that the adults did not occupy precisely the same habitat as the juveniles.

As interpreted in this paper, Dizygopleura hallii is a highly variable species, especially as regards the width and depth of the sulci. In particular, S3 may be shallow and narrow (pl. 5, figs. 30-32) or wide and deep (pl. 5, figs. 33-35, 37, 38). Specimens from Schoharie, N.Y., represent both extremes, and could be assigned to two different species; however, the presence of intermediate forms, including the holotype, makes it difficult to recog- 
nize any consistent distinctions between the end members of the series. Possibly future studies on additional material will demonstrate the presence of more than one species in the group of specimens here considered as Dizygopleura halli; if so, some of these specimens might be assigned to $D$. angustisulcata Swartz and Whitmore, 1956 , but this assignment will depend upon restudy of the type of this species together with the accumulation of an ontogenetic series to determine whether the species are distinct. Dizygopleura angustisculcata appears to have a more narrow S3 than any of the forms here included in D. hallii, and as it occurs in the upper part of the Decker Limestone of New Jersey, it may be slightly younger than typical $D$. hallii.

The syntypes of Dizygopleura hallii obscura Ulrich and Bassler, 1923 (USNM 63654), have a short, shallow, and narrow $\mathrm{S} 3$, and appear to represent a separate species. D. hallii obscura is from the lower Tonoloway Limestone at Keyser, W. Va., and is presumably older than D. hallii.

The holotype of Dizygopleura clarkei paupera Ulrich and Bassler, 1908 (USNM 53280) from the Keyser Limestone in Maryland, has been refigured on plate 5, figure 17. The specimen is a broken carapace, probably of an immature instar, with S2 wide and deep and little indication of a posterior flange. S1 and S3 are filled with matrix on both valves, which may account for the mention of papillae in the sulci in the original description (Ulrich and Bassler, 1908, p. 320). Although the interior and posterior sulci are filled, their course can be distinguished, and they are more vertical than shown in the original illustration (Ulrich and Bassler, 1908, pl. 43, fig. 5). Until additional topotype material can be found and studied, this taxon should be considered a nomen dubium.

Size of sample.-More than 500 carapaces of Dizygopleura hallii were available for study, of which 120 have been measured (fig. 5).

Occurrence.-This species has been found in collections from Shutter Corners (USGS 3390-SD), Schoharie (USGS 3393-SD, USGS 7283-SD, USGS 8063SD, YPM 5244/146), near Central Bridge (USGS 7198-SD), Howes Cave (USGS 8065-SD), Jerusalem Hill (YPM 2594), Forge Hollow (YPM 5244/90B), Prospect Hill (USGS 5207-SD), and Aurelius Station (YPM 5244/14). The type specimen is identified only as coming from Herkimer County, N.Y.

\section{Dizygopleura monostigma n. sp.}

Plate 5, figures 1-12; figure 7

Description.-Lateral outline amplete to preplete, subrhomboidal; dorsal outline indented fusiform. Anterior margin rounded; ventral margin slightly sinuate; posterior margin curved upward, meeting sinuate dorsal margin at an obtuse angle. Dorsal margin straighter in small instars. Stragular process narrow, humped, fits into deep notch in right valve. Hinge line slightly entrenched posteriorly so that narrow triangular border surfaces occur on the posterior part of both valves. S1 deep, long, curved posteriorly, situated beneath stragular process, extends nearly the entire height of valves. S2 wider, shorter, curved strongly anteriorly, extends only about half the height of valves. S3 about same width and depth as S1, curves strongly anteriorly and either extends beneath $\mathrm{S} 2$ or is represented by a distinct laterally elongated pit beneath $\mathrm{S} 2$. Lobes subequal in width; L2 distinctly bulbous in lateral outline although not extending above surface of valves. Posterior edge of L4 convex toward posterior, separated from posterior margin of valve by indented flange about equal to it in width. This flange is somewhat inflated in heteromorphs, so that in dorsal view the outline is straight from posterior edge of $\mathrm{L} 4$ to posterior margin, whereas in tecnomorphs the outline is indented. Shell surface smooth.

A typical adult specimen, the holotype, is $1.35 \mathrm{~mm}$ in length and 0.70 of a $\mathrm{mm}$ in height. For range of dimensions in immature instars see figure 7.

Types.-Holotype, USNM 162323 ; paratypes, USNM 162320, USNM 162324.

Discussion.-This species is associated with Dizygopleura hallii at Schoharie, N.Y., and was at first considered to be a variant of $D$. hallii. However, the presence of small specimens showing the characteristic pit beneath S2 suggests that Dizygopleura monostigma should be recognized as a separate species. D. monostigma has also been found in the Keyser Limestone about 5-10 feet above a ledge that contains Gypidula prognostica Maynard, 1913, in an old quarry just west of La Vale, Md. (USGS 8125-SD), which is included in the old Cash Valley section of the Maryland Survey Lower Devonian volume. (See Ulrich and Bassler, 1913.) The Maryland specimens attain a greater size than do those from Schoharie, and the large specimens are dimorphic; apparently none of the Schoharie specimens are adults. Accordingly, the holotype and paratypes have been selected from USGS 8125-SD) from Maryland. The specimens from Schoharie show more variability in S3 than do those from Maryland, as in some specimens the subcentral pit appears to connect directly with this sulcus and be an extension of it. Also, the Schoharie specimens tend to be somewhat longer in proportion to their height, as shown in figure 7. Probably not more than three instars are present in the 


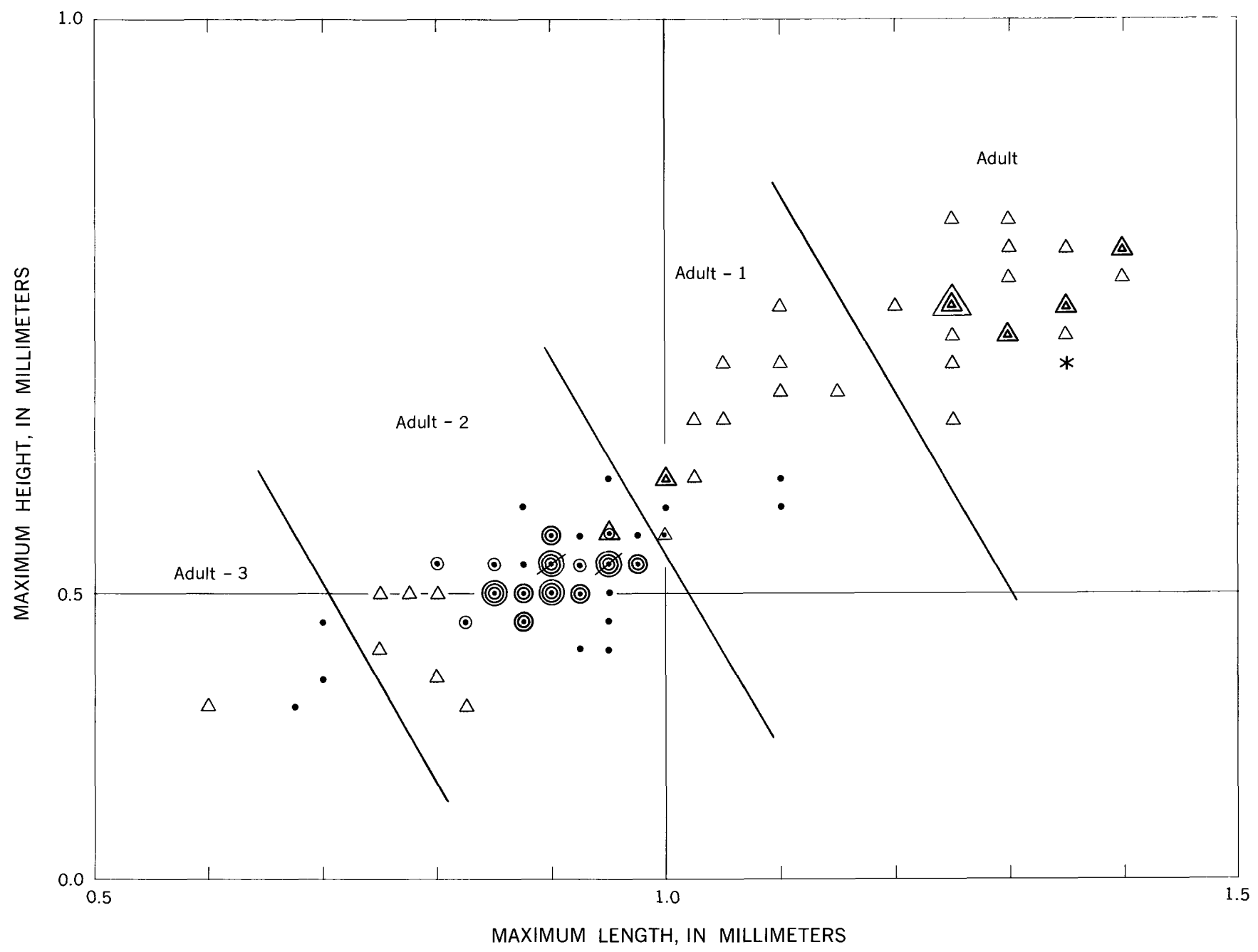

Figure 7.-Scatter diagram of maximum length versus maximum height for Dizygopleura monostigma $\mathrm{n}$. sp.; 60 carapaces from Schoharie, N.Y., and 40 specimens from the Keyser Limestone just above the Gypidula prognostica Zone, Cash Valley Road, La Vale, Md. (USGS 8125-SD). Specimens from Schoharie shown by points or concentric circles, each circle concentric about a point representing an additional specimen with identical measurements; specimens from La Vale shown by triangles; a slash through concentric circles indicates five or more specimens. *, indicates measurements of holotype.

Schoharie collections, as compared to four (including the adults) in the Maryland collection. Perhaps, as suggested for Dizygopleura hallii, the adults of $D$. monostigma may have lived in a different habitat in the Schoharie area.

Dizygopleura monostigma differs from $D$. unipunctata Ulrich and Bassler, 1923, in having the ventromedian pit elongated horizontally rather than vertically as in the latter species.

Size of sample.-More than 200 specimens were available for study, of which 100 were measured.

Occurrence. - D. monostigma has been found in collections from Schoharie, N.Y. (USGS 3393-SD, USGS 7283-SD, USGS 8063-SD, YPM 5244/146), and just west of La Vale, Md. (USGS 8125-SD).
Dizygopleura costata Ulrich and Bassler

Plate 5, figures 13-16

Dizygopleura costata Ulrich and Bassler, 1923, p. 700, pl. 60, figs. 23, 24.

Description.-Lateral outline kloedenelliform; dorsal outline indented subtrapezoidal. Anterior margin rounded; ventral margin sinuate; posterior margin obtusely angulate; dorsal margin nearly straight. Stragular process narrow, on left valve dorsal to $\mathrm{L} 1$ and $\mathrm{S} 1$, on right valve dorsal to $\mathrm{S} 1$; hump not prominent. Hinge line slightly incised; narrow, triangular dorsal border surfaces on each valve. Sulci wide, deep; lobes narrow, giving carapace an emaciated appearance. S1 and S3 extend entire height of shell; S2 extends about two-thirds of distance from dorsal to ventral margin. 
Beneath S2 is a pit, and between $\mathrm{S} 2$ and $\mathrm{S} 3$ is another pit. Lobes narrow, not much wider than sulci, cristate. L4 narrow, separated from posterior end of shell by depressed flange in tecnomorphs. Heteromorph with only slightly more thick posterior flange. Shell surface smooth in sulci and on posterior flange, appears slightly punctate on lobes.

A representative adult specimen measures 0.92 of a $\mathrm{mm}$ in length and 0.47 of a mm in height.

Types.-Lectotype, USNM 162325, the original of figure 23 , plate 60 of Ulrich and Bassler (1923). The paralectotype is USNM 63677, the original of figure 24, plate 60 of Ulrich and Bassler (1923).

Discussion.-This distinctive species may be recognized by the two ventral pits beneath $\mathrm{S} 2$ and the cristate lobes which give the specific name.

Ulrich and Bassler (1923, p. 699-701) included $D$. costata in their "Group of Dizygopleura hieroglyphica (Krause)" and commented on its resemblance to that species. They also included in this group their new species $D$. perrugosa, $D$. virginica, and $D$. unipunctata the characteristic of the group being that the lobes are narrower than the sulci. The illustration of $D$. perrugosa (Ulrich and Bassler, 1923, pl. 60, fig. 26) is somewhat misleading; the holotype (USNM 63678) is a broken right valve of a heteromorph. The anterodorsal angle has apparently broken in front of the stragular notch, so that the humped dorsal outline of the illustration is probably not as extreme as shown. However, the species seems to be distinctive in that $\mathrm{S} 2$ is as long as the other sulci and extends to the ventral margin of the valve. It does not, however, greatly resemble either $D$. hieroglyphica or D. costata. Dizygopleura virginica is represented by four cotypes (USNM 63689) which are internal molds. The lobes seem to be thin relative to the sulci, but because of the type of preservation it is difficult to be sure. Dizygopleura unipunctata also appears to differ somewhat from its description and figures; the holotype (USNM 63685) is a left valve with L2 broken, S1 long and apparently narrow, S2 narrow and extending about halfway to the ventral margin, and S3 fairly broad. The pit beneath $\mathrm{S} 2$ is slightly impressed and vertically elongated. The species seems to be closer to $D$. monostigma than to D. costata.

In summary, of the five species originally assigned to the group of Dizygopleura hieroglyphica (Krause), probably only two, D. hieroglyphica (Krause) and $D$. costata Ulrich and Bassler, are very closely related. Both these species have deep pits beneath S2, narrow stragular processes, deep narrow stragular notches, and a subrectangular outline. The principal difference is that $D$. costata has carinate lobes and $D$. hieroglyphica does not. A third form, identified as Dizygopleura sp. cf. D. costata (Boucot, 1961, p. 181), occurs in the Hardwood Mountain Formation of west-central Maine. This form has carinate lobes like D. costata but has three pits rather than two beneath S2. Possibly it, together with $D$. hieroglyphica and D. costata, should eventually be placed in a new genus.

Size of sample.-Twenty-one specimens were available for study.

Occurrence.-Dizygopleura costata was originally described as occurring in the upper Tonoloway at Keyser, W. Va. In New York, it has been found only in collections from Schoharie (USGS 3393-SD, USGS 7283SD, USGS 8063-SD, YPM 5244/146).

\section{Dizygopleura viafontinalis $n$. sp. Plate 5, figures 18,19}

Description.-Lateral outline amplete, subelliptical. Anterior margin rounded; ventral margin sinuate; posterior margin rounded, meeting sinuate dorsal margin at obtuse angle. Stragular process narrow, small, only slightly humped. S1 narrow, deep, sinuate, with pronounced anterior curve in ventral part. S2 wide, short, not more than half height of valve, curved anteriorly. S3 relatively short, shallow, and narrow, curved anteriorly, begins nearly one-third height of valve below dorsal margin. L1 fairly broad; L2 small, bulbous in lateral outline; L3 broad; L4 not distinctly marked off from posterior border surface. Heteromorph with bulbous inflation of L4. Surface of valves finely punctate, except on bulbous posterior of heteromorph.

The dimensions of the holotype, a heteromorphic left valve, are $1.30 \mathrm{~mm}$ in length and 0.70 of a $\mathrm{mm}$ in height; a crushed tecnomorphic carapace is $1.17 \mathrm{~mm}$ in length and 0.57 of a $\mathrm{mm}$ in height.

The name is derived from the locality on Spring Street, Schoharie, N.Y., where the only specimens have been found.

Types.-Holotype, USNM 162329; paratype, USNM 162328.

Discussion.-This species is so distinctive that a new name for it appears desirable, even though only one crushed tecnomorphic carapace and one heteromorphic left valve have been found. The punctate surface and sigmoidal S1 distinguish it at once from any of the other species of Dizygopleura in the Cobleskill. Other distinctly punctate species of Dizygopleura, such as $D$. punctella Hoskins, 1961, D. ventrisulcata Hoskins, 1961, and D.? pulchella (Ulrich and Bassler, 1923) have punctae in the sulci (Hoskins, 1961, p. 92-96), not on the lobes as in $D$. viafontinalis.

Size of sample.-One carapace and one left valve.

Occurrence.-Only in collections from Schoharie, N.Y. (USGS 3393-SD, USGS 8062-SD). 
Genus KIOEDENELLA Ulrich and Bassler, 1908

Kloedenella sp.

Plate 6, figures $41-43$

Disoussion.-The genus Kloedenella is apparently poorly represented in the Cobleskill Limestone. Nine specimens were available for study, of which four are either crushed or broken. All have a narrow S1 extending below the midheight of the valve, a wider and shorter S2 that extends to about the midheight of the valve, and a sinuous ventral outline. The stragular process is narrow and not humped, so that the dorsal outline in lateral view is straight to gently convex. A figured specimen (pl. 6, figs. 41, 42) is $1.15 \mathrm{~mm}$ in length and 0.65 of a $\mathrm{mm}$ in height.

One specimen from Forge Hollow (YPM 5244/90B) differs from the above description in having a markedly humped stragular process and a relatively greater height in proportion to width. This specimen may not be conspecific with the others. In general appearance it is very close to Kloedenella rectangularis Ulrich and Bassler, 1923, from the lower part of the Tonoloway Limestone at Cumberland, Md., but differs from it in having a sinuous ventral outline. Kloedenella rectangularis, which may be the heteromorph of $K$. obliqua Ulrich and Bassler, 1923, has a round ventral outline and shorter sulci. The specimen from Forge Hollow is even closer to Kloedenella turgida Ulrich and Bassler, 1908, from the Keyser Limestone at Cumberland, but $K$. turgida has a short, poorly defined S1. No other species of Kloedenella seem to be comparable to the specimens from the Cobleskill, but the material available is not considered adequate for description.

Occurrence.-In collections from Schoharie (YPM 5244/146, USGS 3393-SD), Oriskany Falls (YPM 5244/88A), Forge Hollow (YPM 5244/90B) and Prospect Hill )USGS 5207-SD).

Genus EUKLOEDENELLA Ulrich and Bassler, 1923

Eukloedenella? weldae n. sp.

Plate 6, figures 25-29

Description.-Lateral outline subovate; dorsal outline cuneate. Greatest width commonly in posterior quarter of carapace. Small vertically elongated median pit situated slightly anterior to the midpoint in length, slightly dorsal to the midpoint in height. Stragular process elongated parallel to length of shell, extending: about one-third to one-half length of hinge, not raised into prominent hump. Left valve overlaps right along ventral margin and bears stragular process. Right valve without stragular notch. Ventral margin slightly sinuate. Posterior end of both valves of tecnomorph sharply indented so that there appears to be a vertical ridge about one-fifth the length of the shell from the posterior margin in lateral view; in dorsal view the posterior appears compressed. Heteromorphs wider posteriorly so that ridge is not as conspicuous in lateral view, and in dorsal view posterior appears inflated. Shell surface smooth except for median pit.

Interior of left valve shows ridge beneath stragular process, forming groove into which right valve fits. Median pit represented internally by a low, indistinct ridge. Posterior of heteromorph may also have low internal ridge (limen) in some specimens. No stragular notch in right valve.

The dimensions of the holotype are $1.00 \mathrm{~mm}$ in length and 0.55 of a mm in height.

Types.-Holotype, USNM 162361; paratypes USNM 162359, 162360, 162362, 162363.

Discussion.-Eukloedenella? weldae superficially appears very similar to the illustrations of Sulcocavellina? altschedatensis Polenova (1960, pl. 4, figs. 3a, b; $4 \mathrm{a}, \mathrm{b})$, and also resembles various forms assigned to Sulcella Coryell and Sample, 1932, such as Sulcella (Sulcella) kloedenellides Adamczak, 1968. However, it differs from these species in having the left valve overlapping the right and in apparently having kloedenellid rather than a cavellinid hinge structure. Unfortunately, most specimens broke during preparation of the hinge because the species has a rather thin shell, so that the internal features are illustrated only by one left valve (pl. 6, fig. 29). E.? weldae differs from Nynhamella musculimonstrans Adamczak, 1966, which Adamczak $(1966$, p. 14, 15) considered a Kloedenellid, in the overlap of the left valve over the right and in the presence of a pitlike S2 in E.? weldae.

This species is placed questionably in Eukloedenella because it differs from most other species in the genus by the nearly central location and pitlike character of $\mathrm{S} 2$ and the presence of the posterior ridgelike angulation. The closest form to $E$.? weldae is $E$. abrupta Ulrich and Bassler, 1923, from the Drepanellina clarki Zone at McKees Farm, 7 miles west of Lewiston, Pa. The holotype of E. abrupta (USNM 63638) is a tecnomorphic right valve represented by the part and counterpart in shale. The posterior angulation is much more pronounced in this specimen than in E.? weldae, and the area posterior to the angulation is larger.

The 19 species and subspecies assigned to Eukloedenella by Ulrich and Bassler (1923, p. 666) need restudy in the light of modern concepts. For example, Ulrich and Bassler (1923, p. 668-676) divided Eukloedenella into five species groups, but Swartz (1933, p. 258-259) has indicated that two of the species in their group $V$ are probably heteromorphs of a species in their group IV, which includes E. abrupta. The group of $E$. 
sinuata Ulrich and Bassler, 1923 (group III) includes species with a narrower and more prominent stragular process than those in the other groups, one of which is group II, the group of E. umbilicata Ulrich and Bassler, 1923, the type species of the genus. Possibly more than one genus is present in the species now assigned to Eukloedenella, and further study may show that $E$. abrupta and E.? weldae should be assigned to a new genus. However, it seems inadvisable to do this without further study of all the species, which is beyond the scope of this paper.

The species is named for Miss E. A. Weld, who assisted in collecting the material described.

Size of sample.-Seventy-eight complete carapaces and 25 single valves from Schoharie, N.Y., were available for study.

Occurrence.-All specimens studied are from collections made at Schoharie, N.Y. (USGS 3393-SD, USGS 7283-SD, YPM 5244/146), except for three poorly preserved specimens from near Central Bridge, N.Y. (USGS 7198-SD).

\section{Family BEYRICHIOPSIDAE Henningsmoen, 1953 Genus MARGINIA Polenova, 1952 \\ Marginia? sp. \\ Plate 6, figure 17}

Discussion.-One right valve of a weakly bisulcate ostracode has been found in USGS collection 8062-SD from Schoharie. The specimen has a straight hinge line and lacks a stragular process. The surface is covered with fine longitudinal riblets, which tend to anastomose and are approximately parallel to the hinge. The ventral margin has obscure traces of a thin, narrow marginal flange, which is mostly broken. This specimen is very questionably assigned to Marginia because of the character of the ornamentation and ventral margin. The specimen is $1.0 \mathrm{~mm}$ long and 0.5 of a mm high.

Family LEPERDITELLIDAE Ulrich and Bassler, 1906 Genus BONNEPRIMITES Swartz and Whitmore, 1956

Bonneprimites? breviformis Swartz and Whitmore

Plate 6, figures 30-33

Bonneprimites? breviformis Swartz and Whitmore, 1956, p. 10531054, pl. 110, figs. 20-22.

Description.-Lateral outline amplete, hemielliptical to hemicircular; dorsal outline broadly lanceolate. Bisulcate, anterior sulcus very weak and shallow, essentially obsolete; median sulcus short, narrow, extends only about one-fifth distance from dorsal to ventral margin. Obscure muscle(?) spot present at ventral end of median sulcus. Surface of valves very convex; greatest width in posterior third of carapace. Obscure velar(?) bend around entire free margin; hinge line slightly incised. Valves nearly equal, but left valve slightly overlaps right around free margin. Lateral surface of both valves smooth, but ventral surface of domicilium on both valves has very fine striae parallel to the free margin.

The dimensions of a complete carapace are 0.95 of a $\mathrm{mm}$ in length and 0.67 of a mm in height.

Discussion.- Two complete carapaces and a left valve have been found in the Cobleskill which agree with the description and illustrations of Swartz and Whitmore and are consequently assigned to their species. However, as indicated by Swartz and Whitmore (1956, p. 1053$1054), B$.? breviformis is probably not congeneric with the type of the genus, Bonneprimites bonnemai. Unfortunately there is still not enough material to determine the generic or even the familial affinities of this species. Superficially it resembles the primitiopsid genus Scipionis Gailite, 1966, but the ventral marginal structures do not appear to be those of a typical primitiopsid, and no heteromorphs have as yet been found.

Size of sample.-Three specimens were available for study.

Occurrence.-Found only at Shutter Corners (USGS $3390-S D)$.

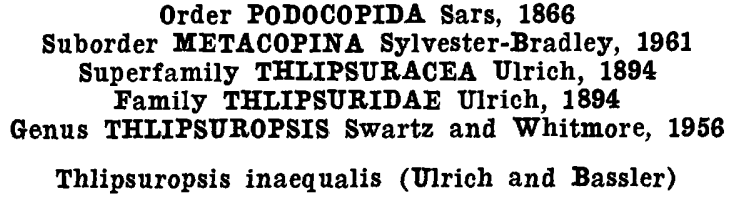

Order PODOCOPIDA Sars, 1866 Suborder METACOPINA Sylvester-Bradley, 1961 Superfamily THIIPSURACEA Ulrich, 1894 Family THLIPSURIDAE Ulrich, 1894 Genus THIIPSUROPSIS Swartz and Whitmore, 1956

Thlipsuropsis inaequalis (Ulrich and Bassler)

Plate 6, figures 4-7

Octonaria inaequalis Ulrich and Bassler, 1913, p. 538, pl. 98, figs 12-18.

Thlipsuropsis inaequalis (Ulrich and Bassler). Lundin, 1965, p. 78-79, pl. 18, figs. 1a-j, text fig. 45.

?Thlipsuropsis longisulcata Swartz and Whitmore, 1956, p. 1088, pl. 110, figs. 14, 15.

Description.-Lateral outline subovate; dorsal margin of larger left valve strongly arched; anterior margin sharply curved; ventral margin nearly straight; posterior margin broadly curved. Lateral outline of smaller right valve subovate to reniform. Dorsal outline subovate to subrectangular, acuminate on both ends. Valves markedly unequal, left valve overlapping right around free margins and overreaching along hinge. Axes of maximum height and length pass about through midpoint of valve; maximum width in posterior half of carapace.

Left valve ornamented by three distinct, conspicuous grooves, which tend to merge in posterior part of shell: one running parallel to the anterodorsal margin which bifurcates dorsally, leaving a thin ridge between its two branches; one ventral to it in central part of valve, short and broad; and one longer below this ', arallel to 
ventral margin. An indistinct groove below this separates lowest ridge from edge of valve.

Right valve ornamented by three grooves: one subparallel to anterodorsal margin; one shorter groove parallel to posterodorsal margin; and one longer groove ventral to this and diverging from it at an angle.

The dimensions of an average carapace are 0.70 of a $\mathrm{mm}$ in length, 0.50 of a $\mathrm{mm}$ in height, and 0.35 of a $\mathrm{mm}$ in width.

Discussion.-There do not appear to be any significant differences between the specimens from the Cobleskill and the syntypes of Octonaria inaequalis Ulrich and Bassler (USNM 53284) from the Keyser Limestone at Cumberland, Md. This is apparently a fairly long ranging and widely distributed species, for Lundin $(1965$, p. 78-79) has described and illustrated specimens from the Henryhouse Formation (lower Ludlow) of Oklahoma. As Lundin (1965, p. 79) has noted, Thlipsuropsis longisulcata Swartz and Whitmore is probably conspecific with $T$. inaequalis; but because $T$. longisulcata is based only on right valves, its relationship cannot be determined until additional material is obtained. To date, no specimens of Thlipsuropsis have been found in our collections of the Decker, so the point remains unsettled.

Size of sample.-Twenty-six carapaces and three single valves were available for study.

Occurrence.-All specimens came from collections from Schoharie, N.Y. (YPM 5244/146, USGS 3393SD, USGS 7283-SD).

\section{Genus THLIPSURELLA Swartz, 1932 \\ Thlipsurella parva n. sp. \\ Plate 6, figures 1-3}

Description.-Lateral outline suboval, elongate; dorsal outline cuneate. Left valve overlaps right around free margins and overreaches right along hinge. Surface of both valves marked with three small pits; one nearly central, slightly elongated vertically, slightly dorsal to the midpoint of the valves; the other two in posterior third of valves, tending to be slightly elongated horizontally, but nearly round. Posterior of both valves compressed or truncated so that there is a narrow marginal shelf. Anterior of both valves also compressed, but not as sharply, forming an indistinct marginal flange. Axis of maximum height passes through midpoint of shell; axis of maximum length passes through or slightly below midpoint; axis of maximum width is in posterior fifth of shell.

Material inadequate for examination of hinge and interior of shell, but one left valve shows a boss internally as a reflection of the external median pit.
The dimensions of an average specimen are 0.60 of a $\mathrm{mm}$ in length, 0.35 of a $\mathrm{mm}$ in height, and 0.25 of a $\mathrm{mm}$ in width. All specimens appear to be adults.

Types.-Holotype, USNM 162346; paratypes, USNM 162347, USNM 162347a.

Discussion.-This small species most closely resembles Thlipsurella ellipsoclefta Swartz, 1932, the type species of the genus, but lacks the small pit anterior to the median pit, and also differs in having the pits nearly circular rather than noticeably elongated. The specific name refers to the small size of the species.

Size of sample.-Twenty-nine carapaces and one left valve were available for study.

Occurrence.-All specimens are from collections from Schoharie, N.Y. (YPM 5244/146, USGS 3393-SD, USGS 7283-SD).

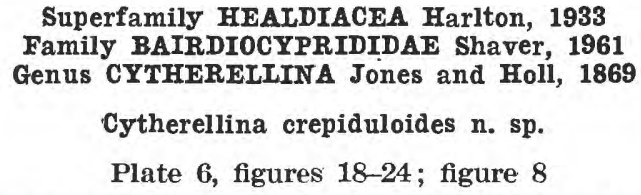

Description.-Carapace subovate in lateral and dorsal outline, subcircular in end view. Dorsal margin evenly curved; anterior margin sharply curved; ventral margin nearly straight to slightly concave; posterior margin curved less sharply than anterior margin. Height about one-half length. Axes of maximum height and maximum length pass through midpoint of carapace; maximum width in posterior third. Left valve overlaps right valve markedly on ventral margin, slightly overreaches right dorsally. Left valve has indistinct ventral lappet or tongue which wraps over right valve. Right valve lower than left and appears relatively longer. Shell surface evenly curved, smooth. Shell thick.

Interior of left valve has two low swellings or ridges slanted anteriorly from about the midheight of the valve toward the dorsal margin. These ridges divide the valve into three depressions: one poorly defined in posterior half of valve; one median pit, clearly defined, oval, deeper than others; and one in anterior quarter, not as deep as median depression. Anterodorsal half of left valve has thickened margin forming a shelf grooved parallel to margin. On well-preserved specimens shelf tapers posteriorly and is overhung by rim of valve. Trace of marginal groove posteroventrally. Interior of right valve has depressions like left, but no marginal structures.

The dimensions of an average carapace are $1.05 \mathrm{~mm}$ in length, 0.55 of a $\mathrm{mm}$ in height, and 0.45 of a $\mathrm{mm}$ in width. 
Types.-Holotype, USNM 162357 ; paratypes USNM 162358, YPM 23832-23836.

Discussion.-This species is assigned to the genus Cytherellina Jones and Holl, 1869, because of its thick shell, which is smooth externally but which has two low oblique ridges defining the adductor muscle scar internally. When Jones and Holl (1869, p. 216-217, pl. 14, figs. 1-6) redescribed and reillustrated the type species of Cytherellina, $C$. siliqua (Jones, 1855), they showed the oblique ridges impressed as grooves on steinkerns but did not mention the hinge or other marginal structures. Bonnema (1909, p. 72-75) discussed Cytherellina and assigned to it four Late Ordovician species from Estonia, but also did not mention the hinge. Most recently, Becker (1965, p. 384-385) has rediagnosed Cytherellina and has stated that the hinge is simple, with a ridge and groove in each valve. In contrast, $C$. crepiduloides has a ridge and groove hinge structure in the left valve only. Further study of the types and topotype material of $C$. sitiqua is necessary to resolve this discrepancy, but such a study is beyond the scope of this paper.

The hinge structure and marginal structure of $C$. crepiduloides is most similar to those illustrated by Adamczak (1967, figs. 2, 11) for Kuresaaria gotlandica Adamczak, 1967 , but $C$. crepiduloides lacks a contact groove in the anterior part of the left valve and, of course, the anterior sulci on the exterior of both valves which are characteristic of $K$. gotlandica, the type species of Kuresaaria Adamczak, 1967. The anterior position of the hinge of $C$. crepiduloides is established by its position relative to the adductor muscle scar and the axis of maximum thickness. Adamczak (1967, p. 464), in describing stop ridges in Silenis bassleri (Sohn, 1961) mentions analogous elements in Cytherelina from the Ordovician of Estonia. Bonnema (1909, p. 75, pl. 8, fig. 7) described and figured such structures in Cytherellina, but they appear to be the ends of the contact groove. In $C$. crepiduloides the posterior end of the contact groove is deepened and might be considered an analogous structure, but as the contact groove is missing in the anterior part of the left valve, there is no structure that could be considered an anterior stop ridge.

Becker (1965, p. 384) included a healdiid muscle scar in his diagnosis of $C y$ therellina. The adductor muscle scar of $C$. crepiduloides is well defined around the margins in some specimens and is oval to round in outline. The individual scars of the muscle bundles cannot be seen clearly in most individuals because of the type of preservation; it is not clear whether the pits shown in figure 8 are actually part of the scar or are adventitious.

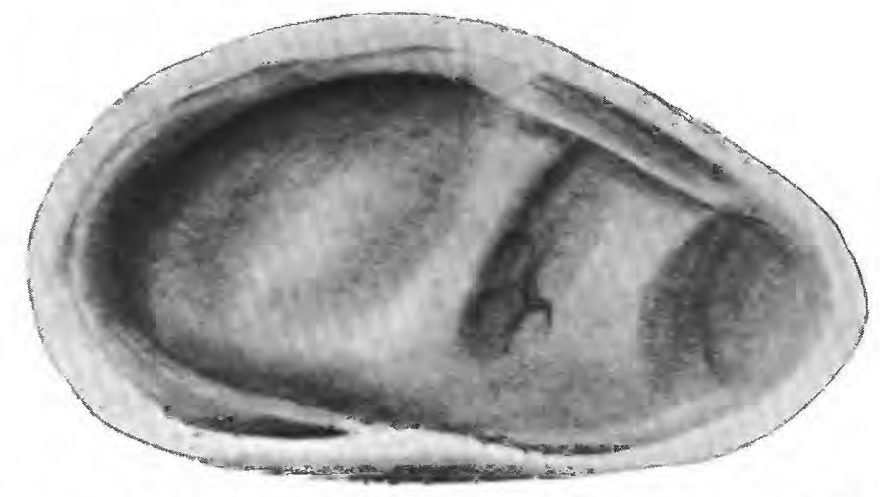

FIGURE 8.-Interior of left valve of Cytherellina crepiduloides n. sp., showing muscle pit, approximately $\times 100$. Specimen YPM 23835 from Schoharie, N.Y. Drawing by Elinor Stromberg.

Cytherellina crepiduloides is readily distinguished from the four Late Ordovician species, $C$. ulrichi, $C$. jonesii, $C$. krausei, and $C$. medemanni described by Bonnema (1909, p. 75-76), as all of these have incised hinge lines and $C$. crepiduloides does not. This feature also serves to distinguish it from the Middle Devonian C. brassicalis Becker, 1965. C. crepiduloides differs from the Middle Devonian species $C$. .? obliqua Kummerow, 1953 and $C$. dubia Kummerow, 1953 in outline, and from $C$. perlonga Kummerow, 1953 in having a thicker shell. Cytherellina crepiduloides appears to be closest to the specimens described by Jones and Holl (1869, p. 216) as $C$. siliqua from the Aymestry and upper Ludlow beds (Silurian) of England, but $C$. crepiduloides appears to have a greater dorsal overreach of the left valve.

The specific name is derived from the Latin crepidula, a small shoe, and the suffix -oides, because of the resemblance of single valves to little slippers.

Size of sample.-More than 175 carapaces and more than 25 single valves were available for study.

Occurrence.-All specimens studied in detail came from collections from Schoharie, N.Y. (YPM 5244/146, USGS 3393-SD, USGS 7283-SD). The species also occurs at Aurelius Station, N.Y. (USGS 3395-SD), west of Central Bridge, N.Y. (USGS 7198-SD), and at Shutter Corners, N.Y. (USGS 3390-SD).

\section{Genus NUNCULINA n. gen.}

Type species.-Nunculina striatopuncta $\mathrm{n}$. $\mathrm{sp}$.

Species included.-Only the type species.

Diagnosis.-Lateral outline subelliptical, dorsum curved; left valve overlaps right around free margins and overreaches right along posterodorsal hinge. Both valves have vertical median sulcus that extends from near dorsum to about midheight of valves. Anterior and posterior ends of both valves slightly flattened. Hinge 
simple. Internally, both valves have a low ridge corresponding to the median sulcus. Free margin of left valve with shallow groove into which the free margin of right valve fits.

Discussion.-This genus superficially resembles Sulcocavellina Egorov, 1950, or Sulcella Coryell and Sample, 1932. However, considering the widest end of the shell as posterior, the overlap in Nunculina is left over right, rather than right over left as in the two cavellinid genera. The hinge is short and straight, and neither thin sections nor free valves show any indication of tongue and groove structure. Dimorphism has not been observed in this genus; however, because of the weak hingement, the right valve is commonly driven into the left valve in complete carapaces, and it is difficult to be sure that the observed width of the posterior part of the shell actually represents the true width.

The generic name is a diminutive of the Latin Nunculus, a kind of nut cake.

\section{Nunculina striatopuncta n. sp.}

Plate 6, figures 8-13

Description.-Lateral outline elliptical; dorsal outline subfusiform, bluntly acuminate at anterior and posterior ends, constricted medially. Left valve larger than right, overlapping it around free margins and overreaching it along hinge. Dorsal margin evenly rounded; anterior margin sharply rounded; ventral margin slightly rounded to nearly straight; posterior margin rounded. Axis of maximum height about at midpoint; axis of maximum length passes through or slightly below midpoint; axis of maximum width in posterior third of carapace. Median sulcus extends from near dorsal margin to slightly below midpoint of both valves, passes through midpoint or may be slightly anterior to it, not clearly delimited. Hinge short, straight, posterodorsal in position. Shell surface ornamented by very fine reticulation, which appears to form lines parallel to the ventral margin and to extend into sulcus.

Interior of both valves has broad, low ridge corresponding to external median sulcus. Left valve has indistinct groove, strongest anterodorsally, around free margins into which edge of right valve fits. Left valve also has ventral lappet which overlaps right valve. Hinge without grooves or pits on either valve.

A representative specimen measures 0.8 of a $\mathrm{mm}$ in length, 0.45 of a $\mathrm{mm}$ in height, and 0.35 of a $\mathrm{mm}$ in width.

Types.-Holotype, YPM 23830; paratypes, YPM 23829, YPM 23831, YPM 23831a, USNM 162349162352.

Discussion.-The hinge of this species has been studied both from single valves and by means of thin

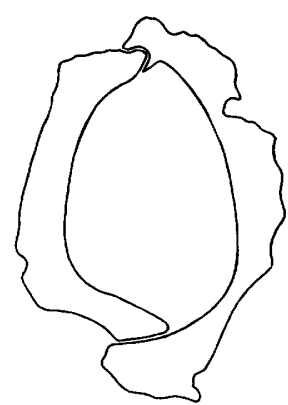

$A$

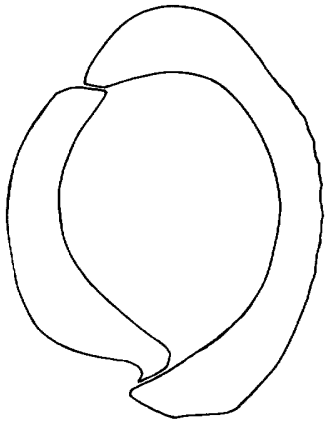

$B$
FIgURE 9.-Transverse sections of Nunculina striatopuncta $\mathbf{n}$. sp. from Schoharie, N.Y., showing contact relationship of valves. $A$, section through anterior part of shell showing anterodorsal groove in left valve into which edge of right valve fits. Exterior of carapace badly corroded. Paratype, YPM 23831a, YPM colln. 5244/146. $B$, section through posterior part of shell showing simple hinge. Paratype, USNM 162352, USGS colln. 7283-SD. Approximately $\times 90$.

sections and appears to be simple. The edges of single valves are subject to abrasion, and fine details of structure may be lost. However, thin sections prepared from apparently uncrushed carapaces also show the two valves meeting with no interlocking structures (fig. 9).

Illustrations of Sulcella volgograda Shishkinskaya (1964, p. 119-120, pl. IV, figs. 1-9) somewhat resemble this species, but as indicated under the generic discussion, the overlap is not the same.

Although a large number of specimens were available for study, all are nearly the same size, and it is possible that only adults are present in the collections, although a few smaller specimens may represent instar A-1.

The species is characterized by the peculiar fine chainlike reticulation, on which the specific name is based.

Size of sample.-More than 400 carapaces and more than 50 single valves were available for study.

Occurrence.-This species has been found at Schoharie, N.Y. (YPM 5244/146, USGS 3393-SD, USGS 7283-SD), and at Jerusalem Hill, N.Y. (YPM 2594).

\section{REFERENCES CITED}

Abushik, T. F., 1968, in Nikiforova, O. I., and Pridtechenskii, N. N., A guide to the geological excursion on Silurian and Lower Devonian deposits of Podolia (Middle Dnestr River) ; Third International Symposium on Silurian-Devonian Boundary and Lower and Middle Devonian Stratigraphy: Leningrad, Vses. Nauchno-Issled. Geol. Inst. (VSEGEI), pls. 1-37.

Adamczak, Franciszek, 1961, On the genus Poloniella Gürich (Ostracoda) : Acta Palaeont. Polonica, v. 6, no. 3, p. 283-320, pls. 1-6. 
-1966, On Kloedenellids and Cytherellids (Ostracoda, Platycopa) from the Silurian of Gotland: Stockholm Univ. Acta ; Stockholm Contr. Geology, v. 15, no. 2, p. 7-21, 5 pls.

1967, Morphology of two Silurian metacope astracodes from Gotland : Geol. Fören. Stockholm Förh., v. 88, pt. 4, no. 527, p. 462-475.

1968, Palaeocopa and Platycopa (Ostracoda) from Middle Devonian rocks in the Holy Cross Mountains, Poland: Stockholm Univ. Acta, Stockholm Contr. Geology, v. 17, 109 p., 46 pls.

Barrett, S. T., 1878, The coralline or Niagara limestone of the Appalachian system as represented at Nearpass Cliff, Montague, N.J.: Am. Jour. Sci., ser. 3, v. 15, p. 370-372.

Bassler, R. S., 1915, Bibliographic index of American Ordovician and Silurian fossils: U.S. Natl. Mus. Bull. 92, 2 v., 1521 p.

Bassler, R. S., and Kellett, Betty, 1934, Bibliographic index of Paleozoic Ostracoda: Geol. Soc. America Spec. Paper 1, $500 \mathrm{p}$.

Becker, Gerhard, 1965, Podocopida (Ostracoda) aus dem Mitteldevon der Sötenischer Mulde (N-Eifel): Senckenbergiana Lethaea, จ. 46 , no. $4 / 6$, p. $367-441$, pls, $28-35$.

Berdan, J. M., 1963, Eccentricosta, a new Upper Silurian brachiopod genus: Jour. Paleontology, v. 37, no. 1, p. 254-256.

1964, The Helderberg Group and the position of the Silurian-Devonian boundary in North America: U.S. Geol. Survey Bull. 1180-B, 19 p.

Berry, W. B. N., and Boucot, A. J., 1970, Correlation of North American Silurian rocks: Geol. Soc. America Spec. Paper $102,289 \mathrm{p}$.

Bonnema, J. H., 1909, Beitrage zur Kenntnis der Ostrakoden der Kuckersschen Schicht (C2) : Groningen Univ. Min. Geol., Inst. Mitt., v. 2, no. 1, 84 p., 8 pls.

1914, Contribution to the knowledge of the genus Kloedenella Ulrich and Bassler: Koninkl. Nederlandse Akad. Wetensch. Proc., v. 16, p. 1105-1109.

Boucot, A. J., 1959, A new family and genus of Silurian orthotetacid brachiopods : Jour. Paleontology, v. 33, no. 1, p. 25-28, pl. 3.

1961, Stratigraphy of the Moose River synclinorium, Maine: U.S. Geol. Survey Bull. 1111-E, 188 p.

Bowen, Z. P., 1967, Brachiopoda of the Keyser Limestone (Silurian-Devonian) of Maryland and adjacent areas: Geol. Soc. America Mem. 102, 103 p., 8 pls.

Clarke, J. M., 1909, Early Devonic history of New York and eastern North America: New York State Mus. Mem. 9, pt. $2,250 \mathrm{p}$.

Clarke, J. M., and Luther, D. D., 1905, Geologic map of the Tully quadrangle [N.Y.] : New York State Mus. Bull. 82, p. 34-70.

Copeland, M. J., 1962, Canadian fossil Ostracoda, Conchostraca, Eurypterida and Phyllocarida: Canada Geol. Survey Bull. 91, 57 p., 12 pls.

Drot, Jeannine, and Westbroek, Peter, 1966, Iberirhynchia santaluciensis, nouveau Rhynchonellacea du Devonien du Leon (Espagne) : Leidse Geol. Meded., v. 38, p. 165-172, 1 pl.

Fisher, D. W., 1960, Correlation of the Silurian rocks in New York State: New York State Mus. and Sci. Service Geol. Survey Map and Chart Ser., no. 1.

Flower, R. H., 1947, Cayugoceras, an Upper Silurian cephalopod : Am. Midland Naturalist, v. 37, no. 1, p. 250-255, 1 pl.

1948, Brevicones from the New York Silurian: Bulls. Am. Paleontology, v. 32, no. 129, p. 3-11, 2 pls.

Foerste, A. F., 1909, Silurian fossils from the Kokomo, West Union and Alger horizons of Indiana, Ohio, and Kentucky: Cincinnati Soc. Nat. History, Jour., v. 21, no. 1, p. 30-33, 1 pl.
Goldring, Winifred, 1935, Geology of the Berne quadrangle, with a chapter on glacial geology by John H. Cook: New York State Mus. Bull. 303, 238 p., 50 pls.

Grabau, A. W., 1900, Siluro-Devonic contact in Erie County, N.Y.: Geol. Soc. America Bull., v. 11, p. 347-376, 2 pls.

-1901, Guide to the geology and paleontology of Niagara Falls and vicinity: New York State Mus Bull. 45, 284 p. (also in Buffalo Soc. Nat. Sci. Bull. 7, 284 p., 1901.)

1903, Stratigraphy of Becraft Mountain, Columbia County, N. Y. : New York State Mus. Bull. 69, p. 1030-1079. 1906, Guide to the geology and paleontology of the Schoharie Valley in eastern New York: New York State Mus. Bull. 92, p. $77-386$.

Grabau, A. W., and Sherzer, W. H., 1910, The Monroe Formation of southern Michigan and adjoining regions: Michigan Geol. Survey, Geol. ser. 1, Pub. 2, 248 p., 32 pls.

Grabau, A. W., and Shimer, H.W., 1909, North American index fossils; Invertebrates, v. 1: New York, $853 \mathrm{p}$.

1910, North American index fossils; Invertebrates, v. 2 : New York, 909 p.

Guber, A. L., and Jaanusson, Valdar, 1964, Ordovician ostracodes with posterior domiciliar dimorphism: Uppsala Univ. Geol. Inst. Bull., v. 42, no. 53, p. 1-43.

Gürich, Georg, 1896, Das Palaeozoicum im Polnischen Mittelgebirge : Russ. Imperatorskogo c.-Peterburgskogo Mineralogicheskogo Obshchestva, Zapiski, 2nd ser., v. 32, 539 p.

Hall, James, 1852, Descriptions of the organic remains of the lower middle division of the New York system: Albany, N.Y., Palaeontology of New York, v. 2, 362 p., 84 pls.

- 1859, Descriptions and figures of the organic remains of the Lower Helderberg group and the Oriskany sandstone: New York Geol. Survey, Palaeontology, v. 3, pt. 1, 532 p.

Hall, James, and Clarke, J. M., 1892, An introduction to the study of the genera of Palaeozoic Brachiopoda: New York Geol. Survey, Palaeontology, v. 8, pt. 1, 367 p., 20 pls.

1894, An introduction to the study of the genera of Palaeozoic Brachiopoda: New York Geol. Survey, Palaeontology, v. 8, pt. 2, 394 p., 84 pls [1895].

Harper, J. D., 1968, Late Silurian stratigraphy of New York and Pennsylvania; the Rondout Formation and its correlatives [abs.] : Geol. Soc. America, Northeastern Sect., 3d Ann. Mtg. Program, p. 32-33.

Hartnagel, C. A., 1903, Preliminary observations on the Cobleskill ("Coralline") limestone of New York : New York State Mus. Bull. 69, p. 1109-1175, 3 pls.

Havlíček, Vladimír, 1961, Rhynchonelloidea des böhmischen älteren Paleozoikums (Brachiopoda): Czechoslovak Republic, Ustřední ústav geologicky Rozpravy, v. 27, 211 p., 27 pls.

1965, Superfamily Orthotetacea (Brachiopoda) in the Bohemian and Moravian Paleozoic: Czechoslovak Republic, Ústřední ústav geologicky Vestnik, v. 40, no. 4, p. 291-294, 2 pls.

1967, Brachiopoda of the suborder Strophomenidina in Czechoslovakia: Czechoslovak Republic, Ústřední ústav geologicky Rozpravy, v. 33, 235 p., 52 pls.

Henningsmoen, Gunnar, 1965, On certain features of Palaeocope ostracodes : Geol. Foren. Stockholm Förh., v. 86, p. 329-394.

Hoar, F. G., and Bowen, Z. P., 1967, Brachiopoda and stratigraphy of the Rondout Formation in the Rosendale quadrange, southeastern New York: Jour Paleontology, v. 41, no. 1 , p. $1-36,3$ pls. 
Hopkins, T. C., 1914, The geology of the Syracuse quadrangle: New York State Mus. Bull. 171, 80 p.

Hoskins, D. M., 1961, Stratigraphy and paleontology of the Bloomsburg Formation of Pennsylvania and adjacent states: Pennsylvania Geol. Survey, 4th Ser., Bull. G-36, $124 \mathrm{p}$.

Howell, B. F., 1947, Spiriferid brachiopods new to the Silurian Cobleskill formation of New York: Wagner Free Inst. Sci. Bull., v. 22, no. 1, 10 p., 3 pls.

Hyman, L. H., 1955, The invertebrates; Echinodermata, the coelomate Bilateria: New York, McGraw-Hill, $763 \mathrm{p}$.

Jones, T. R., 1858a, Notes on the Palaeozoic bivalved Entomostraca; No. 4, Some North American species: Annals and Mag. Nat. History, ser. 3, v. 1, no. 4, p. 241-255, pls. 9, 10 (part).

$1858 \mathrm{~b}$, Notes on the Beyrichiae and Leperditiae of Pennsylvania, in Rogers, H. D., The geology of Pennsylvania, a government survey : Philadelphia, v. 1, 586 p., v. 2, 1046 p.

1890, On some Palaeozoic Ostracoda from North America, Wales, and Ireland: Geol. Soc. London Quart. Jour., v. 46, p. 1-31, 4 pls.

Jones, T. R., and Holl, H. B., 1869, Notes on the Palaeozoic bivalved Entomostraca; No. 9, Some Silurian species: Annals and Mag. Nat. History, ser. 4, v. 3, no. 15, p. 211-227, pls. 14, 15.

Kesling, R. V., 1969, Copulatory adaptations in ostracodes, pt. 3, Adaptations in some extinct ostracodes: Michigan Univ. Mus. Paleontology Contr., v. 22, no. 21, p. 273-312.

Kesling, R. V. and Wagner, P. L., 1956, Silurian ostracodes collected by Dr. Carl Ludwig Rominger from glacial deposits in Germany : Michigan Univ. Mus. Paleontology Contr., v. 13, no. 2, p. 33-79, 8 pls.

Kozlowski, Roman, 1929, Brachiopodes Gothlandiens de la Podolie Polonaise: Palaeontologia Polonica, v. 1, 254 p., 12 pls.

1946, Howellella, a new name for Crispella Kozlowski, 1929: Jour. Paleontology, v. 20, no. 3, p. 295.

Kummerow, Egmont, 1931, Orientation of the carapaces of Paleozoic Ostracoda : Jour. Paleontology, v. 5, no. 2, p. 155159.

Lamont, Archie, 1935, The Drummock group, Girvan; a stratigraphical revision, with descriptions of fossils from the lower part of the group: Geol. Soc. Glasgow Trans., v. 19, pt. 2, p. 288-332.

Lundin, R. F., 1965, Ostracodes of the Henryhouse Formation (Silurian) in Oklahoma : Oklahoma Geol. Survey Bull. 108, 104 p., 18 pls.

Luther, D. D., 1910, Geology of the Auburn-Genoa quadrangles: New York State Mus. Bull. 137, 36 p.

Martinsson, Anders, 1956, Ontogeny and development of dimorphism in some Silurian ostracodes: Uppsala Univ. Geol. Inst. Bull., v. 37, no. 14, p. 1-42, 5 pls.

1962, Ostracodes of the family Beyrichiidae from the Silurian of Gotland: Uppsala Univ. Geol. Inst. Bull., v. 41, $369 \mathrm{p}$.

1963, Kloedenia and related ostracode genera in the Silurian and Devonian of the Baltic area and Britain: Uppsala Univ. Geol. Inst. Bull., v. 42, p. 1-63.

1967, The succession and correlation of ostracode faunas in the Silurian of Gotland: Geol. Fören. Stockholm Förh., v. 89 , p. $350-386$.

Merrill, F. J. H., 1902, State Museum, Paleontology : New York State Univ., Secretary's Rept., Regents Bull. 59, p. r41-r42.
Miller, S. A., 1877, The American Paleozoic fossils; a catalogue of the genera and species ***: Cincinnati, Ohio, $253 \mathrm{p}$.

Moore, R. C., ed., 1961, Treatise on invertebrate paleontologyPart Q, Arthropoda 3: New York and Lawrence, Kans., Geol. Soc. America and Univ. Kansas Press, 442 p.

1965, Treatise on invertebrate paleontology-Part $H$, Brachiopoda 1 and 2 : New York and Lawrence, Kans., Geol. Soc. America and Univ. Kansas Press, $927 \mathrm{p}$.

Polenova, E. N., 1960, Devonskie ostrakod'ii kuznetskogo basseina i minusinskoi kotlovin'i : Vses. Neft. Nauchno-Issled. Geol.-Razved. Inst. (VNIGRI) Trudy, no. 152, 139 p., 13 pls.

Prouty, W. F., and Swartz, C. K., 1923, Brachiopoda, in Swartz, C. K., and others, Systematic paleontology-Silurian : Maryland Geol. Survey, Silurian, p. 412-467.

Reeside, J. B., 1917, The Helderberg limestone of central Pennsylvania: U.S. Geol. Survey Prof. Paper 108-K, p. 185-225.

Rickard, L. V., 1962, Late Cayugan (Upper Silurian) and Helderbergian (Lower Devonian) stratigraphy in New York: New York State Mus. and Sci. Service Bull. 386, 157 p. 1969, Stratigraphy of the Upper Silurian Salina Group, New York, Pennsylvania, Ohio, Ontario: New York State Mus. and Sci. Service Map and Chart Ser. no. 12, 57 p. 14 pls.

Rickard, L. V., and Zenger, D. H., 1964, Stratigraphy and paleontology of the Richfield Springs and Cooperstown quadrangles: New York State Mus. and Sci. Service Bull. 396. $101 \mathrm{p}$.

Rubel, M. P. and Modzalerskaya, T. L., 1967, Nov'ie siluriiskie brachiopod'i semeistva Athyrididae (New Silurian brachiopods of the Family Athyrididae) : Akad. Nauk Eston. SSR Izv., Ser. Khimiya-Geologiya, v. 16, no. 3, p. 238-247.

Sartenaer, Paul, 1970, Nouveau genres rhynchonellides (brachopodes) du Paleozoique : Belgique Inst. Royal Sci. Nat. Bull. 46, $32 \mathrm{p}$.

Schuchert, Charles, 1897, A synopsis of American fossil Brachiopoda, including bibliography and synonymy: U.S. Geol. Survey Bull. 87, $464 \mathrm{p}$.

1903a, On the lower Devonic and Ontaric formations of Maryland : U.S. Natl. Mus. Proc., v. 26, p. 413-424.

$1903 \mathrm{~b}$, On the Manlius formation of New York: Am. Geologist, v. 31, p. 160-178.

Schuchert, Charles, and Maynard, T. P., 1913, Systematic paleontology of the Lower Devonian deposits of Maryland; Brachiopoda : Maryland Geol. Survey, Lower Devonian, p. $290-449$.

Shimer, H. W., and Shrock, R. R., 1944, Index fossils of North America : New York, John Wiley and Sons, $837 \mathrm{p}$.

Shishkinskaya, A. F., 1964, Ostrakod'i Famenskogo yarusa verkhnego devona Volgogradskoi oblasti : Akad. Nauk SSSR, Inst. Geol. i Razrabotki Goruchikh Iskopaem'ikh, Biostratigrafiya neftigazonosn'ikh oblastei SSSSR, p. 105-140.

Smith, Burnett, 1935, Geology and mineral resources of the Skaneateles quadrangle: New York State Mus. Bull. 300, 120 p. 61 pls.

Swartz, C. K., and Swartz, F. M., 1941, Early Devonian and late Silurian formations of southeastern Pennsylvania: Geol. Soc. America Bull., v. 52, no. 8, p. 1129-1192.

Swartz, F. M., 1929, The Helderberg group of parts of West Virginia and Virginia: U.S. Geol. Survey Prof. Paper 158-C, p. 27-75, 4 pls.

1933, Dimorphism and orientation in ostracods of the family Kloedenellidae from the Silurian of Pennsylvania : Jour. Paleontology, v. 7, no. 3, p. 231-260, 3 pls. 
1939, The Keyser Limestone and Helderberg Group in The Devonian of Pennsylvania : Pennsylvania Geol. Survey, 4th ser., Bull. G-19, p. 29-91, 383-385, pls. 1, 2.

1949, Muscle marks, hinge and overlap features, and classification of some Leperditiidae: Jour. Paleontology, v. 23, no. 3, p. 306-327, 3 pls.

Swartz, F. M., and Whitmore, F. C., Jr., 1956, Ostracoda of the Silurian Decker and Manlius limestones in New Jersey and eastern New York: Jour. Paleontology, v. 30, no. 5, p. 10291091,8 pls.

Ulrich, E. O., 1894, The Lower Silurian Ostracoda of Minnesota : Minnesota Geol. Survey Final Rept., v. 3, pt. 2, p. 629693,5 pls.

Ulrich, E. O., and Bassler, R. S., 1908, New American Paleozoic Ostracoda; preliminary revision of the Beyrichiidae, with descriptions of new genera: U.S. Natl. Mus. Proc., v. 35, p. 277-340, 8 pls.

1913, Systematic paleontology of the Lower Devonian deposits of Maryland; Ostracoda: Maryland Geol. Survey, Lower Devonian, p. 513-542.

1923, Systematic paleontology of Silurian deposits ; Ostracoda : Maryland Geol. Survey, Silurian, p. 500-704, 30 pls.

Vanuxem, Lardner, 1842, Geology of New York. Part III, comprising the survey of the third geological district, Albany, 306 p.
Van Veen, J. E., 1921, De identiteit de Ostracodengeslachten Poloniëlla en Kloedenella : Gewone Vergadering Wis- en Natuurkundige Afdeeling 18 Dec. 1920, Verslag, v. 29, p. $888-892$.

1922, The identity of the genera Poloniella and Kloedenella : Koninkl. Nederlandse Akad. Wetensch. Proc., v. 23, no. 7 , p. 993-996.

Warthin, A. S., Jr., 1937, Beyrichiacea in Type invertebrate fossils of North America (Devonian) : Wagner Free Inst. Sci. Unit 9-A, 106 cards.

Weller, Stuart, 1900 , A preliminary report on the stratigraphic paleontology of Wallpack Ridge, in Sussex County, New Jersey : New Jersey Geol. Survey Ann. Rept. 1899 : p. 1-46. 1903, The Paleozoic faunas: New Jersey Geol. Survey Paleontology [Rept.], v. 3, 462 p.

Weyant, Marcel, 1968, Ostracodes du genre Poloniella Gürich au Dévonien Moyen de lêle Ellesmere (Archipel Arctique Canadien) : Rev. Micropaléontologie, v. 11, no. 2, p. 99-110.

Williams, M. Y., 1919, The Silurian geology and faunas of Ontario Peninsula and Manitoulin and adjacent islands: Canada Geol. Survey Mem. 111, 193 p.

Whitfield, R. P., 1882, Paleontology : [Wisconsin Geol. Survey], Geology of Wisconsin, v. 4, p. 161-363. 


\section{N D E X}

[Italic page numbers indicate both major references and descriptions]

A

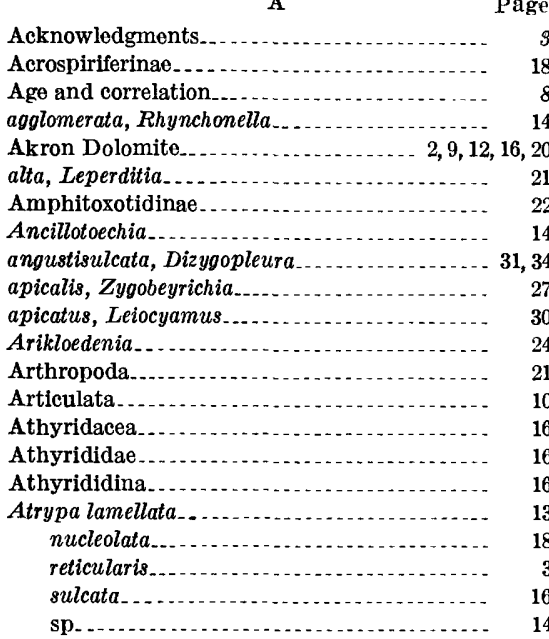

B

Bairdiocyprididae.....................

barretti, Beyrichia . . . . . . . . . . . . . . . 24, 27

Kloedenia.......................... 27

Kloedeniopsis ............ 7,9,27; pl. 3

Zygobeyrichia .......................... 27

bassleri, Silenis .......................... 40

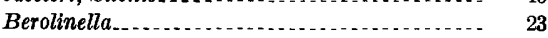

Bertie Limestone..........................

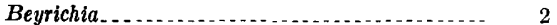

barretti.................... 24, 27

Clarkei... . . . . . . . . . . . 32, 33

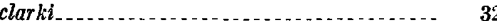

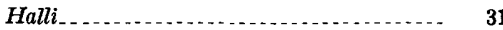

halli........... 31

Hallii................................. 31

notata

notata-ventricosa.................. 33

oculina

Beyrichlacea.......... 22

Beyrichicopina......................... 22

Beyrichildae............... 22, 23

Beyrichilnae_....................... 24, 26

Beyrichiopsidae.............................. 38

Bibliography

Bingeria

bipartita, Leptaena

Leptostrophia......... bipartita.......................... 10

bipartita, Leptostrophia.................... 10

nearpassi, Leptostrophia

Stropheodonta.................................. 10

(Leptostrophia) ...................... 10

Strophomena........... 10

biseriata, Garniella......................... 22

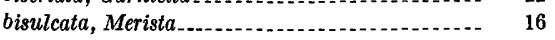

bonnemai, Bonneprimites..................... 38

Bonneprimites............................ 38

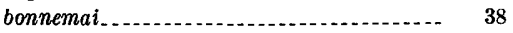

breviformis...................... 6

Brachiopoda.................................. 10

brassicalis, Cytherellina

Brayman Shale............ 1,5

breviformis, Bonneprimites...............7,9,38; pl. 6

Bullhead limestone........................ 9,20

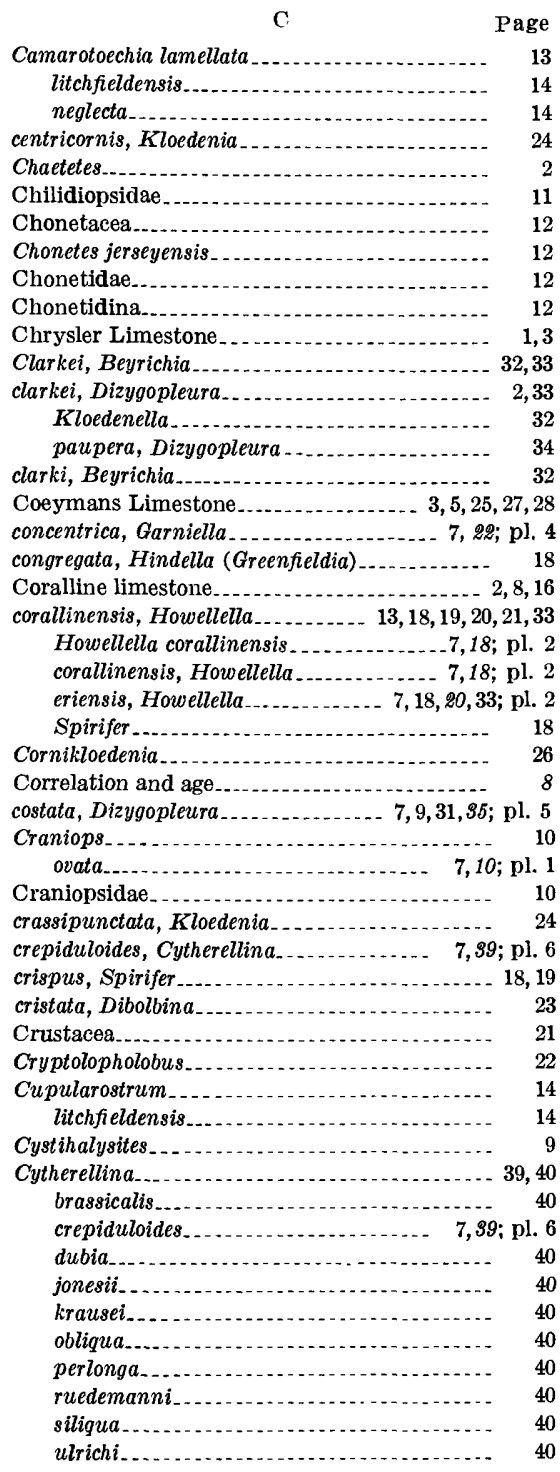

D

dalmanelliformis, Morinorhynchus........... 11

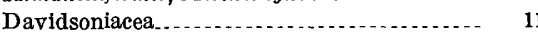
Decker Limestone..... 3, 8, 9, 12, 13, 15, 21, 27, 30, 34, 39 deckerensis, Machaeraria Rhynchonella...................... 13 Stenoschisma

Delthyrididae............................ 18 denticulata, Tikiopsis.............. 7,8,27,29; pl. 3 devonica, Poloniella....................... Dibolbina................................. 23 cristata............................... 23 producta............................... 23

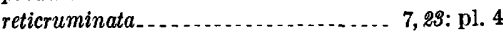
sp..................................... 9

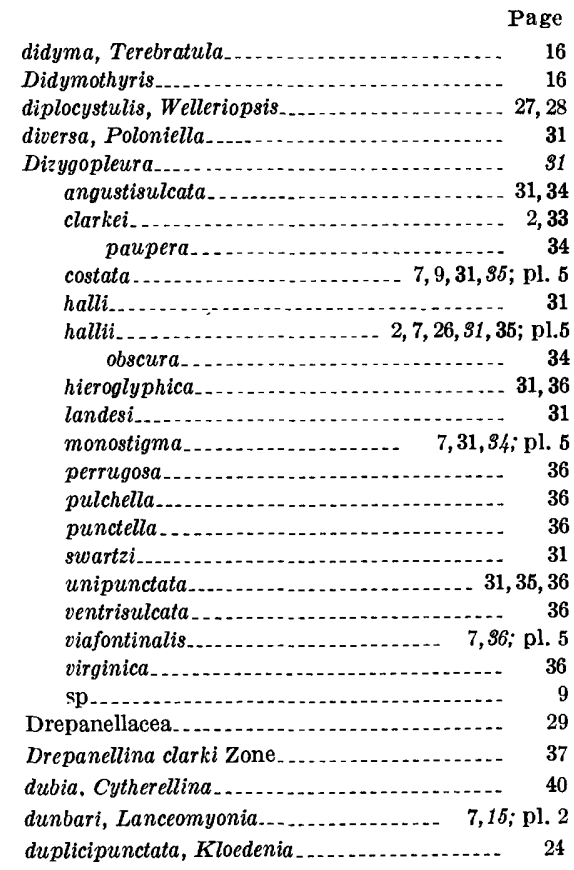

$\mathbf{E}$

Eccentricosta jerseyensis_... $\ldots \ldots \ldots \ldots, 12 ; \mathrm{pl} .1$ Zone

eriensis, Howellella Howellella corallinensis.......... 7,18,20,33; pl. 2 Spirifer................ 20

Eukloedenella.............................. 37 abrupta................ 37, 38 sinuata. umbilicata.............................. 38 weldae .......................... 7, $97 ; \mathrm{pl} 6$

F

Fardenia fimbriata, Kloedenia........................... 24 Foersteoceras formosa, Machaeraria......................... 13

Framella................................... 31

G

Garniella_............................... 9,22

biseriata concentrica............ 7,22; pl. 4 gebhardii, Mitroceras...........................

Trochoceras

gibbera scalaris, Leperditia

Glasco Member of Rondout Formation....... 8,14 gotlandica, Kuresaaria granulata, Kloedenia ....................... 25

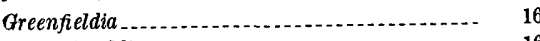
whitfieldi.................................. 16 $\begin{array}{ll}\text { (Greenfieldia) congregata, Hindella............ } & 18 \\ \text { Gypidula prognostica......................... } & 34\end{array}$ 
$\mathrm{H}$

Halli, Beyrichia

halli, Beyrichia

Dizygopleura ........................... 31

Kloedenella........................... 31

Halliella................................... 30

sp............................... 7, pl. 6

Hallii, Beyrichia ........................... 31 Poloniella........................... 31

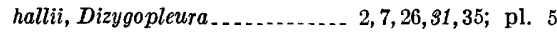
obscura, Dizygopleura ................ 34

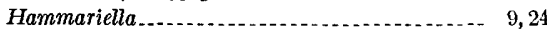
pulchrivelata............................ 24 warthini ....................... 7,24; pl. 4 Hardwood Mountain Formation.............. 36 hartnageli, Howellella vanuxemi Kloedeniopsis............. 7,24,25,26, s9; pl. 3 Healdiacea.................................. 39

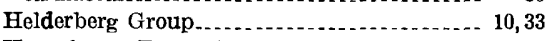

Henryhouse Formation

hieroglyphica, Dizygopleura .................. 31, 36

Hindella

Greenfieldia) congregata

Hollinacea . ..... 29

Hollinid _............................... 29; pl. 6

Hollinidae................................ 29

Howellella $\ldots . .7,18,19,20$

corallinensis_................. 13, 19,20, 21,33 corallinensis..................... 7,18; pl. 2 eriensis.................. 7,18,20,33; pl. 2 eriensis .................................... 20,21

keyserensis ............................... 2, 18, 20

modesta $\ldots \ldots \ldots \ldots$

plicata

modestus...

octocostata humilis

ancemi hartnagli

humilis, Howellella octocostata $\ldots . . . . . . . . . . . . .2$

hydraulicus, Orthothetes...................... 11

I

Iberirhynchia $\ldots \ldots \ldots \ldots \ldots$ santaluciensis inaegualis, Thlipsuropsis.............. 7, 9,98; pl. 6 Inarticulata ............................... 10 interstriata, Morinorhynchus................. 11, 12 Orthis_................................. 11 Schellwienella.......................... 11

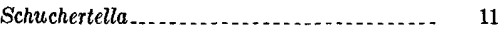
interstriatus, Morinorhynchus....... 7,11,18,33; pl. 1

Orthothetes.................. 11

Jamesville Member of Manlius Limestone..... $\quad 16$ jerseyensis, Chonetes....................... 12 Eccentricosta.................. 6, 7,12; pl. 1 Welleriopsis _............................ 27 jonesi, Leperditia......................... 2, 21, 22 jonesii, Cytherellina ........................... 40 Juviella

Kalkberg Limestone Keyser Limestone........................ 8 $9,10,12,13,15,18,20,21,27,33,34,37,39$ keyserensis, Howellella ..................... 2, 18, 20 Kirkbyella Kirkbyellid............................ 29; pl. 6 Kirkbyellidae................................ 29

Kloedenella clarkei_................................ 32 halli......................................... 31 obliqua rectangularis........................... 37

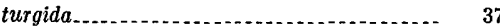
sp................................ 7, 37; pl. 6

Kloedenellacea ............................ 31 Kloedenellicopida........................ 31 Kloedenellidae ............................... 31 kloedenellides, Sulcella (Sulcella).............. 37
Page

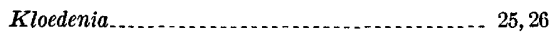

tarretti

centricornis

crassipunctata....................... 24

duplicipunctata......................... 24

fimbriata

granulata............................. 25

kokomoensis_........................ 24

montaguensis.................. 25

newbrunswickensis....................... 28

normalis............................ 25

notata

oculina

retifera

wilckensiana............................ 25

Kloedeniinae............................ 25

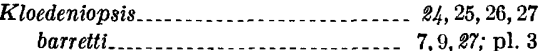
hartnageli................. 7, 24, 25, 26, 33; pl. 3 lokomoensis

kokomoensis, Kloedenia ..................... 24 Kloedeniopsis.

krausei, Cytherellina

Kuresacria gotlandica

\section{L}

lamellata, Atrypa Camarotoechia ......................... 13 Machaeraria................. 5, 6, 7,18, 14; pl. 2 Rhynchonella........................ 13 Stenoschisma

Lanceomyonia............................. 15 dunbari $\ldots$ landesi, Dizygopleura $\ldots . . . . . . . . . . . . . . . . . \quad 31$

Leiocyamidae ............................ 29

Leiocyamus_............................ 9, 29, 30 apicatus ............................ 30 punctatus....................... 7, 29,30; pl. 6 sp. A . sp. B sp......... 9

Leperditellidae.................................. 38

Leperditia ............................... 21

alta gibbera scalaris_.......................... 21 jonesi scalaris_.... $2,7,9,21$, pl, 3 Leperditiidae _.

Leptaena .................................... 10 bipartita ........................... 10, 11 rhomboidalis........................ 3,4

Leptostrophia............................... 10

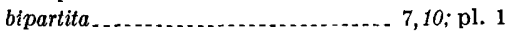
bipartita......................... 10 nearpassi

(Leptostrophia) bipartita, Stropheodonta........ 10 textilis, Stropheodonta............... 10

Leptostrophinae........................... 10

Limbinaria

muricata

Singulacea-........... 10

Lingulida_............ 10

litchfieldensis, Camarotoechia Cupularostrum .......................... 14 Microsphaeridiorhynchus_.......... 7,13,14; pl. 2 Rhynchonella Localities............................... 5

Lophoctenella .............................. 22

Lophokloedenia . .......................... 24, 25, 26

M

Machaeraria deckerensis............................. 7,19

formosa $\ldots . . . \ldots$ lamellata.................... 5, 6,7,19,14; pl. 2

Manlius Formation.......................... 8

Manlius Limestone......................... 2, 3,21,33

Marginia.

sp.................................... 88; pl. 6 Merista bisulcata nucleolata sulcata

Meristella nucleolata

Metacopina................................. 38

Microsphaeridiorhynchus..................... 14 litchfieldensis.................... 73,14; pl. 2

Migmatella martinssoni...................... 7,22,23; pl. 4 sp.

minuta, Protathyris

18 gebhardii
odesta, Howellella. plicata, Howellella............... 20

modestus, Howellella Spirifer............................. 18 plicatus, Spirifer

monostigma, Dizygopleura ............... 7,31,34; pl. 5

montaguensis, Kloedenia.............. 25

Morinorhynchus ........................... 11, 12 dalmanelliformis........................ 11

interstriata......... 11,12 interstriatus..................... 7, 11, 18, 33; pl. 1 muricata, Limbinaria

\section{$\mathrm{N}$}

nearpassi, Leptostrophia bipartita.

lecta, Camarotoechia

Rhynchonella.

New Scotland Limestone...

newbrunswickensis, Kloedenia

normalis, Kloedenia

notata, Beyrichia

Kloedenia..

notata-ventricosa, Beyrichia......................

nucleolata, Atrypa....... 18 Merista................................. 18

Meristella

Protathyris......................6, 7, 16,18; pl. 2

Whitfieldella............................. 18

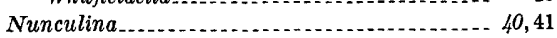
striatopuncta $\ldots . . . . . . . . . . . .40,41 ;$ pl. 6

Nynhamella musculimonstrans................ 37

o

obliqua, Cytherellina

Kloedenella

obscura, Dizygopleura hallii

octocostata humilis, Howellella............... 2

Octonaria inaequalis ....................... 38, 39 oculina, Beyrichia........................ 33

Orthis interstriata...

Orthorhynchulinae.

Orthothetes hydraulicus. interstriatus.

Ostracoda.

vata, Craniops Pholidops...

ovatus, Pholidops.

Oxbow Dolomite

$\mathrm{P}$

Palaeocopida.

Paleoecology

Parabolbina

parva, Thlipsurella

paupera, Dizygopleura clarkei.

perlonga, Cytherellina.

perrugosa, Dizygopleura.

Pholidops ovata ovatus.

Pintopsis.

plicatus, Spirifer modestus 


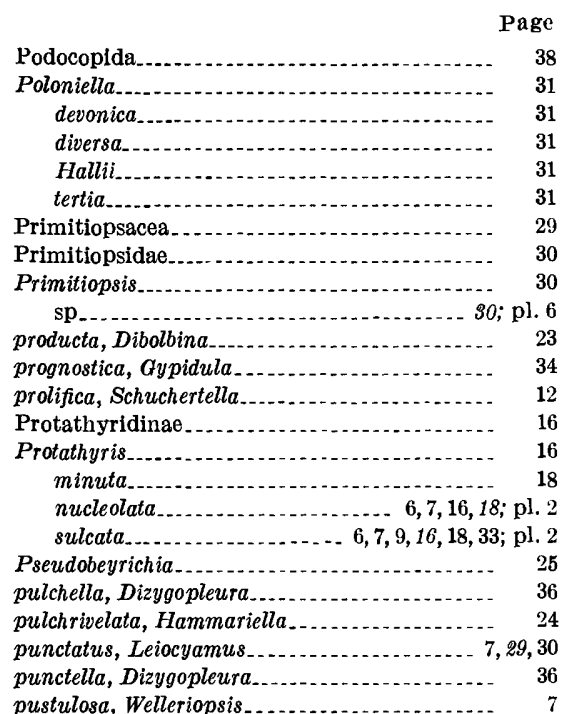

\section{R}

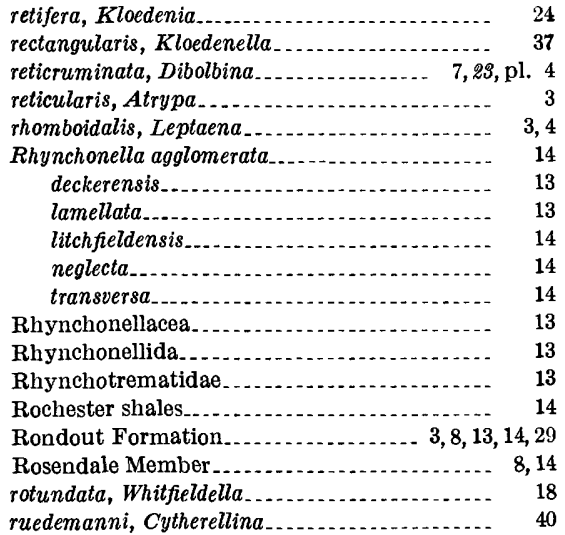

S

santaluciensis, Iberirhynchia ............... 14 scalaris, Leperditia................ 2, 7, 9, 21; pl. 3 Leperditia gibbera.

Schellwienella interstriata

Schuchertella interstriata....................... 11 prolifica.

Scipionis.

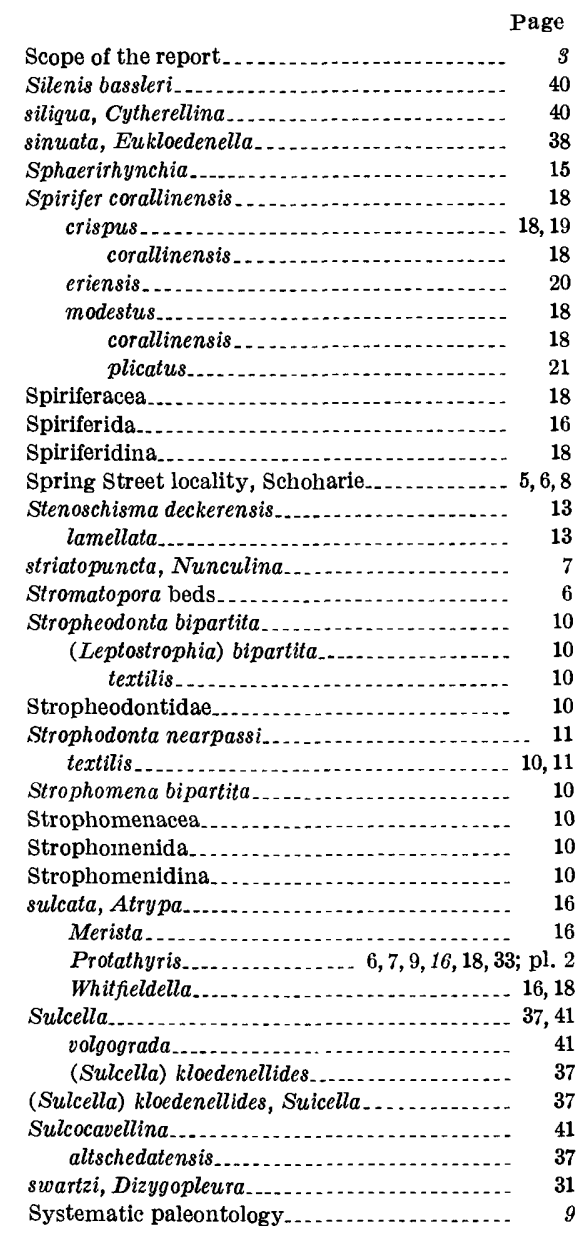

\section{$\mathrm{T}$}

Tentaculites.

2

Terebratula didyma..................... $\quad 16$

tertia, Poloniella.............................. 31

textilis, Stropheodonta (Leptostrophia)

Strophodonta............................ 10,11

Thacher Member of Manlius Limestone...... 8

Thlipsuracea.............................. 38

Thlipsurella................................ 39

ellipsoclefta............. $\quad 39$

parva ............................ 7, 39; pl. 6
Page

Thlipsuridae 38

Thlipsuropsis_........................... 38

inaequalis........................ $7,9,38 ;$ pl. 6

longisulcata..................... 38, 39

Tikiopsis ......................

denticulata...................... 7,8, 27,$29 ; \mathrm{pl}, 3$

Tonoloway Limestone .......... . 9, 13, 15, 18, 34, 36, 37

transversa, Rhynchonella................

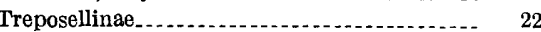

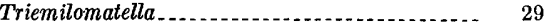

Trigonirhynchiidae....

Trochoceras gebhardii......................... 2 turbinata.............................. 2

turbinata, Trochoceras...................... 2

turgida, Kloedenella......................... 37

$\mathbf{U}$

ulrichi, Cytherelling 40

umbilicata, Eukloedenella

Uncinulidae................................. 15

unipunctata, Dizygopleura.................. 31, 35, 36

vanuxemi hartnageli, Howellella............... 2 ventrisulcata, Dizygopleura................... 36 viafontinalis, Dizygopleura.............. 7, 86 ; pl. 5 virginica, Dizygopleura........................ 36 volgograda, Sulcella.

warthini, Hammariella................... 7, 24: pl. 4 Waterlime Group of Manlius................ 16, 33 weldae, Eukloedenella .................... 7, s7; pl. 6 Welleria.

Welleriella..........

Welleriopsis..................... 25, 26, 27, 28, 29

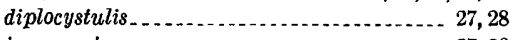
jerseyensis . . . . . . . . . pustulosa ......................... 7, 28; pl. 3 sp.................... 29; pl. 3 Whitfieldella............. 16 nucleolata............................... 18 rotundata $\quad 18$

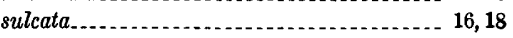
whitfieldi, Greenfieldia.................... 16 Wilbur Limestone Wilbur Member.......................... 8,9,29 wilckensiana, Kloedenia..

\section{Z}

Zygobeyrichia $24,25,26,27$

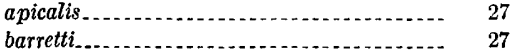
regina................................. 33 



\section{PLATES 1-6}

Contact photographs of the plates in this report are available, at cost, from U.S. Geological Survey Library, Federal Center, Denver, Colorado 80225. 


\section{PLATE 1}

[Figs. 6, 7, $\times 5$; all others $\times 3$ ]

Figures 1-5. Morinorhynchus? interstriatus (Hall) (p. 11).

1. Brachial view of crushed fragmentary shell, YPM 23789; Forge Hollow, N.Y., YPM collection 5244/90B.

2. Pedicle valve of an average specimen, YPM 23790; Aurelius Station, N.Y., YPM collection 5244/14.

3. Interior of brachial valve showing brachiophores, YPM 23791; Aurelius Station, N.Y., YPM collection $5244 / 14$.

4. Interior of larger brachial valve showing cardinal process, brachiophores broken, YPM 23792; Aurelius Station, N.Y., YPM collection 5244/14.

5. Interior of beak area of broken pedicle valve, showing pseudodeltidium and interarea, YPM 23793; Forge Hollow, N.Y., YPM collection 5244/90B.

6, 7. Craniops ovata (Hall) (p. 10).

6. Exterior and interior of brachial valve, USNM 162277, 162278; Schoharie, N.Y., USGS collection 3393-SD.

7. Interior of brachial valve, USNM 162278; Schoharie, N.Y., USGS collection 3393-SD.

8-11. Eccentricosta jerseyensis (Weller) (p. 12).

8. Exterior of pedicle valve showing curving irregular costae, YPM 16070; Jerusalem Hill, N.Y., YPM collection 2594.

9. Interior of brachial valve showing cardinalia, YPM 16069; Jerusalem Hill, N.Y., YPM collection 2594.

10. Interior of pedicle valve showing callus platform, USNM 162279; Shutter Corners, N.Y., collection USGS $3390-\mathrm{SD}$.

11. Exterior of pedicle valve showing spines, YPM 23794; Jerusalem Hill, N.Y., YPM collection 2594.

12-14. Leptostrophia bipartita (Hall) (p. 10).

12. Interior of brachial valve showing cardinalia, YPM 23795; near Glenerie, N.Y., YPM collection 5244/3.14S.

13. Impression of exterior and part of interior of brachial valve showing ornamentation, USNM 162280; Shutter Corners, N.Y., USGS collection 3390-SD.

14. Squeeze of calcined specimen showing interior of pedicle valve, YPM 23796; Shutter Corners, N.Y., YPM collection 5244/150. 

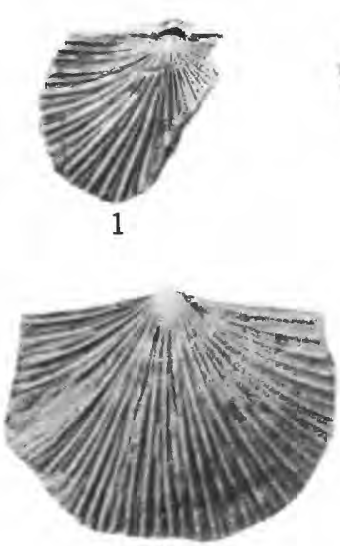

2

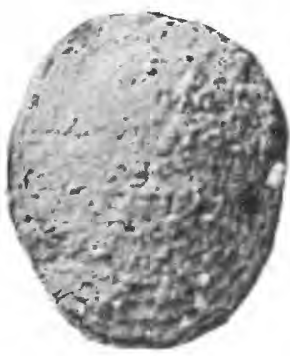

6

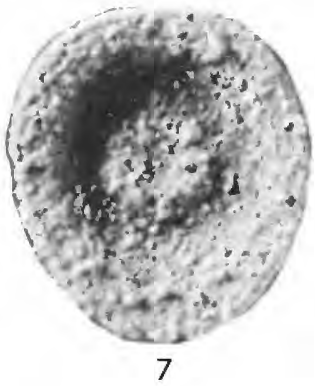

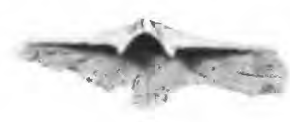

5

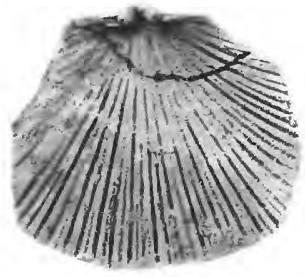

4
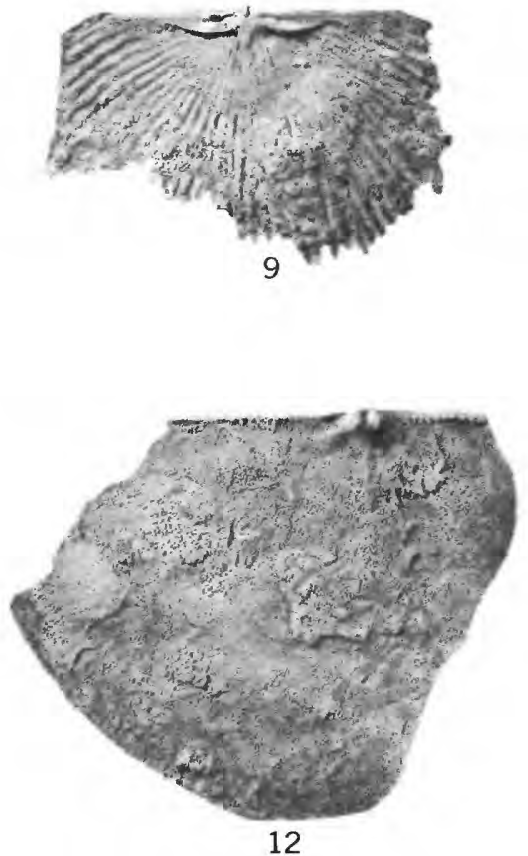

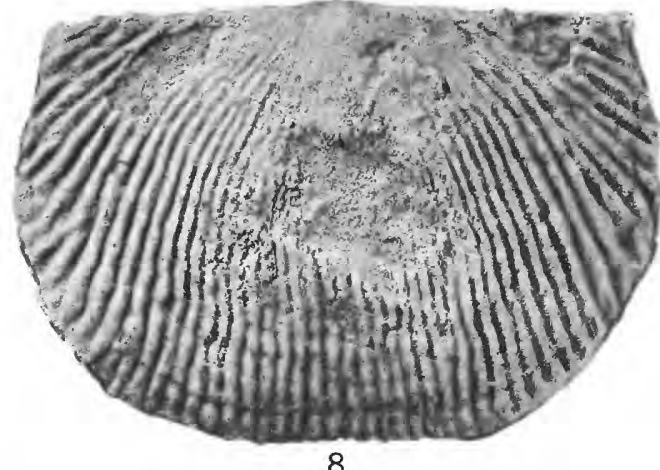

8
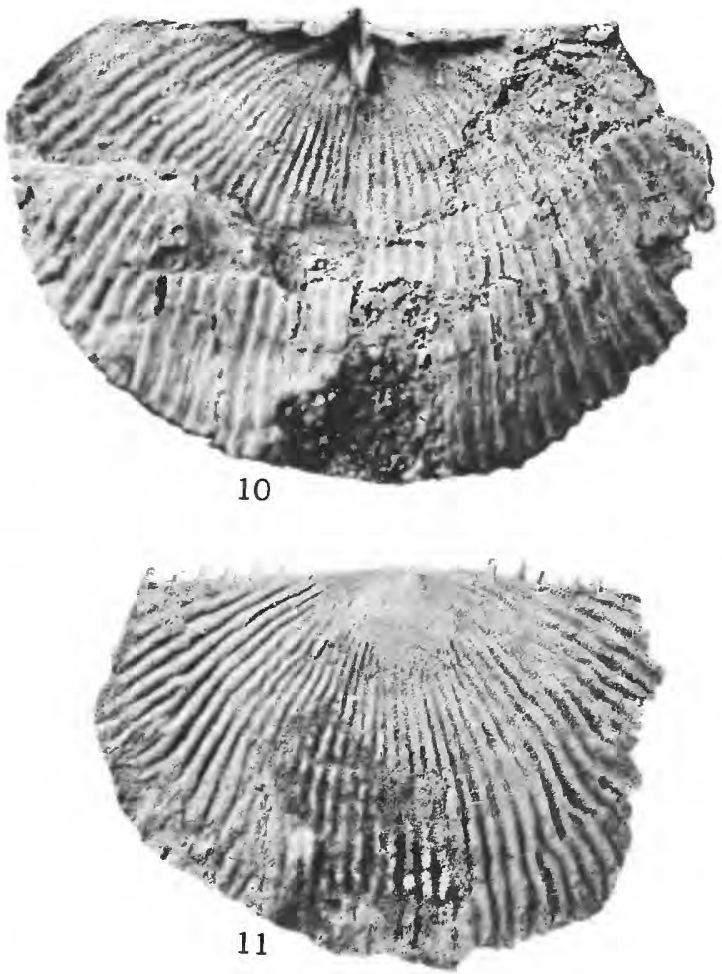
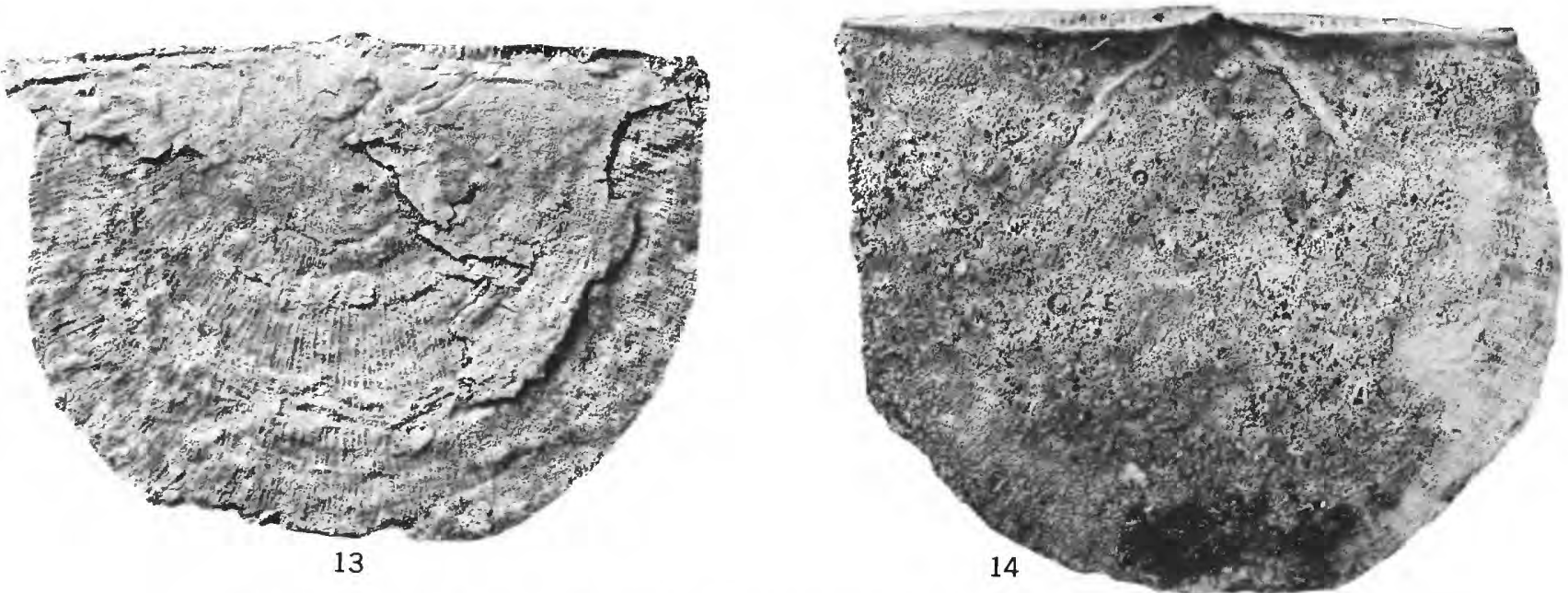

MORINORHYNCHUS?, CRANIOPS, ECCENTRICOSTA, AND LEPTOSTROPHIA 


\section{PLATE 2}

[All figures $\times 3$ ]

Figures 1-8. Lanceomyonia? dunbari n. sp. (p. 15).

1-4. Pedicle, lateral, anterior, and brachial views of small specimen, YPM 23797; Shutter Corners, N.Y., YPM collection 5244/150.

5-8. Pedicle, brachial, anterior, and lateral views of holotype, YPM 23798; Aurelius Station, N.Y., YPM collection 5244/14.

9-16. Machaeraria? lamellata (Hall) (p. 13).

9-11. Pedicle, anterior, and lateral views of an immature specimen, USNM 162281; Schoharie, N.Y., USGS collection 3393-SD.

12-15. Pedicle, brachial, anterior, and lateral views of a larger specimen, USNM 162282, Schoharie, N.Y., USGS collection 3393-SD.

16. Interior of brachial valve showing divided hinge plate, YPM 23799; Schoharie, N.Y., YPM collection 5244/ 146.

17-29. Microsphaeridiorhynchus litchfieldensis (Schuchert) (p. 14).

17. Interior of brachial valve showing hinge plate and median septum, YPM 23800; Aurelius Station, N.Y., YPM collection 5244/14.

18-21. Pedicle, brachial, lateral, and anterior views of an immature specimen, YPM 23801; Schoharie, N.Y., YPM collection 5244/146.

22-25. Pedicle, brachial, lateral, and anterior views of a large specimen, YPM 23802; Schoharie, N.Y., YPM collection 5244/146.

26-29. Pedicle, brachial, lateral, and anterior views of a smaller specimen, YPM 23803; Schoharie, N.Y., YPM collection 5244/146.

30-35. Protathyris sulcata (Vanuxem) (p. 16).

30-33. Pedicle, brachial, posterior, and lateral views of an average specimen, YPM 23804; Aurelius Station, N.Y., YPM collection 5244/1.56.

34. Lateral view of weathered specimen showing spire, YPM 23805. Specimen sectioned after photography. Aurelius Station, N.Y., YPM collection 5244/1.56.

35. Interior of posterior end of silicified shell showing dental lamellae and hinge plate, USNM 162283; Aurelius Station, N.Y., USGS collection 3395-SD.

36-40. Protathyris nucleolata (Hall) (p. 18).

36-39. Pedicle, lateral, anterior, and brachial views of an average specimen, YPM 23806; Schoharie, N.Y., YPM collection 5244/146.

40. Pedicle view of a larger specimen, YPM 23807; Jerusalem Hill, N.Y., YPM collection 5244/108.

41-48. Howellella corallinensis eriensis (Grabau) (p. 20).

41-44. Pedicle, brachial, anterior, and lateral views of a specimen showing weak lateral costae, YPM 23808; Aurelius Station, N.Y., YPM collection 5244/1.56.

45. Interior of silicified brachial valve showing crural bases and small cardinal process, USNM 162284; Aurelius Station, N.Y., USGS collection 3395-SD.

46. Pedicle valve of specimen showing angular sulcus and growth varices, YPM 23809; Forge Hollow, N.Y., YPM collection 5244/90B.

47. Interior of pedicle valve showing flaring deltidial plates and thin median carina, YPM 23810; Aurelius Station, N.Y., YPM collection 5244/14.

48. Interior of pedicle valve with cardinal area slightly broken, showing dental lamellae and low median carina, YPM 23811; Aurelius Station, N.Y., YPM collection 5244/14.

49. Howellella corallinensis corallinensis (Grabau) (p. 18).

Pedicle valve showing lack of lateral costae, YPM 23812; Shutter Corners, N.Y., YPM collection 5244/150. 
GEOLOGICAL SURVEY
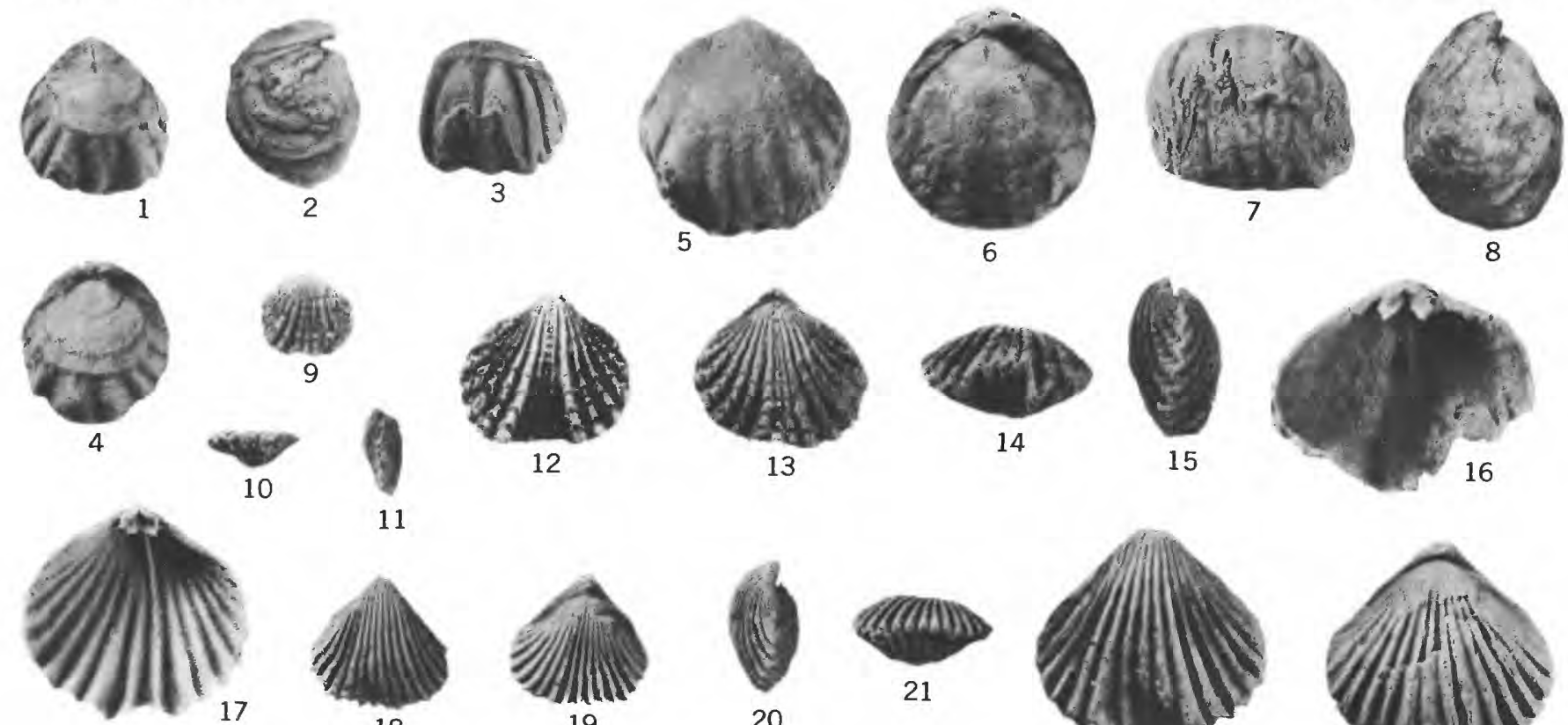

12
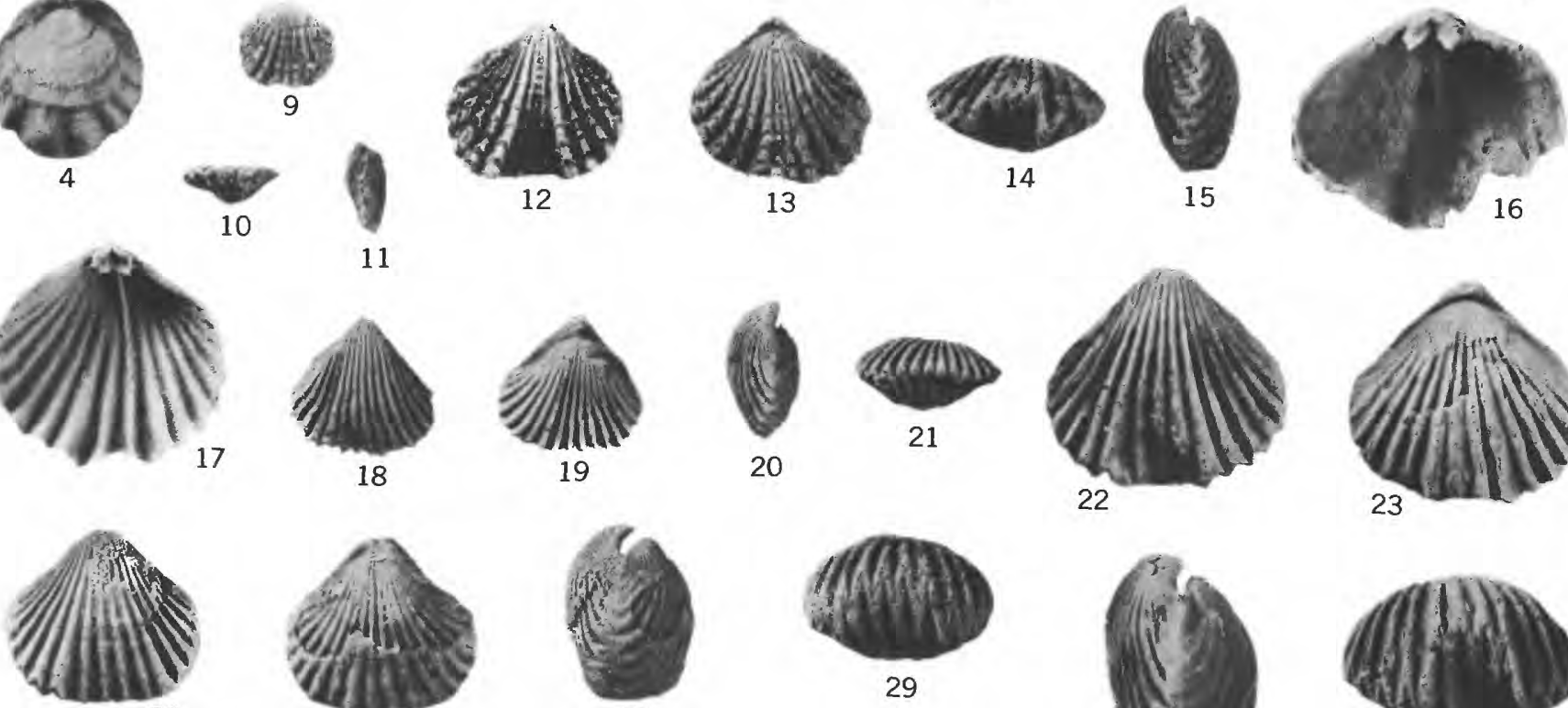

26
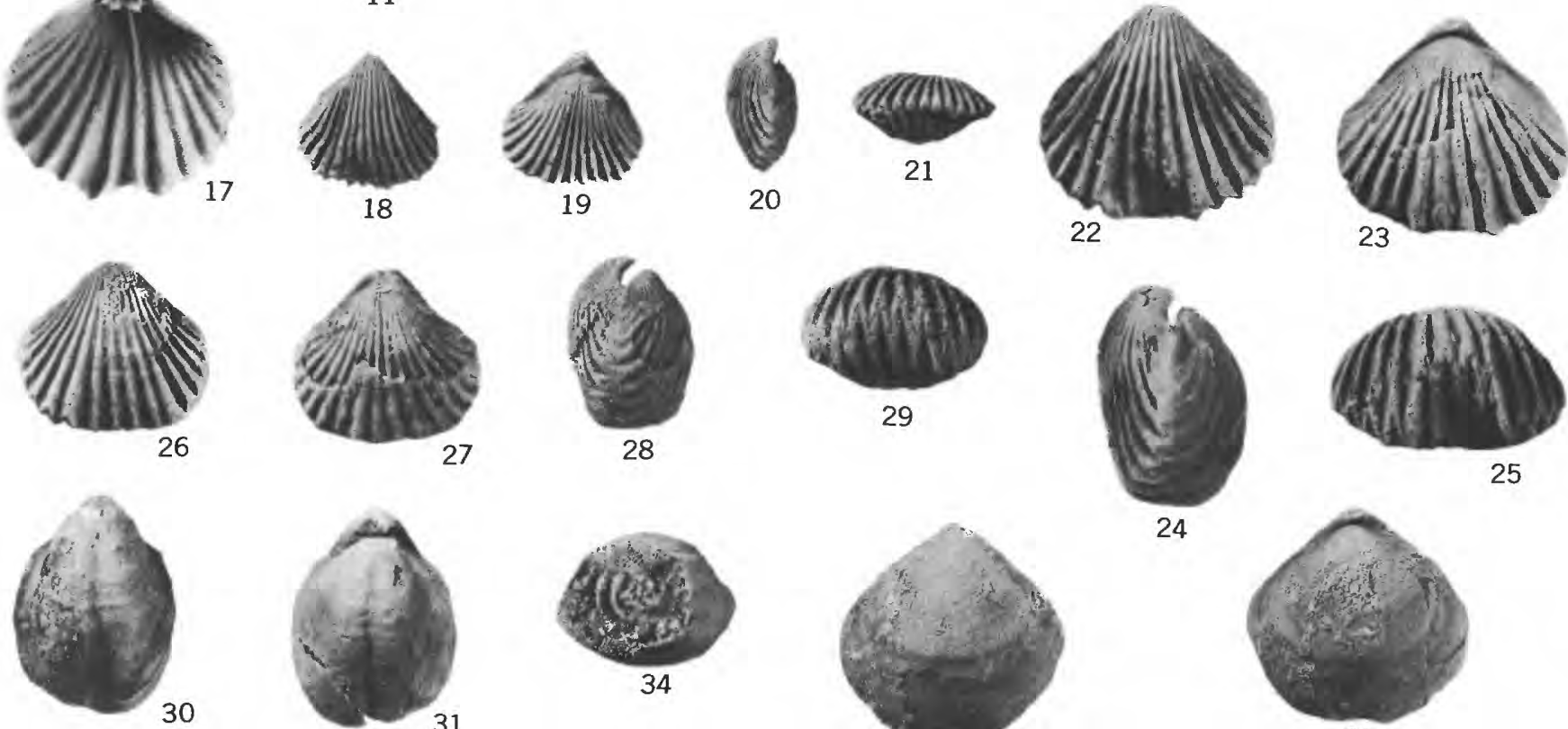

27
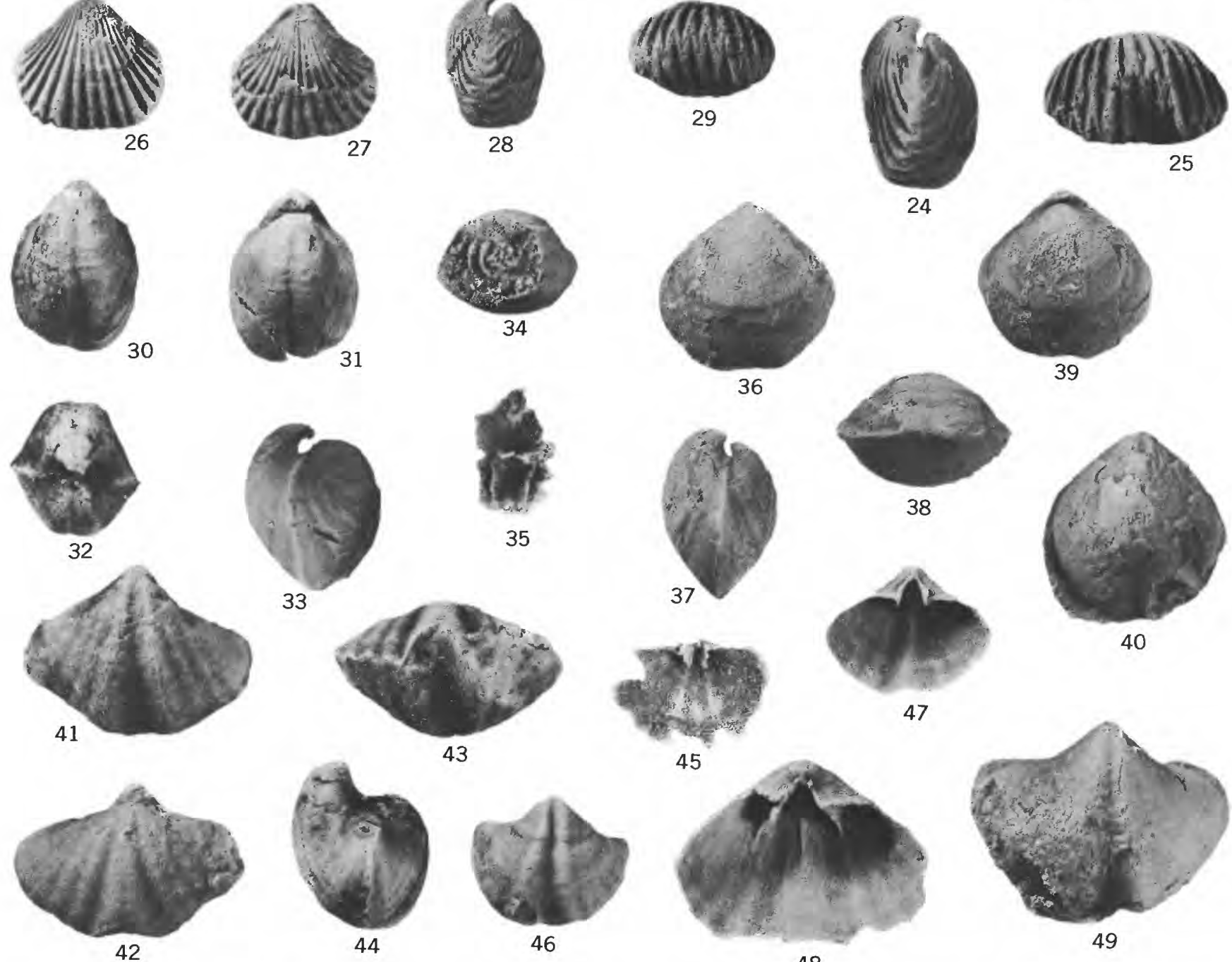

48
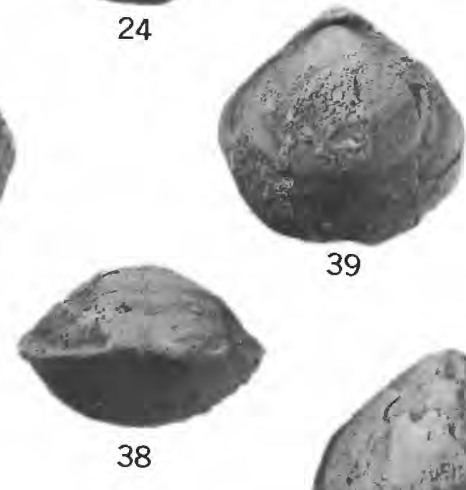

LANCEOMYONIA ?, MACHAERARIA ?, MICROSPHAERIDIORHYNCHUS, PROTATHYRIS , AND HOWELLELLA 


\section{PLATE 3}

[Figs. 31-34, $\times 5$; all others $\times 15$ ]

Figure 1. "Kloedenia" normalis Ulrich and Bassler (p. 25).

Lectotype, USNM 162287, one of syntypes numbered USNM 82997, from 182 feet above the base of the Wills Creek Shale, Flintstone, Md., according to original label with specimens. Presumably the same as specimen illustrated by Ulrich and Bassler, 1923, pl. 61, fig. 15.

2-10. Kloedeniopsis hartnageli n. gen., n. sp. (p. 26).

2. Small tecnomorphic right valve, paratype, YPM 23813; Shutter Corners, N.Y., YPM collection $5244 / 150$.

3, 4, 8. Right lateral, left lateral, and dorsal views of the holotype a tecnomorphic carapace, USNM 162285; Schoharie, N.Y., USGS collection 8063-SD.

5. Interior of a heteromorphic right valve, paratype, USNM 162286a, showing character of margins. Valve broken at posteroventral margin and with matrix in interior; Schoharie, N.Y., USGS collection 3393-SD.

6, 7. Left lateral and ventral views of a heteromorphic carapace, paratype, USNM 162286; Schoharie, N.Y., USGS collection 3393-SD.

9. Posterior view of a broken carapace, paratype, USNM 162286b, showing flangelike velar ridge; Shutter Corners, N.Y., USGS collection 3390-SD.

10. Right lateral view of heteromorphic valve, paratype, USNM 162286c; Schoharie, N.Y., USGS collection 8062-SD.

11. Welleriopsis? sp. (p. 29).

USNM 162291; Shutter Corners, N.Y., USGS collection 3390-SD.

12-17. Kloedeniopsis barretti (Weller) (p. 27).

12. Interior of tecnomorphic left valve, USNM 162289, showing marginal structures; Schoharie, N.Y., USGS collection 3393-SD.

13, 16. Ventral and oblique right lateral views of a heteromorphic carapace, USNM 162290, showing marginal spinules; Schoharie, N.Y., USGS collection 3393-SD.

14. Left lateral view of tecnomorphic carapace, YPM 23815; Schoharie, N.Y., YPM collection 5244/146.

15. Interior of heteromorphic right valve, USNM 162290a, showing hinge; Schoharie, N.Y., USGS collection 3393-SD.

17. Right lateral view of tecnomorphic carapace, USNM 162288, showing irregular reticulation; Schoharie, N.Y. USGS collection 8063-SD.

18-23. Welleriopsis? pustulosa n. sp. (p. 28).

18. Small tecnomorphic right valve, paratype, USNM 162294; Schoharie, N.Y., USGS collection 8063-SD.

19-21. Ventral, left lateral, and right lateral views of tecnomorphic carapace, holotype, USNM 162296; Schoharie, N.Y., USGS collection 3393-SD.

22, 23. Lateral and ventral views of heteromorphic left valve, paratype, USNM 162295; Schoharie, N.Y., USGS collection 8064-SD.

24-30. Tikiopsis denticulata n. gen., n. sp. (p. 27).

24. Dorsal view of complete carapace, paratype, YPM 23816, showing resemblance to Polynesian tiki; Schoharie, N.Y., YPM collection 5244/146.

25, 26. Ventral and right lateral views of complete carapace, holotype, USNM 162292; Schoharie, N.Y., US GS collection 3393-SD.

27. Lateral view of large right valve, paratype, YPM 23818; Shutter Corners, N.Y., YPM collection 5244/150.

28. Ventral view of broken carapace, paratype, YPM 23817, showing ventral flaps on both valves; Schoharie, N.Y., YPM collection 5244/146.

29. Ventral view of right valve showing flap, paratype, USNM 162293; Shutter Corners, N.Y., USGS collection 3390-SD.

30. Lateral view of small tecnomorphic left valve, paratype USNM 162292a; Schoharie, N.Y., USGS collection 8439-SD.

31-34. Leperditia scalaris (Jones) (p. 21).

31. Small left valve, USNM 162298, showing well-developed posterodorsal swelling; Aurelius Station, N.Y., USGS collection 3395-SD.

32. Left valve, USNM 162297, showing eye tubercle; Aurelius Station, N.Y., USGS collection 3395-SD.

33. Large right valve, USNM 162300, slightly corroded with acid, showing development of pustulose surface like that reported for Leperditia jonesi Hall and traces of adductor and chevron-shaped muscle scars; Aurelius Station, N.Y., USGS collection 3395-SD.

34. Large broken left valve, USNM 162301; Aurelius Station, N.Y., USGS collection 3395-SD. 
GEOLOGICAL SURVEY
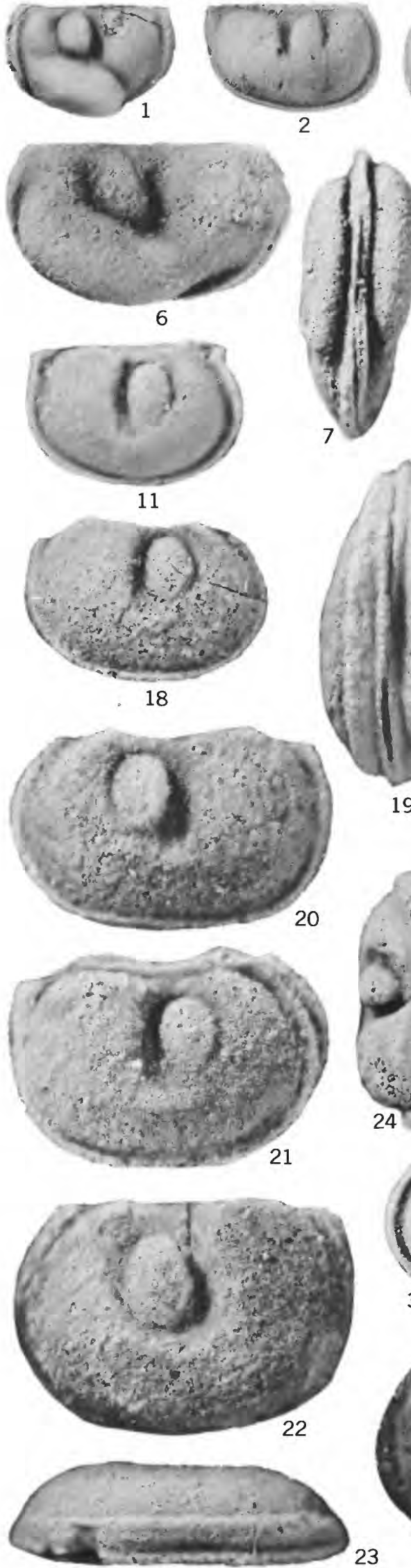

ROFESSIONAL PAPER 730 PLATE 3
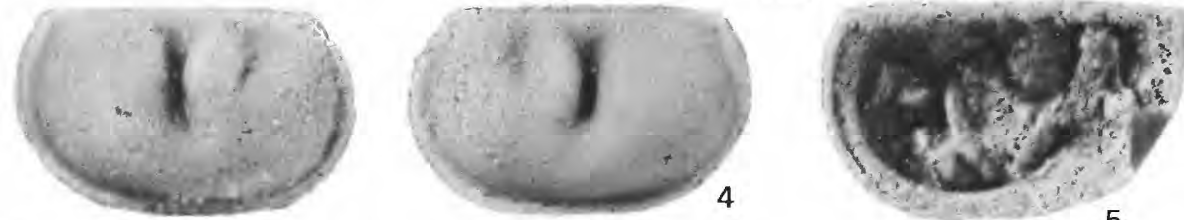

5

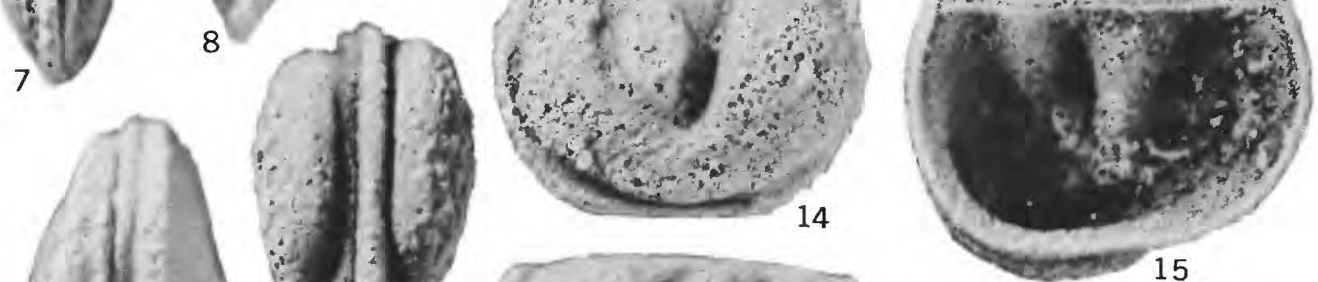

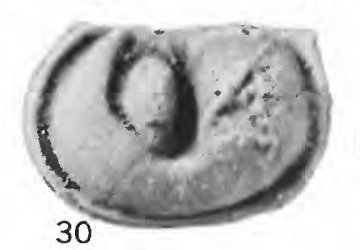
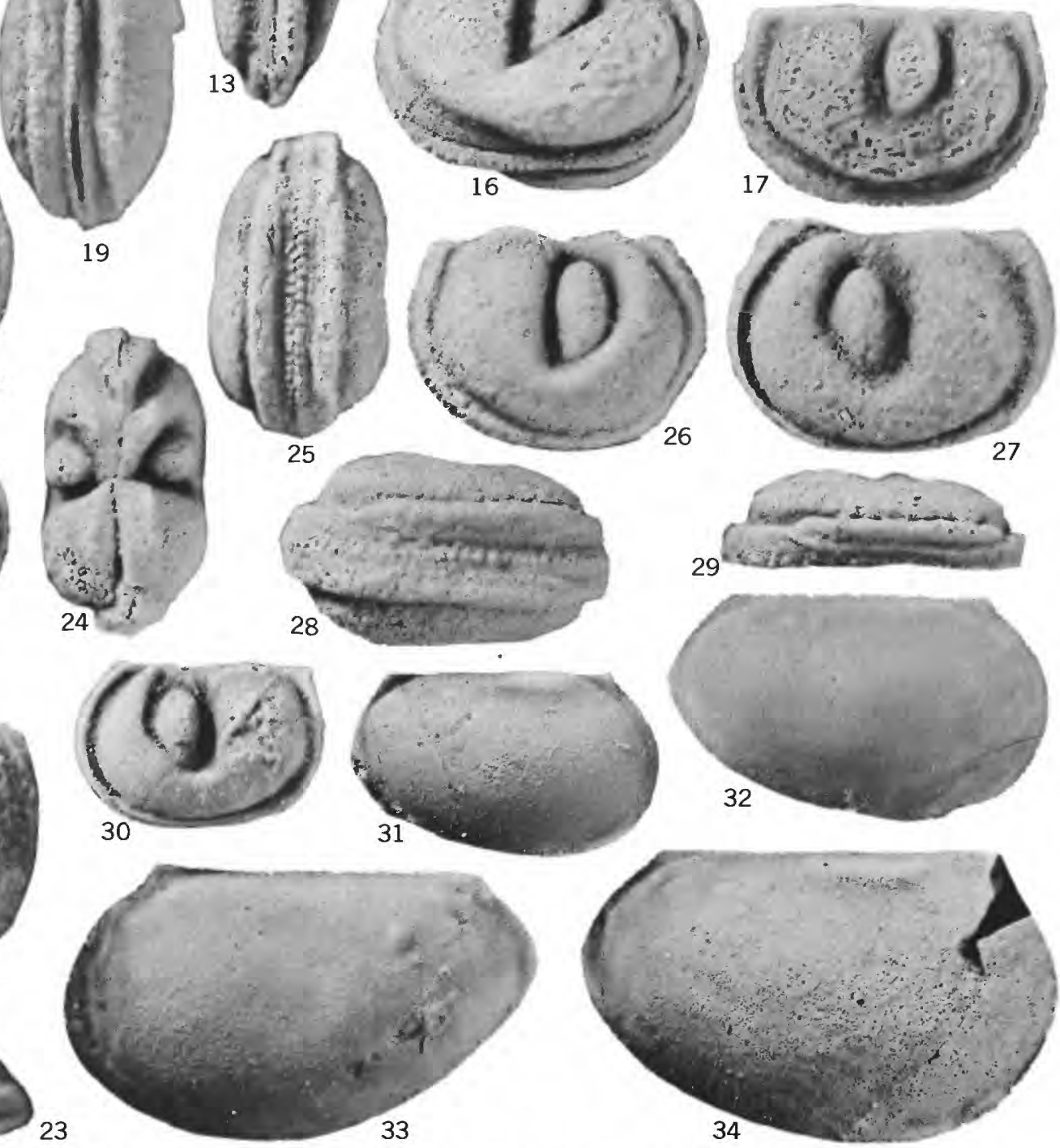

"KLOEDENIA," KLOEDENIOPSIS , WELLERIOPSIS ?, TIKIOPSIS , AND LEPERDITIA 


\section{PLATE 4}

[All figures $\times 30$ ]

Figures 1-8. Hammariella warthini n. sp. (p. 24).

1. Immature broken tecnomorphic left valve, paratype, USNM 162302; Schoharie, N.Y., USGS collection 7283SD. .

2. Tecnomorphic left valve showing cuspate anterior lobe, velum broken, paratype USNM 162303; Schoharie, N.Y., US GS collection 8062-SD.

3, 4. Lateral and ventral views of heteromorphic left valve, velum broken behind crumina, holotype, USNM 162304; Schoharie, N.Y., USGS collection 8062-SD.

5. Heteromorphic left valve showing character of velum behind crumina, anterior broken, paratype, USNM 162305; Schoharie, N.Y., USGS collection 8062-SD.

6. Tecnomorphic left valve, broken dorsally, showing velum, paratype, YPM 23819; Schoharie, N.Y., YPM collection 5244/146.

7. Heteromorphic right valve, broken, paratype, USNM 162306; Schoharie, N.Y., USGS collection 8062-SD.

8. Tecnomorphic left valve showing velum and broken anterior cusp, paratype, USNM 162307; Schoharie, N.X.. US GS collection 8062-SD.

9-12. Garniella concentrica n. sp. (p. 22).

9. Tecnomorphic right valve, paratype, YPM 23820; Schoharie, N.Y., YPM collection 5244/146.

10. Tecnomorphic left valve, paratype, YPM 23821; Jerusalem Hill, N.Y., YPM collection 2594.

11. Crushed heteromorphic carapace showing cristae on crumina, paratype, USNM 162308; Schoharie, N.Y., USGS collection 7283-SD.

12. Tecnomorphic left valve showing crista outlining median lobe, holotype, USNM 162309; Schoharie, N.Y., USGS collection 3393-SD.

13-22. Migmatella martinssoni n. gen., n. sp. (p. 22).

13. Right lateral view of crushed tecnomorphic carapace showing cristate lobes and narrow velar bend, paratype YPM 23822; Schoharie, N.Y., YPM collection 5244/146.

14. Tecnomorphic left valve showing velum reduced to velar bend posteriorly, paratype, YPM 23823; Jerusalem Hill, N.Y., YPM collection 2594.

15. Right lateral view of small tecnomorphic carapace showing velar bend, paratype, USNM 162310; Shutter Corners, N.Y., USGS collection 3390-SD.

16. Oblique ventral view of broken heteromorphic left valve showing velar spur and trace of velum across crumina, paratype, USNM 162311; Schoharie, N.Y., USGS collection, 3393-SD.

17. Lateral view of heteromorphic right valve showing absence of velar spur, paratype, USNM 162312; Schoharie, N.Y., US GS collection 3393-SD.

18. Lateral view of tecnomorphic right valve,paratype, USNM 162313; Schoharie, N.Y., US GS collection 3393-SD.

19-21. Dorsal, left lateral, and ventral views of a complete carapace, holotype, USNM 162314; Schoharie, N.Y., US GS collection 8063-SD.

22. Heteromorphic left valve, paratype, YPM 23824; Schoharie, N.Y., YPM collection 5244/146.

23-28. Dibolbina reticruminata n. sp. (p. 23).

23. Tecnomorphic right valve, velum and both cardinal angles broken, paratype, USNM 162315; Shutter Corners, N.Y., USGS collection 3390-SD.

24. Tecnomorphic left valve, velum and part of syllobium broken, paratype, USNM 162316; Schoharie, N.Y., USGS collection 8062-SD.

25 , 26. Ventral and lateral views of heteromorphic left valve, velum partly broken, showing torus, paratype, USNM 162317; Schoharie, N.Y., USGS collection 7283-SD.

27. Ventral view of a complete heteromorphic carapace showing velum extending around crumina and torus not crossing crumina, paratype, YPM 23825; Schoharie, N.Y., YPM collection 5244/146.

28. Dorsal view of complete heteromorphic carapace, velum slightly broken posteriorly, holotype, YPM 23826; Schoharie, N.Y., YPM collection 5244/146. 
GEOLOGICAL SURVEY
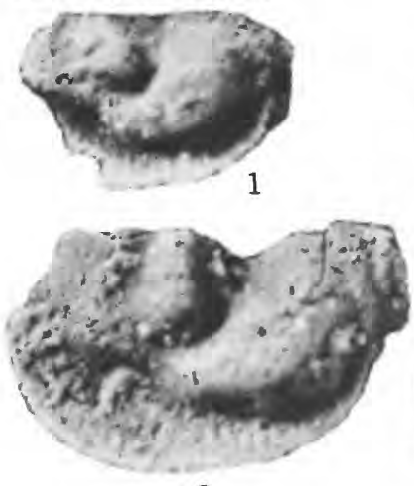

6
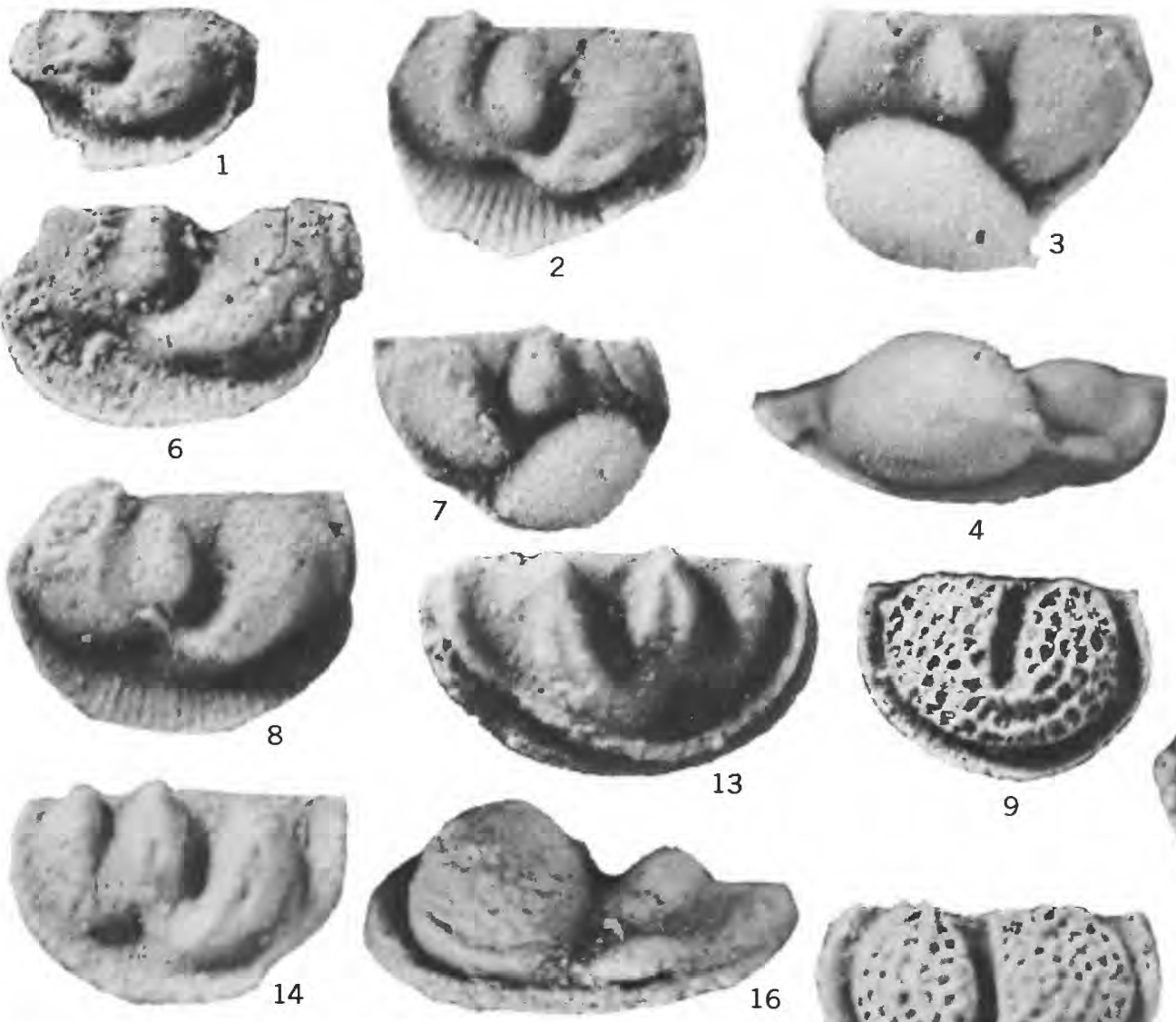

PROFESSIONAL PAPER 730 PLATE 4
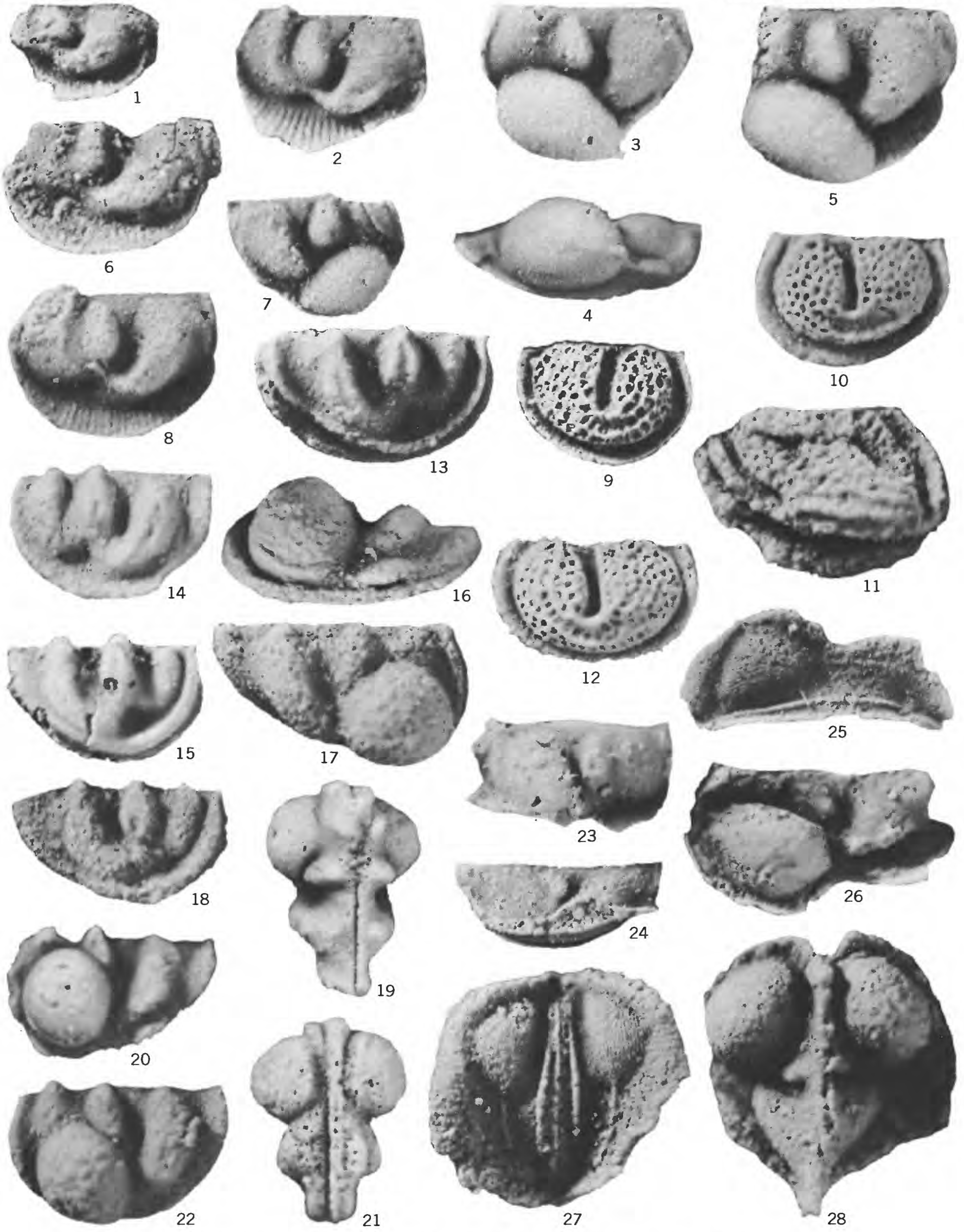

HAMMARIELLA , GARNIELLA , MIGMATELLA, AND DIBOLBINA 


\section{PLATE 5}

[All figures $\times 30$ ]

Figures 1-12. Dizygopleura monostigma n. sp. (p. 34).

1, 2. Right lateral and left lateral views of small tecnomorphic carapace, about A-3, USNM 162318; Schoharie, N.Y., USGS collection 3393-SD.

3. Left lateral view of small tecnomorphic carapace showing tendency for ventral pit to connect with S3, USNM 162319; Schoharie, N.Y., USGS collection 3393-SD.

4. Left lateral view of small carapace, about A-3, paratype, USNM 162320; Keyser Limestone, just above Gypidula prognostica Zone, La Vale, Md., USGS collection 8125-SD.

5, 6. Right and left lateral views of tecnomorphic carapace, A-2, USNM 162321; Schoharie, N.Y., USGS collection 3393-SD.

7, 8. Right lateral and dorsal views of tecnomorphic carapace showing stragular process, about A-2, USNM 162322; Schoharie, N.Y., USGS collection 3393-SD.

9-11. Dorsal, left lateral and right lateral views of adult tecnomorph, holotype, USN M 162323; Keyser Limestone, just above Gypidula prognostica, Zone, La Vale, Md., USGS collection 8125-SD.

12. Heteromorphic left valve showing broader L4, paratype, USNM 162324; Keyser Limestone, just above Gypidula prognostica Zone, La Vale, Md., USGS collection 8125-SD.

13-16. Dizygopleura costata Ulrich and Bassler (p. 35).

13. Left lateral view of lectotype, USNM 162325; Tonoloway Limestone (upper), Keyser, W. Va., from cotype lot USNM 63677.

14, 15. Left and right lateral views of a carapace, USNM 162326; Schoharie, N.Y., USGS collection 3393-SD.

16. Dorsal view of another carapace, USNM 162327; Schoharie, N.Y., USGS collection 3393-SD.

17. Dizygopleura clarkei paupera (Ulrich and Bassler) (p. 34).

Right lateral view of carapace, holotype, USNM 53280; Keyser Limestone, Cumberland, Md.

18, 19. Dizygopleura viafontinalis n. sp. (p. 36).

18. Right lateral view of slightly crushed tecnomorphic carapace, paratype, USNM 162328; Schoharie, N.Y., USGS collection 3393-SD.

19. Lateral view of heteromorphic left valve, holotype, showing sigmoidal S1 and punctate surface, USNM 162329; Schoharie, N.Y., USGS collection 8062-SD.

20-45. Dizygopleura hallii (Jones) (p. 31).

20. Interior of right valve showing stragular notch, USNM 162330; Schoharie, N.Y., US GS collection 8063-SD.

21,22 . Right and left lateral views of small tecnomorphic carapace, A-4 or A-3, USNM 162331; Schoharie, N.Y., USGS collection 3393-SD.

23. Right lateral view of small tecnomorphic carapace, A-3 or A-4, USNM 162332; Schoharie, N.Y., USGS collection 3393-SD.

24, 25. Right and left lateral views of a slightly crushed tecnomorphic carapace, A-3, USNM 162333; Schoharie, N.Y., USGS collection 3393-SD.

26, 27. Right and left lateral views of a carapace with narrow but deep S3, A-3, USNM 162334; Schoharie, N.Y., USGS collection 3393-SD.

28 , 29. Right and left lateral views of a tecnomorphic carapace with wider S3, A-3, USNM 162335; Schoharie, N.Y., USGS collection 3393-SD.

30. Left lateral view of tecnomorphic carapace with narrow, shallow S3, A-3, USNM 162336; Schoharie, N.Y., US GS collection 3393-SD.

31. Left lateral view of tecnomorphic carapace with narrow S3, A-2, USNM 162337; Schoharie, N.Y., USGS collection 3393-SD.

32. Right lateral view of tecnomorphic carapace with narrow S3, A-2 or A-1, USNM 162338; Schoharie, N.Y. USGS collection 3393-SD.

33. Right lateral view of tecnomorphic carapace with wide S3, A-1, USNM 162339; Schoharie, N.Y., USGS collection 3393-SD.

34, 35. Right and left lateral views of tecnomorphic carapace, A-1, USNM 162340; Schoharie, N.Y., USGS collection 3393-SD.

36. Left lateral view of tecnomorphic carapace, A-1, YPM 23827; Schoharie, N.Y., YPM collection 5244/146.

37, 38. Right and left lateral views of tecnomorphic carapace with wide and deep S3, adult, USNM 162341; Schoharie, N.Y., USGS collection 3393-SD.

39. Dorsal view of adult tecnomorphic carapace showing stragular process, USNM 162342; Schoharie, N.Y., USGS collection 3393-SD.

40. Dorsal view of adult heteromorphic carapace showing posterior inflation, USNM 162343; Schoharie, N.Y., USGS collection 3393-SD.

41. Left lateral view of adult tecnomorphic carapace with deep sulci, USNM 162344; Schoharie, N.Y., USGS collection 3393-SD.

42. Left lateral view of adult heteromorphic carapace, USNM 162345; Schoharie, N.Y., USGS collection 3393SD.

43. Right lateral view of slightly crushed heteromorphic carapace, NYSM 12718; from slab with holotype of Dizygopleura clarkei, from Herkimer County, N.Y.

44. Lateral view of heteromorphic left valve, holotype of Dizygopleura clarkei, NYSM 4141; Herkimer County, N.Y.

45. Lateral view of heteromorphic left valve, holotype of Dizygopleura hallii, BMNH In 35128 ; near Utica, N.Y. 

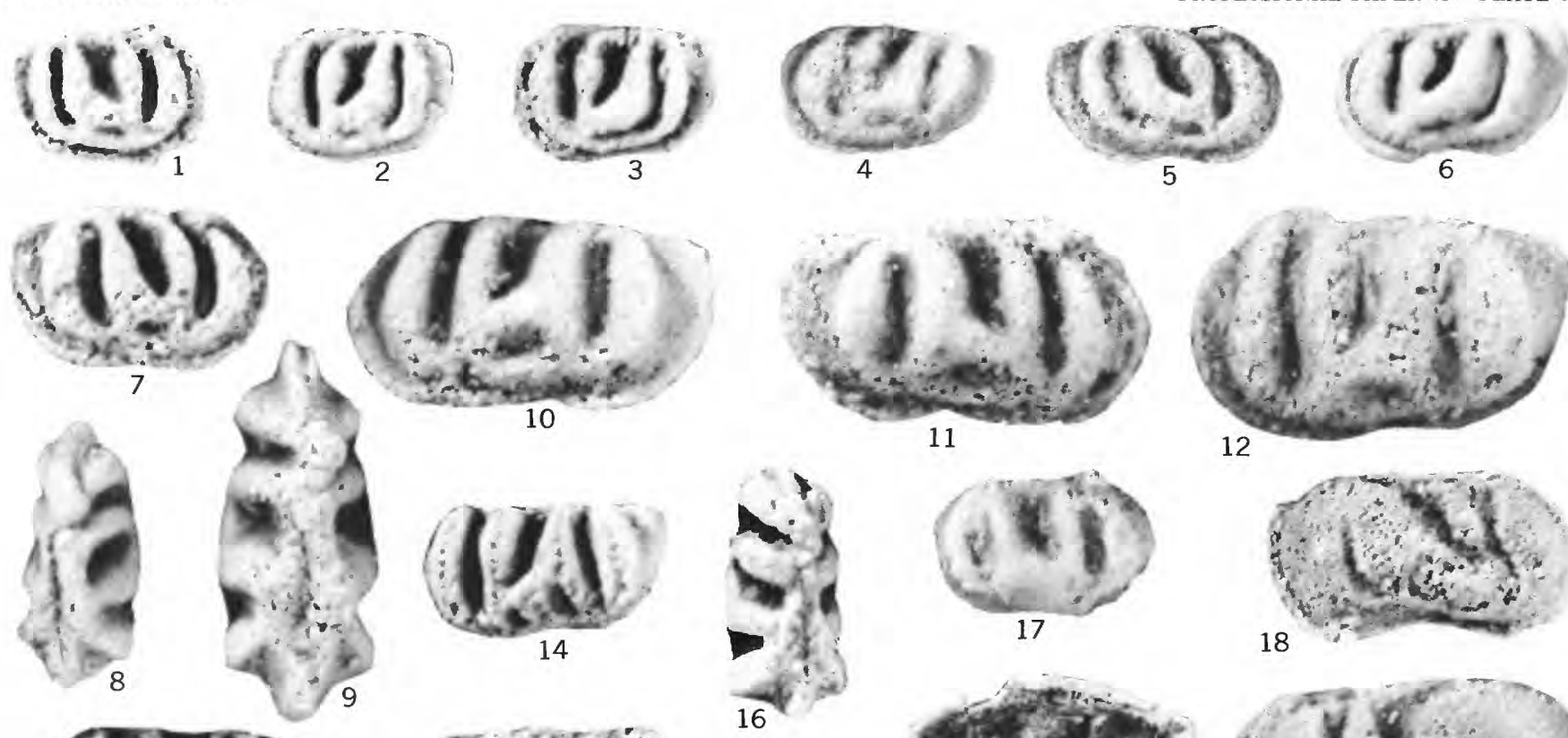

11

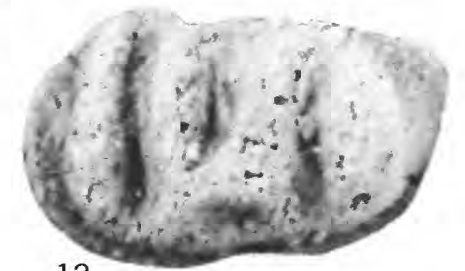

12
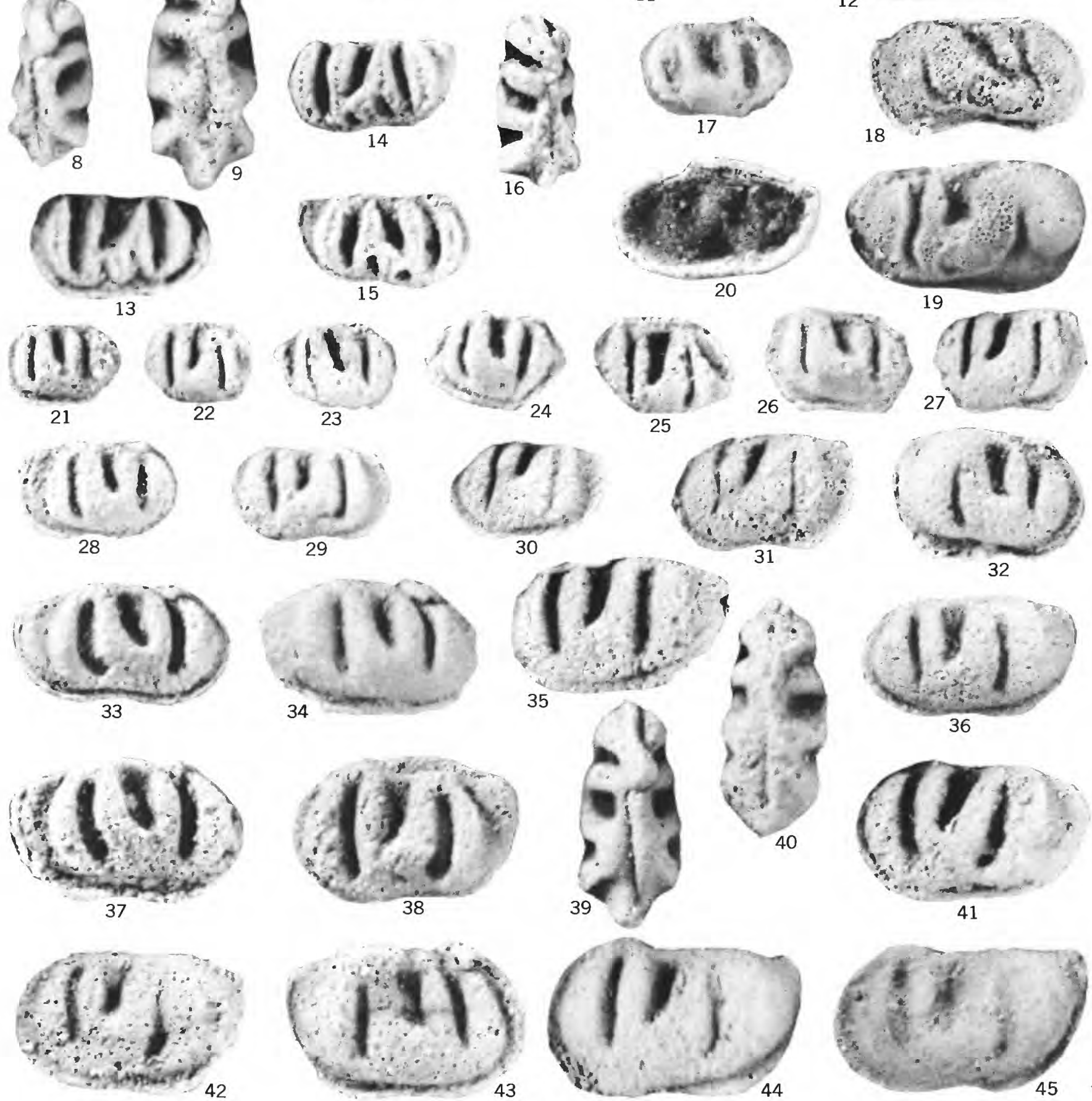


\section{PLATE 6}

[All figures $\times 30$ ]

Figures 1-3. Thlipsurella parva n. sp. (p. 39).

1, 2. Right lateral and dorsal views of the holotype, USNM 162346; Schoharie, N.Y., USGS collection 7283- SD.

3. Left lateral view of paratype carapace, USNM 162347; Schoharie, N.Y. USGS collection 7283-SD.

4-7. Thlipsuropsis inaequalis (Ulrich and Bassler) (p. 38).

4, b. Dorsal and right lateral views of a complete carapace, YPM 23828; Schoharie, N.Y., YPM collection 5244 / 146.

6, 7. Left lateral and dorsal views of another complete carapace, USNM 162348; Schoharie, N.Y., USGS collection 3393-SD.

8-13. Nunculina striatopuncta n. gen., n. sp. (p. 41).

8. Interior of left valve, paratype, USNM 162349, showing slight marginal groove; Schoharie, N.Y., USGS collection 7283-SD.

9. Dorsal view of complete carapace, paratype, USNM 1623b0; Schoharie, N.Y., USGS collection 3393-SD.

10. Left lateral view of carapace, slightly broken posteriorly, showing small punctae, paratype, USNM 162351; Schoharie, N.Y., USGS collection 7283-SD.

11. Interior of left valve showing internal ridge reflecting external sulcus, paratype, YPM 23829; Schoharie, N.Y., YPM collection 5244/146.

12. Right lateral view of carapace showing overlap, holotype, YPM 23830; Schoharie, N.Y., YPM collection $5244 / 146$.

13. Left lateral view of large carapace, paratype, YPM 23831; Schoharie, N.Y., YPM collection 5244/146.

14. Hollinid?, gen. and sp. indet. (p. 29). USNM 162353; Schoharie, N.Y., US GS collection 8064-SD.

15. Kirkbyellid?, gen. and sp. indet. (p. 29). USNM 162354; Schoharie, N.Y., USGS collection 8064-SD.

16. Halliella? sp. (p. 30). USNM 162355; Schoharie, N.Y., USGS collection 7283-SD.

17. Marginia? sp. (p. 38). USNM 162356; Schoharie, N.Y., USGS collection 8062-SD.

18-24. Cytherellina crepiduloides n. sp. (p. 39).

18. Right lateral view of complete carapace, holotype, USNM 162357; Schoharie, N.Y., USGS collection 3393SD.

19. Interior of left valve showing anterodorsal shelf and round depression below it, presumably adductor muscle pit, paratype YPM 23832; Schoharie, N.Y., YPM collection 5244/146.

20. Interior of right valve showing lack of marginal structures, paratype, YPM 23833; Schoharie, N.Y., YPM collection 5244/146.

21. Interior of right valve showing adductor muscle pit, paratype, USNM 162358; Schoharie, N.Y., USGS collection 3393-SD.

22. Dorsal view of complete carapace, paratype, YPM 23834; Schoharie, N.Y., YPM collection 5244/146.

23. Interior of left valve showing marginal structures, paratype, YPM 23835; Schoharie, N.Y., YPM collection $5244 / 146$.

24. Right lateral view of crushed carapace, paratype, YPM 23836; Schoharie, N.Y., YPM collection 5244/146. 25-29. Eukloedenella? weldae n. sp. (p. 37).

25. Left lateral view of complete tecnomorphic carapace, paratype, USNM 162359; Schoharie, N.Y., USGS collection 7283-SD.

26. Dorsal view of complete tecnomorphic carapace showing indented posterior, paratype, USNM 162360; Schoharie, N.Y., USGS collection 7283-SD.

27. Right lateral view of heteromorphic carapace, holotype, USNM 162361; Schobarie, N.Y., USGS collection 3393-SD.

28. Dorsal view of complete heteromorphic carapace showing wide stragular process and inflated posterior, paratype USNM 162362; Schoharie, N.Y., USGS collection 7283-SD.

29. Interior of large heteromorphic left valve showing groove beneath stragular process and possible adductor muscle pit, paratype, USNM 162363; Schoharie, N.Y., USGS collection 3393-SD.

30-33. Bonneprimites? breviformis Swartz and Whitmore (p. 38).

Dorsal, left lateral, ventral, and right lateral views of a complete carapace, USNM 162364; Shutter Corners, N. Y., USGS collection 3390-SD.

34-40. Leiocyamus punctatus n. sp. (p. 29).

34. Interior of heteromorphic left valve, paratype, YPM 23837; Schoharie, N.Y., YPM collection 5244/146.

35. Interior of heteromorphic right valve, showing hinge, paratype, YPM 23838; Schoharie, N.Y., YPM collection $5244 / 146$.

36. Dorsal view of tecnomorphic carapace, paratype, USNM 162365; Schoharie, N.Y., USGS collection 3393-SD.

37. Right lateral view of tecnomorphic carapace, paratype, YPM 23839; Schoharie, N.Y., YPM collection $5244 / 146$

38. Posterior view of heteromorphic carapace, paratype, USNM 162366; Schoharie, N.Y., USGS collection 3393-SD

39. Left lateral view of heteromorphic carapace, holotype, YPM 23840; Schoharie, N.Y., YPM collection $5244 / 146$.

40. Dorsal view of heteromorphic carapace, paratype, YPM 23841; Schoharie, N.Y., YPM collection 5244/146. 


\section{Plate 6-Continued}

41-43. Kloedenella sp. (p. 37).

41, 42. Right and left views of a tecnomorphic carapace, USNM 162367; Schoharie, N.Y., USGS collection 3393-SD.

43. Right lateral view of another tecnomorphic carapace, YPM 23842; Schoharie, N.Y., YPM collection $5244 / 146$.

44. Primitiopsis? sp. (p. 30).

Left lateral view of slightly broken tecnomorphic carapace, USNM 162368; Schoharie, N.Y., USGS collection 8062-SD.

45, 46. Leiocyamus sp. B (p. 30).

45. Right lateral view of crushed heteromorphic carapace, USNM 162369; Schoharie, N.Y., USGS collection 3393-SD.

46. Left valve of heteromorph, USNM 162370; Schoharie, N.Y., USGS collection 3393-SD.

47, 48. Leiocyamus sp. A (p. 30).

Oblique dorsal and left lateral views of heteromorphic carapace, YPM 23843; Shutter Corners, N.Y., YPM collection $5244 / 150$. 

GEOLOGICAL SURVEY
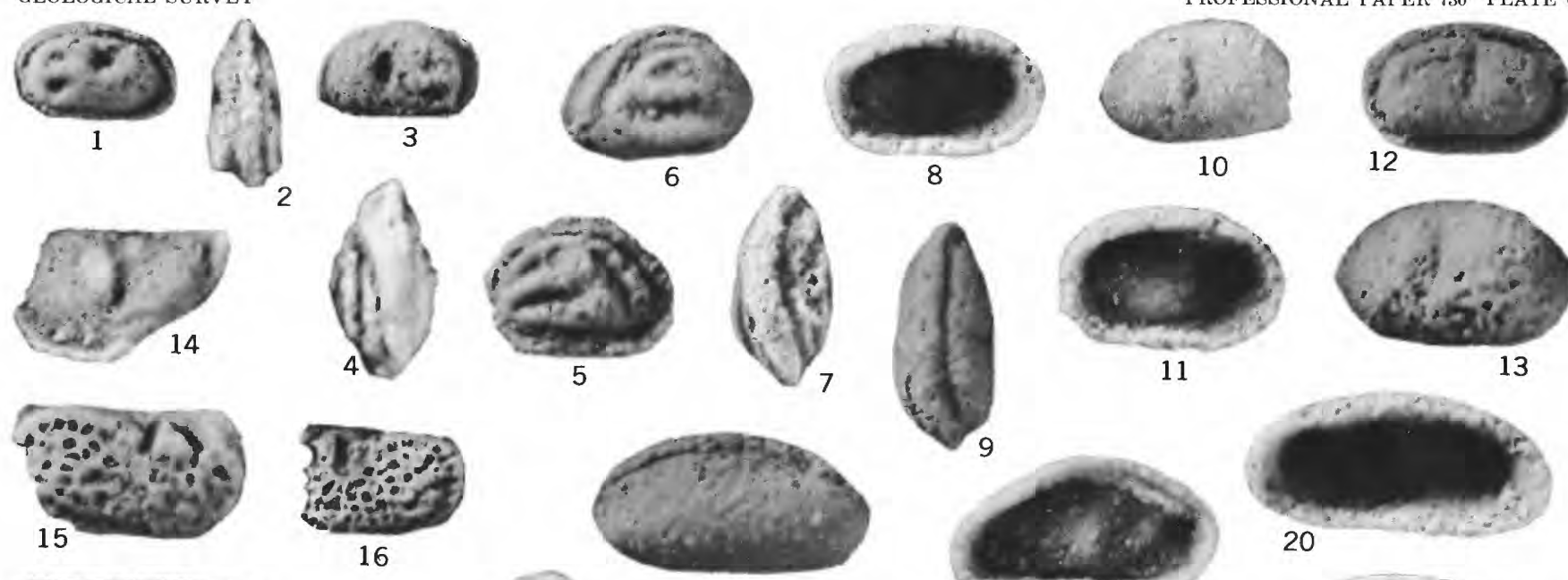

11
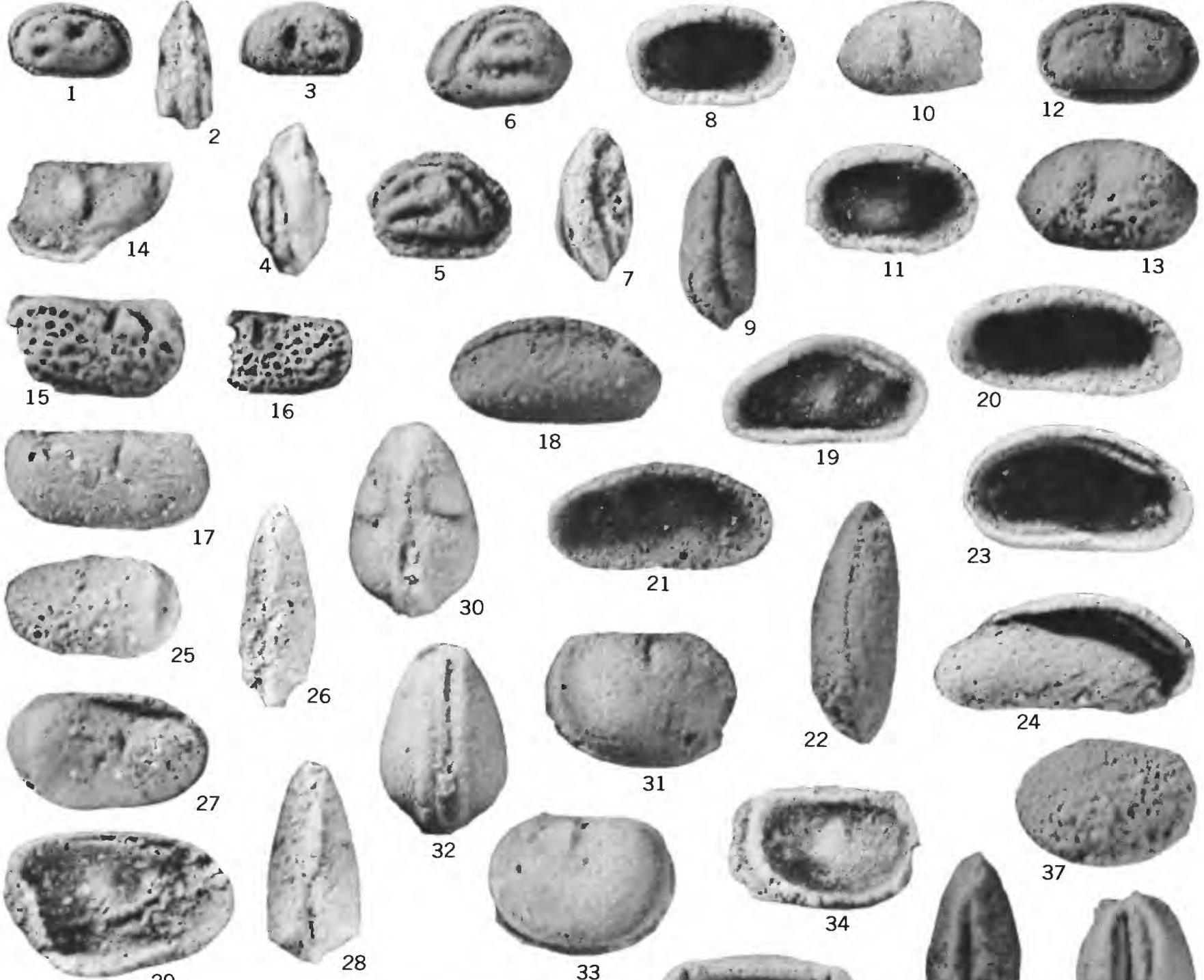

18
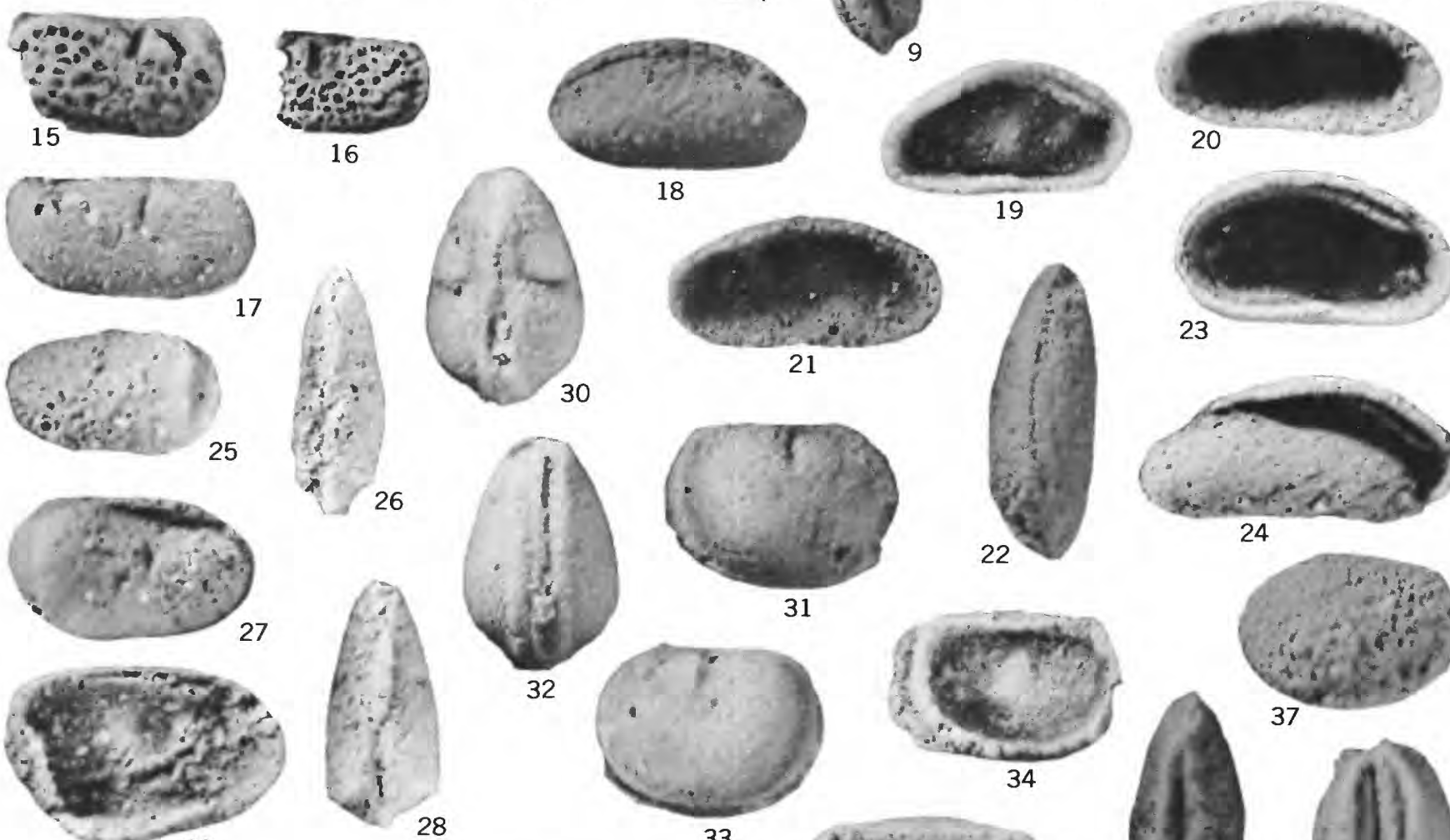

29
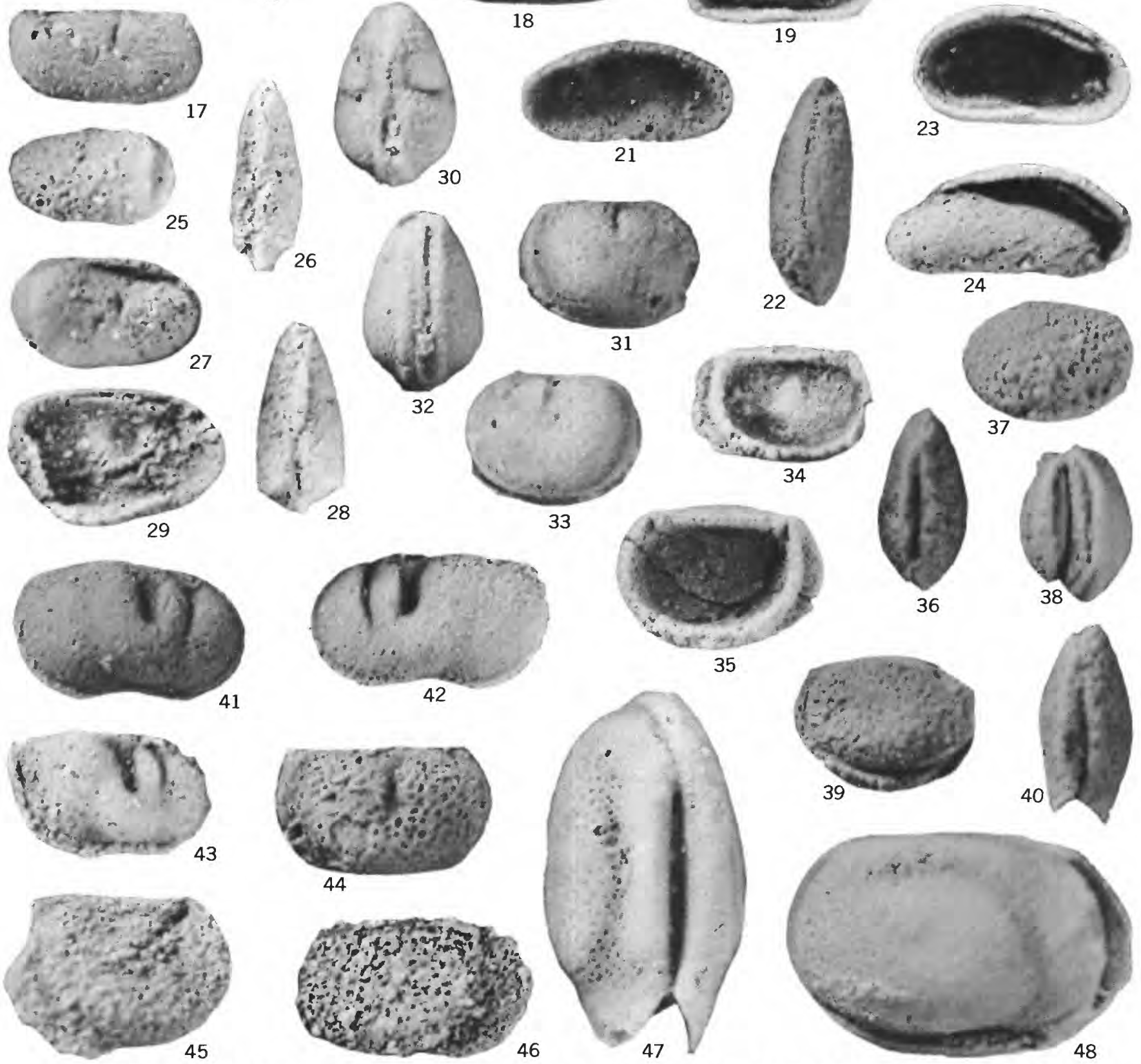

THLIPSURELLA , THLIPSUROPSIS , NUNCULINA , HOLLINID?, KIRKBYELLID?, HALLIELA ?, MARGINIA ?, CYTHERELLINA, EUKLOEDENELLA ?, BONNEPRIMITES?, LEIOCYAMUS, KLOEDENELLA, AND PRIMITIOPSIS? 